\title{
The Reality of Return: Exploring the Experiences of World War One Soldiers after their Return to New Zealand
}

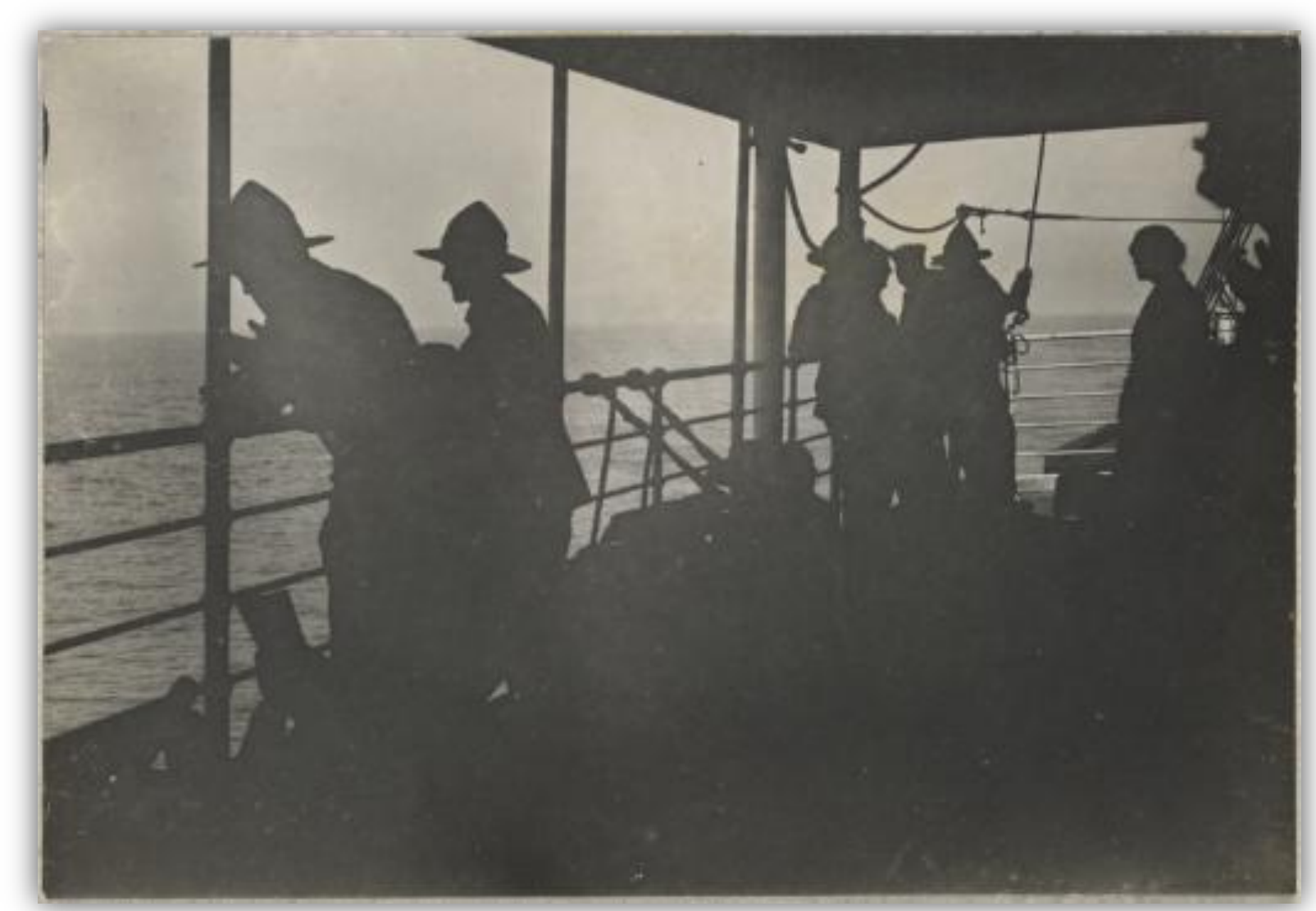

Coralie Clarkson

A thesis submitted to Victoria University of Wellington in fulfilment of the requirements for the degree of Master of Arts in History

Victoria University of Wellington 


\section{Table of Contents}

Abstract ii

Acknowledgements

Abbreviations

Introduction 1

Chapter One Dreaming of Home, Returning Home, and Making a Go of it 24

Chapter Two Employment and Soldier Settlement 55

$\begin{array}{ll}\text { Chapter Three Alcoholism } & 93\end{array}$

$\begin{array}{ll}\text { Chapter Four Tuberculosis } & 119\end{array}$

$\begin{array}{lr}\text { Conclusion } & 138\end{array}$

$\begin{array}{ll}\text { Bibliography } & 145\end{array}$

Cover Photo: 'Troops on board the Tainui, leaving England for New Zealand after World War I', 8 August 1919, by Frederic Kingsford.

Ref: PA1-0-934-062-3, in Kingsford, Frederic, 1890-1965 :Photograph album of views of England, Ireland, voyage to New Zealand after World War I, PA1-0-934, Alexander Turnbull Library, Wellington. 


\section{Abstract}

The focus of this thesis is the lives of New Zealand's returned Great War soldiers. This thesis explores the experiences of men who did not successfully repatriate as a counterpoint to the experiences of those who did, and argues that men's return to New Zealand and their post war lives were shaped by many factors including access to employment and good health. Many returned soldiers were able to resume their lives on return and led relatively happy and successful lives. For these men, their success seems to have come from the ability to find or resume employment, good health, family support, and financial support. For those who did not, one or more of these factors was often missing, and this could lead to short or long term struggle.

The 1920s form the backdrop of this thesis, and were a time of uncertainty and anxiety for returned men and their families. The disillusionment of the 1920s was exacerbated by men's nostalgia for New Zealand which they built up during the war. Tens of thousands of men returned to New Zealand from war with dreams and hopes for the future. The horrors of war had given men an idealistic view of peaceful New Zealand, and dreams of home comforts and loved ones had sustained these men through their long absence. For those who returned to find life difficult, the idealistic view of New Zealand as a land of simplicity and happiness would have been hard to maintain.

Chapter 1 demonstrates the idealisation of New Zealand and 'home' built up by soldiers and their families during the war. Chapters 2, 3 and 4 use the lenses of employment, illness - specifically tuberculosis - and alcoholism to argue that for many men and their families, the 1920s were an extension of the anxieties and separation of the Great War years. Sadly, for some, their lives were forever marred by the spectre of war and what their absence from home cost them. 


\section{Acknowledgements}

Over the course of this thesis I have had assistance and guidance from many people, without which this project would not have been possible.

Firstly, thanks must go to my supervisor, Kate Hunter, who has generously given her time and knowledge to this project. Her assistance and guidance was invaluable and helped me to think outside the square. I also gratefully acknowledge the assistance of Jim McAloon and Evan Roberts.

I must also acknowledge the staff of the National Library and Archives New Zealand for their assistance during this project, along with the Ministry of Health for allowing me access to restricted archives related to Tuberculosis. I also thank Nicholas Boyack and Jane Tolerton for allowing me the use of the World War I Oral History collection, a valuable resource.

Thanks go to the History Department for providing a comfortable working environment, along with the support of my fellow post-graduate students. Special thanks go to my family and friends, whose love and support have helped and encouraged me in many ways throughout my time writing this thesis.

Lastly, thanks to Leigh for his patience, love, support, and encouragement. 


\section{Abbreviations}

AG Ashburton Guardian

ATL Alexander Turnbull Library

CST Colonist

EP Evening Post

HNS Hawera \& Normanby Star

ME Marlborough Express

NZT New Zealand Truth

PBH Poverty Bay Herald 


\section{Introduction}

Soldiers returning to New Zealand from World War I had varying experiences. For some, the war did not have a long lasting effect on them; they were able to return to jobs, resume or start family life, and come to terms with their war experiences without much outward difficulty. However, for others, their homecoming was the beginning of an uncertain time in their life. Inability to secure employment, difficulty and failure on soldier settlements, illness and addiction were just a few of the many issues that plagued some returned men. Some soldiers' attempts to make a life for themselves suffered many setbacks. All of these private struggles were taking place at a time that held many uncertainties in itself. The 1918 flu epidemic which killed thousands was a cruel addendum to a war that had already taken so many lives; returned men were affected, with some receiving the news that their relatives had died from this illness, or becoming ill themselves. Lieutenant Charles Bayly received news at the front that his wife had died of influenza on 10 November 1918, a heavy blow to bear at a time when the war was drawing to an end and dreams of returning home would become reality. ${ }^{1}$ Meanwhile, a returned soldier, Charles Rowson, died on 8 November from influenza. ${ }^{2}$ Both deaths occurred at home, a place thought to be safe from widespread death.

Soldiers were not the only people dealing with uncertainty. Anxiety over the return of soldiers to New Zealand became apparent in the media, and the various problems associated with this became known as 'the returned soldier problem' in the New Zealand press. It is worth considering why there was a fear of returning men, and it is obvious when looking at the use of the term 'returned soldier problem' that it was

\footnotetext{
${ }^{1}$ Graham Hucker, 'The Armistice: Responses, Understandings and Meanings for a Rural Region', in John Crawford \& Ian McGibbon (eds.), New Zealand's Great War, Auckland, 2007, p.574.

${ }^{2}$ Hucker, 'The Armistice', p.574.
} 
often used in specific contexts. This term encompassed any problem concerning returning soldiers but was mostly related to soldier unemployment. However, some newspaper articles do concern other matters. One such article in April 1918, entitled 'Returned Soldier Problem', describes the actions of a returnee who stole and pawned the jewellery of a woman who had taken him in on his return. ${ }^{3}$ The article clearly identified the man as a returned soldier, allowing for worry over what would happen when men returned en masse. Indeed, the idea of the idle, single and unemployed returned soldier seems to underpin the phrase 'returned soldier problem'. Such a soldier would become dependent on others, and would not be a useful or productive member of society. The government's efforts in repatriating soldiers showed their desire to prevent this happening, however many men were for various reasons dependent on others despite their efforts. This was inevitable when considering what these men faced at war and the hardships some faced on return.

The backdrop to soldiers' experiences in the 1920 s is what historians have argued was a 'reaffirmation of the domestic', an increased move towards familial security and attachment to the ideals of private life, and in this an increased desire for stability. ${ }^{4}$ For men returning from war, this meant that there was a renewed importance in familial and romantic relationships. For many, a desire to settle down and create their families was strong; the idealistic writings of men from the front were often directed at fiancées at home, predicting their post-war lives. It is doubtful that many of these predictions and dreams came true for returned men, and for those who faced added difficulties through employment, settlement, illness or addiction, the security of the family unit could be shattered in many ways. New Zealand's historians

\footnotetext{
${ }^{3} N Z T, 13$ April 1918, p.6.

${ }^{4}$ Tammy Proctor, On My Honour: Guides and Scouts in interwar Britain, Philadelphia, 2002, p.2.
} 
of the war's aftermath do not use evidence of wartime experiences, such as men's letters, to illuminate the various expressions of hopefulness and plans for the future that soldiers sent home the war. ${ }^{5}$ Yet these expressions speak to the desire for domestic life. Tammy Proctor argues that 'intimate relationships and family life seem a likely enough retreat for the emotionally scarred men and women of the war generation', and Cynthia Commachio notes that the 1921 Canadian census 'revealed more married Canadians than any time on record', and states that 'the family was resilient ${ }^{6}{ }^{6}$ While being a retreat, the effects that emotionally scarred returned men had on their families is another consideration that needs to be made. Many women and their families had to cope with, and 'absorb' the trauma of men's war experiences and the pain and frustration they felt at their post-war lives. ${ }^{7}$ Furthermore, the assault on masculine ideals that some post-war circumstances could bring may have led to strain in these men's relationships. The strength of the breadwinner ideal was also psychological, and failure to provide was seen as an indication of 'failed manhood' ${ }^{8}$

In this thesis I argue New Zealand soldiers' experiences of war and separation from loved ones led them to romanticise their past and future lives in New Zealand. Their letters demonstrate that their futures preoccupied them while they were on active service. These dreams centred on reunion with loved ones and thoughts of future employment. The dreams that some men had for their post-war lives did not

\footnotetext{
${ }^{5}$ Gwen Parsons, "The Many Derelicts of the War'? Great War Veterans and Repatriation in Dunedin and Ashburton, 1918-1928', PhD, Otago University, 2008; Graham Hucker, 'The Rural Home Front: A New Zealand Region and the Great War', PhD, Massey, 2006; Elizabeth Walker, "The Living Death': the repatriation experience of New Zealand's wounded Great War servicemen', MA thesis, Victoria University, 2011.

${ }^{6}$ Proctor, On My Honour, p.3, Cynthia Commachio, The Infinite Bonds of Family: Domesticity in Canada, 1850-1940, Toronto, 1999, p.72.

7 Judith Allen, Sex and Secrets - Crimes Involving Australian Women Since 1880, Melbourne, 1990, p.131; Commachio, The Infinite Bonds of Family, p.70; Stephen Garton, The Cost of War - Australians Return, Melbourne, 1996, pp.179-181, 186-7, 196-201.

${ }^{8}$ Barbara Brookes, 'Shame and its Histories in the Twentieth Century', Journal of New Zealand Studies, No.9, 2010, p.42.
} 
come true. Other scholars have illuminated the shattered lives of men who were wounded, 'shell shocked' and permanently disabled by war. For the majority of men who were discharged as fit however, their successful reintegration into civilian life relied on key factors. This thesis argues that employment, family support, sobriety and good health were important factors in soldiers' return to civilian life. Many men had these dreams affected by the absence of money, family support, or by addiction and illness. This is in comparison to men who had successful experiences repatriating, who often were able to overcome various struggles on return with the help of familial support, financial assistance, supportive marriages, and little interest in alcohol. These men also had relatively light injuries or illnesses that they were able to recover from or work around in their day to day lives. For those who were less successful lack of employment was often the cause of this. Employment gave men something to focus on and ensured a steady income, which were both important factors in successful repatriation. Employment also gave veterans the financial freedom to marry, buy houses, or invest in other projects that they had been planning. The unemployed returnee often found that he was unable to move forward with life, having to delay marriage and other dreams until secure employment came along. For the married man, the stress of maintaining a breadwinner role when employment was scarce was considerable, particularly when temporary employment was all that was on offer. Soldier settlement proved another avenue for employment for men, but some men found that they were unable to make a living off their land, due to the economic downturn, inexperience, unsuitable land, and financial over-commitment. For these men, dreams of being self-sufficient, living a rural, peaceful lifestyle, and raising a family on the land were all shattered. 
Another element of successful repatriation was the ability to limit one's drinking. Unfortunately for some returnees, alcohol had become a crutch, and it was these men who ended up at far greater risk of becoming alcoholics. For those that did, their lives became limited by their addiction, with families suffering financially, emotionally and physically, and with negative effects on employment, as well as resulting in some criminal behaviour. The soldier drinking culture that emerged in the 1920s was in part borne out of the RSA, who provided alcohol at their functions and became a meeting place for returned soldiers. I also argue that those who suffered from Tuberculosis, which was contagious and often fatal, suffered severely in various ways on return. That treatment involved separation, the effects on intimacy with lovers and family, and the ostracism men faced in employment and in public all had negative effects on their post-war life. Furthermore, their families became carers, having to undertake work to nurse their veteran and ensure the rest of the family was safe from TB. For TB men, their safe return from war was betrayed by the contraction of this disease, which often did not present symptoms for quite some time. This disease delayed successful repatriation, and in some cases, killed returnees.

\section{Sources}

I have used extensively the collections of Archives New Zealand in my research. Participation in the Great War meant that Government-produced records of and about men exist in profusion.These records are valuable in that they show the government repatriation initiatives that were being considered before and after the end of the war; they also show problems that arose and the various suggestions for solving these. Inwards correspondence can give some idea of public feelings over certain issues, but in the files that I consulted, inwards correspondence was largely from official bodies - 
for example lawyers, the police or, in the cases of employment, with various employment bodies such as the railways. The medical files contained correspondence from hospitals, sanatoria and health boards. Individual correspondence makes up a large part of the soldier settlement files, simply due to the department's need to be in contact with the settlers themselves to track their progress. These were the only files to consistently portray the stories of individual returned men, and this was only through their reports of struggles or success on their farms, requests for assistance, and the reports of inspectors. Overall, with the exception of the soldier settlement files, these files give an official point of view. This limits the usefulness of the files as an insight into the lives of returned men. However they give a strong insight into the mindset of government departments post-war and the inner workings of various repatriation schemes and plans.

Veterans voices are literally recorded in the World War I Oral History Archive held by the Alexander Turnbull Library. These interviews, conducted in 1988 and 1989 by Nicholas Boyack and Jane Tolerton, recorded 84 elderly veterans on their war experiences, and on their lives post-war. I selected 15 interviews where men spoke about their post-war experiences: their immediate return home, employment, settlement, tuberculosis, and alcohol. These interviews gave an excellent insight into returned men's lives, and the varying experiences these men had. In using these, one must take into consideration that the men interviewed were aged in their mid 80 's or later; therefore those who suffered terribly from illness or wounds are generally not represented, having died younger. Some of the interviewees sustained injuries in the war that were still affecting them, and there was one interview with a recovered TB sufferer. It can also be suggested that the men interviewed were generally more 
successful in reintegrating. Their survival to an advanced age indicates they had potentially suffered less hardship and less physical and emotional stress than their unsuccessful counterparts; they may have been wealthier in general throughout their life and able to sustain healthier lifestyles through good diet and medical care than those whose lives had been marked by financial difficulty. It is also assumed that for these men to make it to an advanced age, they were highly unlikely to be heavy drinkers. ${ }^{9}$ Oral history also must be used knowing the biases that exist in the human memory and expression of such memories. Alistair Thomson argues that all are inclined to construct their life stories in a composed narrative, and that doing so helps us find meaning and gloss over the more painful aspects of our past. ${ }^{10}$ He also points out that memories change over time as our personal identity shifts in relation to other people and our own lives. ${ }^{11}$ Therefore, the memories that returnees shared in these interviews are skewed by their own personal circumstances and feelings, and may be less accurate due to the long span of time passed. Furthermore, successful repatriation may have required these men to repress or downplay their more painful memories. Yet despite these biases, and indeed because of them, the collection gives a valuable insight into the lives of successful returned men, and the stories of some of these soldiers prove to be a useful counterpoint to those of men who struggled to resume civilian life.

Letters of soldiers away from home are also used in this thesis. I read the letters of 10 soldiers, some of whom were writing to wives, one to his fiancée, the rest to families. I also utilised the letters of Mabel Anstice, who wrote to her husband Bert

\footnotetext{
${ }^{9}$ Trevor Lummis, Listening to History, New Jersey, 1987, p.33. Lummis notes an oral history project with East Anglian fishermen, most of whom drank moderately. One interviewee suggested that most of the heavy drinkers among the fishermen had died younger, therefore were not there to be interviewed.

${ }^{10}$ Alistair Thomson, Anzac Memories - Living with the Legend, Melbourne, 1994, pp.8-10.

${ }^{11}$ Thomson, Anzac Memories, p.9.
} 
while he was in camp. ${ }^{12}$ Other letters used are those published in edited collections. ${ }^{13}$ As a historical source, letters are well used and extremely valuable. They provide insight into relationships between various people; they allow the historian to see the concerns, dreams and experiences of those who wrote to one another. Jessica Meyer argues that soldiers' letters served as 'spaces in which men could continue to enact their domestic roles' while at the front. ${ }^{14}$ Letters often provide a comprehensive (although usually one sided) record of a soldier's life and experiences. They bridged the gap between loved ones and show how the writers 'drew emotional sustenance from one another'. ${ }^{15}$ However, letters cannot give a complete insight into a soldier's life. Letters only provide what a soldier chose to share, and this varies with the audience that the letter was intended for. The idea that letters were not only written for intimate contact, but also sometimes to an audience that would include several family members and family friends can have some implications for the readings of these letters. Martyn Lyons points out that French soldiers often wrote letters under the assumption that they would be passed around a family, or an even wider readership. ${ }^{16}$ This was also the case in New Zealand. The other limitations in New Zealand repositories is that, almost exclusively, only one side of a correspondence relationship survives, or in some cases - such as letters written between boyfriend and girlfriend or fiancés - do not survive the end of a relationship. For example, soldier

\footnotetext{
${ }^{12}$ Anstice Family, Letters from May Anstice to her husband, Bert, 1918, MS-Papers-5535-04, Alexander Turnbull Library, Wellington; \& Anstice Family, Letters from May Anstice to her husband, Bert, 1918, MS-Papers-5535-05, Alexander Turnbull Library (hereafter ATL), Wellington.

${ }^{13}$ Peter Howden, Letters, in Jock Phillips, Nicholas Boyack and E.P. Malone (eds.), The Great Adventure, Wellington, 1988, pp.157-194; Wilfred Collinson Smith, Letters, in Jock Phillips, Nicholas Boyack and E.P. Malone (eds.), The Great Adventure, Wellington, 1988, pp.195-228; Len Wilton, Letters to Ilma McLachlan, in Beth Sutherland (ed.), My Dear Chick - A New Zealand Love Story 1911-1948, Masterton, 2008, pp.45-230.

${ }^{14}$ Jessica Meyer, Men of War - Masculinity and the First World War in Britain, New York, 2009, p.15.

${ }^{15}$ Martha Hanna, 'A Republic of Letters: The Epistolary Tradition in France during World War I', American Historical Review, Vol. 108, No. 5, 2003, p.1342.

${ }^{16}$ Martyn Lyons, 'French Soldiers and their Correspondence: Towards a History of Writing Practices in the First World War', French History, Vol. 17, Issue 1, 2003, p.81.
} 
Bert Stokes had a girlfriend to whom he wrote for the entirety of the war, and thought he would marry after the war; however, the relationship ended when he returned to New Zealand. ${ }^{17}$ His large collection of letters he wrote home, now housed in the Alexander Turnbull Library, excludes the letters written to his wartime girlfriend. ${ }^{18}$ This creates an imbalance of surviving letters towards those written to partners who later became spouses - successful relationships - rather than those who split up later on. This makes it difficult to fully ascertain some of the difficulties that occurred in wartime relationships, particularly those that eventually ended those relationships. What soldiers' letters do provide is evidence of idealisation of family life in New Zealand.

Newspapers were also used extensively in my research. The papers I used most frequently were the weekly tabloid NZ Truth and the metropolitan daily Evening Post. Regional papers were also used. Newspapers are a valuable source in that they contain some insight into public interests - the stories that appeared were those that the media thought would sell newspapers, and therefore appealed to public interest and curiosity. They also portray personal stories and accounts of individuals and therefore give the personal angle to this research that sources such as official archives are less likely to give. However, newspapers have their own bias and must be used with this in mind. NZ Truth, for example, was a newspaper given to sensationalism, exposing scandal and political corruption. It has been described as making 'sex and crime its speciality' and seeing itself as 'self-appointed...moral arbiter'. ${ }^{19}$ The 1920 s saw it

\footnotetext{
${ }^{17}$ Nicholas Boyack and Jane Tolerton, In the Shadow of War, Auckland, 1990, p.243.

${ }^{18}$ Bertram Oliver Stokes, letters to his parents, in Stokes, Bertram Oliver, Papers relating to service in World War One, 1896-1994, MS-Papers-4683, ATL.

${ }^{19}$ Redmer Yska, Truth: The Rise and Fall of the People's Paper, Nelson, 2010, p.64.
} 
become more of a 'family-friendly "national paper"' but still driven by 'sensation' ${ }^{20}$ It is unsurprising that the plight of returned soldiers appeared in its pages. The Evening Post was locally focussed and less politically driven, and provided comprehensive reporting of various soldier issues. The regional papers I used lacked NZ Truth's slant of agitation, with reporting similar to the Evening Post, but again, the consideration that stories published were those that would 'sell' is to be considered when using all newspapers. It must also be considered that the views of the journalist writing the article were not necessarily those of the general public, but that these articles could go some way to sway public opinion, particularly among those who had little independent knowledge of what was being reported on.

The Returned Soldiers' Association Quick March is another wide ranging source that I used extensively. It was a monthly newsletter which ran from 1918 to 1923, succeeded by the RSA Review which was much smaller in size. The Quick March contained news from various branches, and gave returned men an advocate, an outlet and a news source. The Quick March focussed on the plight of pensioned and disabled soldiers, but also noted the struggles of those on the land, alcoholic men, and to some extent tubercular soldiers. It also detailed some of the employment struggles men encountered. It contained opinion pieces by various contributors; these are interesting, but also must be read with some caution as it is unlikely that they always reflected the opinions of the majority of returned men. Some articles were also aimed at women who undoubtedly read the Quick March if they had a soldier brother, husband or fiancé. These articles were often aimed at reaffirming the duties of women, particularly in the domestic, private sphere. Quick March informed returned

\footnotetext{
${ }^{20}$ Yska, Truth, p.65.
} 
soldiers of the work that the RSA was doing on their behalf, particularly in terms of its communications and negotiations with the Government. Due to Quick March's focus on soldiers who needed advocacy and help, particularly disabled soldiers, it is a valuable source for finding the stories of men who were struggling to reintegrate, and the actions that the RSA undertook, particularly their lobbying of the government and the outcomes of this.

\section{Historiography}

This thesis engages with and contributes to the general historiography of the 1920s. Historiography of the 1920s in New Zealand and that of returned soldiers' experience have run parallel to each other rather than being well integrated. While researching soldier employment it became apparent that women and their roles in the workplace were one site of intersection. Brookes, Cooper and Law's Sites of Gender provides an important discussion of the division of labour between men and women, including the ideas of the breadwinner wage and the social implications of women in work before and during the $1920 \mathrm{~s} .{ }^{21}$ Economic changes of the $1920 \mathrm{~s}$ are also covered in general histories of New Zealand, such as Tom Brooking's chapter in the Oxford History of New Zealand, which gives important background to how the New Zealand went into a slump post-war, and explains why the price for farming commodities dropped suddenly. ${ }^{22}$ Class and occupation in the late nineteenth and early twentieth century have been the focus of a series of studies originating in the Caversham Project at Otago University. ${ }^{23}$ The impact of the economic slump of the 1920 s on returned

\footnotetext{
${ }^{21}$ Barbara Brookes, Annabel Cooper \& Robin Law, Sites of Gender: Women, Men and Modernity, 18901939, Auckland, 2003.

22 Tom Brooking, 'Economic Transformation' in Geoffery Rice (ed.), The Oxford History of New Zealand, $2^{\text {nd }}$ ed.,Auckland, 1992.

${ }^{23}$ Key texts which illuminate the economic and social issues of the time that came out of the Caversham project are Erik Olssen's Working Gender, Gendering Work', in Brookes, Cooper, \& Law (eds.), Sites of
} 
soldiers, however, has been mainly dealt with by historians of soldier settlement. ${ }^{24}$ Less attention has been paid to the importance of increases in women's workforce participation by historians of veterans. Nor has the uncertainty created by the economic downturn and the return of large numbers of men been extended to its effects on urban returned men. This thesis incorporates existing economic and occupational research into the experience of returned men and argues that uncertainty, unemployment and financial pressure plagued men across the occupational spectrum. Furthermore it focuses on the progress of a particular group of men in society during the 1920 s, and provides an insight into the issues of illness and addiction that were arising in society and receiving greater attention due to returned soldiers.

After the publication of The Great Adventure in 1988 many histories of the Great War used letters to illustrate wartime experiences. ${ }^{25}$ They do not, however, use these letters to ascertain what men were hoping for after the war. This literature reinforces the idea that the war ended in 1918 for men, rather than engaging with the

Gender, pp.50-90 and Erik Olssen and Maureen Hickey's Class and Occupation: The New Zealand Reality, Dunedin, 2005, along with Erik Olssen, Building the New World: work, politics and society in Caversham, 1880s-1920s, Auckland, 1995.

${ }^{24}$ Gwen Parsons, “The Many Derelicts of the War'?'; Ashley Gould, 'Proof of Gratitude? Soldier Land Settlement in New Zealand After World War I', PhD, Massey University, 1992.

${ }^{25}$ Terry Kinloch, Echoes of Gallipoli : in the words of New Zealand's Mounted Riflemen, Auckland, 2005; Christopher Pugsley, Anzac : the New Zealanders at Gallipoli, Auckland, 1995; Chrissie Ward (ed.), Dear Lizzie : a Kiwi soldier writes from the battlefields of World War One, Auckland, 2000; Glyn Harper, Letters from Gallipoli : New Zealand soldiers write home, Auckland, 2011; Glyn Harper, Dark journey, Auckland, 2007; Glyn Harper, Spring offensive : New Zealand and the second Battle of the Somme, Auckland, 2003; Glyn Harper, Letters from the Battlefield: New Zealand Soldiers Write Home, 1914-1918, Auckland, 2002; Glyn Harper, Massacre at Passchendaele: the New Zealand story, Auckland, 2000 all use letters to illustrate the history of the war. Other social histories of World War I that followed the publication of Phillips, Boyack and Malone (eds.), The Great Adventure, are Christopher Pugsley, On the Fringe of Hell New Zealanders and Military Discipline in the First World War, Auckland, 1991; Graham Hucker, 'The Rural Home Front'; Christopher Pugsley, The ANZAC experience: New Zealand, Australia and Empire in the First World War, Auckland, 2004; Boyack and Tolerton, In The Shadow of War; Stevan Eldred-Grigg, The Great Wrong War, Auckland, 2010; Crawford \& McGibbon (eds.), New Zealand's Great War; Nicholas Boyack, Behind the lines : the lives of New Zealand soldiers in the First World War, Wellington, 1989; Matthew Wright, Shattered glory : the New Zealand experience at Gallipoli and the Western Front, Auckland, 2010. 
idea of the war continuing to affect men. Post-war New Zealand is often relegated to a few sentences or the final chapter of books which focus on the 1914-18 war. Nicholas Boyack and Jane Tolerton's chapter 'Aftermath' in In the Shadow of War briefly covers some issues that were important in post-war years. They argue that 'The story of the World War One veteran in New Zealand is one of betrayal' and that the New Zealand government failed to anticipate the needs of returnees, with a most striking example being the closure of the repatriation department in $1922 .{ }^{26}$ This chapter briefly covers various aspects of postwar life, dedicating two or three paragraphs each to issues such as disability pensions, soldier settlement, employment, shell shock, TB and venereal disease. They also touch on the issue of soldier drunkenness and the RSA's role in soldier advocacy. Their work on the World War One Oral History Archive is mentioned in terms of soldiers' reluctance to talk about their war experiences. ${ }^{27}$ Given the scale of information in this repository alone, it is unfortunate that Boyack and Tolerton did not expand their thoughts on the post-war period further. Their chapter provides a brief summary of post-war experiences for returned soldiers, focussing on those who had negative experiences - again, those who spoke most loudly in the historical record. Those with more positive repatriation experiences do not feature in this chapter; instead it lists the ways in which the government dealt badly with various issues. More recently Graham Hucker's study of Taranaki during the war also concluded with a

\footnotetext{
${ }^{26}$ Boyack and Tolerton, In The Shadow of War, pp.245-6. Other studies which mention soldier alcoholism or drunkenness in terms of violence are Elizabeth Nelson's 'Victims of War - The First World War, Returned Soldiers, and Understandings of Domestic Violence in Australia', Journal of Women's History, Vol.19, No.4, 2007, pp.83-106; and Judith Allen's Sex and Secrets.

${ }^{27}$ Boyack and Tolerton, In The Shadow of War, pp.247-8.
} 
chapter called 'Aftermath' in which the tragic effects of the war were emphasised. In this thesis I extend these discussions. ${ }^{28}$

Studies of those soldiers who received pensions are more plentiful than of soldiers who did not. Pensioned soldiers show up in Government records, and their stories are accessible through these records. Yet not all those who suffered from negative effects from the war gained pensions, and it is these men whose stories have not been explored. The impact on families of various hardships and ill effects caused by the war was not only suffered by those who received disability pensions, and this study encompasses these men. Shell shocked soldiers and their plight have been covered in various works. ${ }^{29}$ Disabled soldiers have also received some attention in historical studies, including Marina Larsson's Shattered Anzacs, Elizabeth Walker's recent Masters thesis “The Living Death': the repatriation experience of New Zealand's wounded Great War servicemen', and Peter J. Boston's Honours thesis "'The Bacillus of Work": Masculinity and the Rehabilitation of Disabled Soldiers in Dunedin 1919$1939^{\prime} .^{30}$ These works focus on the repatriation of disabled soldiers. Larsson focuses on

\footnotetext{
${ }^{28}$ Graham Hucker, 'The Rural Home Front'. A recent example of a very negative and brief final chapter in a World War I history is entitled "Aftermath" in Eldred-Grigg, The Great Wrong War, pp.414-467. EldredGrigg does not take into account that some soldiers successfully re-integrated; rather, his entire chapter focuses on the negative effects of war in many aspects, including the negative effects on returned soldiers. There is no acknowledgement that some were able to live good lives after the war.

${ }^{29}$ This includes Garton's The Cost of War; Peter Leese's 'Shell shock : traumatic neurosis and the British soldiers of the First World War' The Journal of Modern History, Vol. 76, No. 4, 2004, pp. 955-956; Fiona Reid's Broken Men: shell shock, treatment and recovery in Britain, 1914-1930, London, 2010; chapters in Jay Winter's Remembering war : the Great War between memory and history in the twentieth century, New Haven, 2006; and Marina Larsson's Shattered Anzacs - Living with the scars of war, Sydney, 2009. These studies are all focussed on other countries - Britain and Australia - however, they provide an interesting insight. Closer to home John Weaver and David Wright's article 'Shell Shock and the Politics of Asylum Committal in New Zealand, 1916-22', Health and History, Vol.7, No.1, 2005, pp. 17-40 concerns the response of the medical authorities to shell shocked soldiers returning from WWI. Further studies into shell shock remain difficult at this stage due to the files on mental health being restricted and of a sensitive nature.

${ }^{30}$ Peter J. Boston, "'The Bacillus of Work": Masculinity and the Rehabilitation of Disabled Soldiers in Dunedin 1919-1939', Hons Thesis, Otago University, 1997; Walker, 'The Living Death'. Other studies include Jessica Meyer's "Not Septimus Now': wives of disabled veterans and cultural memory of the First World War in Britain', Women's History Review, Vol.13, No.1, 2004, pp.117-137; and Kerry Neale's "Without the Faces of Men': the Return of Facially Disfigured Veterans from the Great War', When The
} 
families and the effects that disability could have on the family home, including financial and emotional struggles. Boston's work focuses on the various aspects of repatriation, including pensions and employment, and Walker's thesis argues that disabled returnees struggled with recognition and identity as time went on. This thesis differs from these in that it does not specifically focus on disabled returnees; however, like Larsson, this work examines the impact of post-war circumstances on soldiers and their families, and like all three works, particularly Larsson, discusses tubercular soldiers' plight, including problems with employment.

Stephen Garton's The Cost of War is a comprehensive history of Australian returnees from World War I, World War II, and the Vietnam war. His scope is much broader than this study. However it does provide interesting insights into WWI returnees' experiences. Garton speaks of the dreams that men had for their return, and the displacement that some felt once they reached home. He also writes on soldier settlement, detailing the issues that beset settlers and in particular what caused soldiers to fail, taking an even handed approach and noting that some soldiers did not take to the land well and failed due to this, as well as there being issues with land quality and poor administration for other men. ${ }^{31}$ His discussion of soldier settlement ranges past World War II. His chapter on the return of men to their family focuses on the proliferation of advice literature after World War II, with no focus on World War I. However, it gives some interesting insights into the struggles that men faced on return, particularly those who returned to wives, including problems with sexuality, violence within the marriage, women going out to work, and the ways in

Soldiers Return: November 2007 Conference Proceedings, Brisbane: University of Queensland, School of History, Philosophy, Religion and Classics, 2009, pp.114-120.

${ }^{31}$ Garton, Cost of War, pp.131-135. 
which couples struggled to reconnect after years apart. ${ }^{32}$ These issues arose equally in many men's situations after World War I and are explored in this thesis.

Historians' attention has also been drawn to soldier settlement. Marilyn Lake's book The Limits of Hope, published in 1987, gives a comprehensive insight into the struggles of returned soldiers who owned farms in Victoria under the Soldier Settlement scheme and provided many interesting comparisons and similarities when studying solider settlement in New Zealand. ${ }^{33}$. Lake's study focuses on the reasons behind the scheme, and the suffering that many farmers endured as their lives became marred by poverty. The New Zealand evidence supports Lake's argument that there was a perception that farmers were used to "roughing it' in the trenches' and that this would 'fit them to tackle land settlement and put up with inconvenience'. ${ }^{34}$ She also confronts the living conditions of settlers, which were often much worse than their New Zealand counterparts, and delves into the lives of settlers themselves, telling their stories. Lake focuses on the supervision of soldier settlers, devoting a chapter to this, and more generally on the monetary costs of the settlement project. Lake condemns the settlement project as a failure, focussing on the stories of those who failed and states that this was the last attempt by Australia to create a class of yeomen. Indeed, while Lake argues for the need to get soldiers off the streets where they were causing trouble as a reason that the settlement programme was brought in, she largely focuses on the Yeoman ideal as the reason behind the scheme. ${ }^{35}$ She also spends some time examining the role of wives and children as labourers on settlement farms. Her study

\footnotetext{
${ }^{32}$ Garton, Cost of War, pp.178-201.

${ }^{33}$ Murray Johnson "'Promises and Pineapples": Post-First World War Soldier Settlement at Beerburrum, Queensland, 1916-1929', Australian Journal of Politics and History, Vol.51, No.4, 2005, pp.496-512; and Allan Rost, 'World War I soldier settlement: Government attempts and some private contributions', Journal of the Royal Australian Historical Society, Vol. 94, Is.1, 2009, pp.38-56.

${ }^{34}$ Marilyn Lake, The Limits of Hope: Soldier Settlement in Victoria 1915-1938, Melbourne, 1987, p.40.

${ }^{35}$ Lake, Limits of Hope, pp.11,29
} 
shows the similar problems that Australia's settlers had when farming, yet also shows that in many ways Australian soldiers faced hardships that New Zealand's settlers were able to avoid. It appears that the New Zealand Government was more lenient towards its settlers than Australia's Government.

Australian historian Marina Larsson covers many aspects of disabled returnees lives in her 2009 book Shattered Anzacs. She focuses on the disabled and ill returnees of war, and the effects that their illnesses and disablement had on family life. This particular angle, and her chapter on tuberculosis, proved to be immensely useful, as little research has been done on the effects of tuberculosis on returned soldiers and their families. Larsson's chapter provides this, and her argument that tuberculosis could "cast one of the "longest of all the shadows of war" over family life and the health of their loved ones' is particularly strong and poignant. ${ }^{36}$ Her writings on the effects of tuberculosis on returned soldiers, the stigmas they faced in society, their struggles to gain employment, and the loss of intimacy that could occur in families all correlate with the New Zealand TB man's experience. ${ }^{37}$ Larsson also argues that for many men, 'the trauma of war did not end in 1918 - instead the aftermath began' ${ }^{38}$

\footnotetext{
${ }^{36}$ Larsson, Shattered Anzacs, p.179.

${ }^{37}$ Writings on TB in New Zealand are sparse, however Susan Haugh, 'The Hill of Health: Aspects of Community at the Waipiata Tuberculosis Sanatorium, 1923-1961', Health and History, Vol. 11, No.2, 2009, pp. 1-20, gives some insight into the sanatorium experience, as does T.O. Enticott, Up the hill : Cashmere Sanatorium and Coronation Hospital, 1910 to 1991 Christchurch, 1993, which gives details of sanatorium life for military patients. Peter J. Boston's Honours thesis "'The Bacillus of Work": Masculinity and the Rehabilitation of Disabled Soldiers in Dunedin 1919-1939', Otago University, 1997, gives details on ex-servicemen's treatment in sanatoria and post-sanatorium experience. For a British perspective, Linda Bryder's Below the Magic Mountain, New York, 1998, gives a perspective on treatment for TB sufferers. Ann Herring and Alan C. Swedlund's (eds.) Plagues and epidemics : infected spaces past and present, New York, 2010, pp.119-152 contains two essays of interest. The first, by Judith Lyttleton, Julie Park and Linda Bryder, 'The End of a Plague? Tuberculosis in New Zealand', pp.119-136, discusses TB as a 'plague' as opposed to other illnesses, and the end of the TB plague, and mentions returned servicemen suffering from TB, but has a different focus than this thesis. Andrew Noymer's chapter 'Epidemics and Time: Influenza and Tuberculosis during and after the 1918-1919 Pandemic', pp.137-152, discusses the interrelated roles of the two diseases on one another. Both of these chapters focus on the disease itself rather than the stories of its sufferers.

${ }^{38}$ Larsson, Shattered Anzacs, p.17.
} 
This argument is central to this thesis also; while this work discusses the broader effects of war, rather than disablement, it still shows that for returnees struggling to repatriate successfully, and facing many obstacles, the concept of 'the aftermath' and the long-reaching effects of war is plainly applicable.

Larsson's scholarship provides the most comprehensive study thus far on Australian returnees, however, no such study exists concerning New Zealand soldiers. Various studies of aspects of repatriation do exist, however. Ashley Gould's 1992 PhD thesis, 'Proof of Gratitude? Soldier Land Settlement in New Zealand After World War I' is a comprehensive study of the government scheme. His focus is on the reasons behind the failure of the settlement scheme, but he also challenges the idea that the scheme was a massive failure, or that returnees were passive victims of the scheme, noting the role of personal agency in choosing land plots that later turned out to be unsuitable, and that some soldiers may have found they disliked farming, and walked off the land due to this. ${ }^{39}$ Gould's thesis is useful in terms of examining government justification for and actions in terms of soldier settlement, and some media representations of soldier settlement. However, it does not delve into the personal experiences of soldier settlers, and the reasons behind their own, personal failures or success. Gould's thesis fills a gap in historiography by discussing in depth the settlement programme, and provides useful background knowledge when examining the scheme, but his thesis' focus differs to my own research, leaving personal experiences undescribed. My thesis is concerned less with success or failure but looks at soldier settlement as an example of the government's attempts to find employment for returned men. Other studies on soldier settlement are shorter and less

\footnotetext{
${ }^{39}$ Ashley Gould, 'Proof of Gratitude? Soldier Land Settlement in New Zealand After World War I', PhD, Massey University, 1992, pp.297,299
} 
comprehensive, but also useful; Gwen Parsons provides some personal soldier experiences and a more localised study, while Michael Roche focuses on the political aspects of soldier settlement. ${ }^{40}$

Alcoholic returnees are largely absent in the historiography, possibly due to the sensitive nature of their ailment and the potential embarrassment that such a condition could cause. Stephen Clarke's chapter 'Return, Repatriation, Remembrance and the Returned Soldiers' Association' written in 2007 briefly addresses the RSA's concern for alcoholic soldiers, the soldier reputation for excessive drinking, and the role of RSA clubs in this. ${ }^{41}$ Prohibition is another lens through which to look at the soldier drinking question, and Paul Christoffel's article 'Prohibition and the Myth of 1919' explores the idea that the prohibition movement lost momentum after its defeat at the polls in 1919, and instead argues that it continued to be a strong force throughout the 1920s. His statistics on the poll in April 1919 show that returned soldiers voted strongly against prohibition. ${ }^{42}$ My thesis draws upon the above sources along with numerous primary sources to argue that returned soldiers did indeed have a reputation for drinking, that the RSA clubs often fostered a drinking culture among returnees, and that some men's drinking became problematic to the point of their coming to the attention of the media or authorities due to actions under the influence.

\footnotetext{
${ }^{40}$ Parsons, “The Many Derelicts of the War'?', contains a chapter on Soldier Settlement in Ashburton county, detailing the problems and issues specific to this settlement. Michael Roche's chapter 'Empire, Duty and Land' in Lindsay Proudfood and Michael Roche (eds.) (Dis)Placing Empire - Renegotiating British Colonial Geographies, Hampshire, 2005, pp.135-153, discusses both the legislation surrounding the soldier settlement programme and makes some arguments about why the programme was seen as a good idea.

${ }^{41}$ Stephen Clarke, 'Return, Repatriation, Remembrance and the Returned Soldiers' Association 1916-22', in Crawford \& McGibbon (eds.), New Zealand's Great War, p.170.

${ }^{42}$ Paul Christoffel, 'Prohibition and the Myth of 1919', New Zealand Journal of History, Vol.42, Is.2, 2008, p.154; also, Margaret Tennant's Masters thesis 'Matrons With A Mission: Women's Organisations in New Zealand 1893-1915', MA thesis, Massey University, 1976, provides some useful background into the work of the Women's Christian Temperance Union.
} 
This thesis also argues that returned soldiers were a target for prohibitionists during and after the war due to their reputation for heavy drinking.

The historiography of post-World War I New Zealand is still developing. However, there has been significant work done by historians to illuminate various aspects of returnees' lives. Australian studies have also contributed to this because of the similarities to the New Zealand historiography, and Australian studies on soldier settlement and disability and illness are much more developed. However, the experiences of tubercular and alcoholic returnees in New Zealand are under researched, as are the experiences of those seeking employment on return. Soldier settlement has a larger body of research dedicated to it, but most of this focuses on the success or failure of the scheme. I am focusing on filling these gaps in the historical record with my research. This includes those unemployed post-war, the intemperate, and the unwell who were not necessarily receiving pensions.

My first chapter focuses on the dreams soldiers had for their return, the emotional bonds they held on to while they were away, and what the reality of life was once they returned. Using soldiers' letters I have examined what it was that they were hoping for on return, in particular in their personal lives and future careers. I have also explored the things from home men missed - such as home comforts - and the way that they idealised home in general. The second half of this chapter uses the World War One Oral History Archive to illustrate men's experiences on return, in particular those who had successful experiences of repatriation. This is a counterpoint to the stories of men who had less successful experiences, which make up the remainder of the thesis. Throughout this chapter I argue that men were thinking of what they wanted from life post-war while they were away, and formed expectations on what 
home would be like. I also argue that when they returned, some of these expectations were not met, and that men found themselves in situations very different to what they imagined. Furthermore, I identify the key elements to successful repatriation - as expressed in the reminiscences of returnees - employment being the most important.

Chapter 2 explores the important issue of employment on return including the soldier settlement programme. In particular it looks at the problems that stopped men being able to find employment. I argue that the economic conditions, competition for available jobs, and men having to leave behind training and educational opportunities to go to war all contributed to this. Furthermore, the presence of women in jobs that men had left behind, women who were paid at lower wages, also contributed somewhat to this. I argue that this led to desperation among returnees, and that men had to take up temporary employment which undermined their security and left them insecure in their lives. Soldier settlement was touted as an alternative to this, but I argue that it also held little in the way of security for many men. The problems that plagued soldier settlement - bad land quality, inexperienced farmers, and severe financial issues also undermined returnees' security as they tried to establish themselves and their families on the land.

Chapter 3 looks at the effects that alcohol had on returned soldiers, and on their reputation in society. I argue that alcoholism affected many returnees, but that these men's illness was hidden in the historical record due to its sensitive nature, the subjective definitions of alcoholism, and the fact that soldiers were 'known' for drinking. I argue that the drinking culture of the front came home and revealed itself through the RSA. The RSA's drinking culture undoubtedly harmed some men and led to heavy drinking in their lives, or a continuation of heavy drinking after the war. Grateful 
civilians and the general frivolity of return also led to men overindulging in booze. Returnees were targets for prohibitionists due to their reputation for drinking, and were made an enemy by preventing prohibition in the April 1919 poll with their votes. I argue that the drinking problems that did become visible in the record were often due to the committing of a crime or neglectful or antisocial behaviour. The media portrayed the stories of such men and connected their returned soldier status in the articles. These stories illuminate the problems that alcohol could cause: family breakups, physical violence, and problems with employment and finances. This sad legacy of the war undermined stability and happiness for these men and their families.

Chapter 4 focuses on veterans who returned from war with tuberculosis. This chapter argues that TB was a debilitating disease that could have detrimental effects on family life, intimacy, job prospects, and the ability to function in society, and held these men back from reintegrating fully. Tuberculosis sufferers lived with the stigma of their contagious disease. I argue that sanatorium stays, sometimes in remote locations, removed sufferers from their family support and left them worrying for their families at home. The treatment that men had to undertake and the lifestyle they had to adopt was isolating, and created extra work for those who had to take care of them. Their disease, which was highly contagious, restricted intimacy with lovers and children, although some chose to ignore these restrictions at their own risk. This disease also, in some cases, spread to family members creating extra stress, pain and trauma for those trying to cope with already having to take care of an ill loved one. Stress also came in the form of pension difficulties, with some men struggling to prove that their TB was war related. Financial stress could arise from the costs of treatment and some men's inability to work or find employment. As late as 1929 TB returnees 
were struggling to find employment due to public fears of the disease. Tuberculosis prevented veterans from being able to resume their lives fully.

What ties together all of these experiences are the effects that they had on the lives of returnees. All of these factors could cause financial stress, familial stress, and frustration for men trying to reintegrate. They undermined the stability of those who were facing them, creating uncertain futures and in some cases restricting or destroying dreams. These dreams, of a secure, happy future, of families and long lasting love, of an enjoyable productive career, were what all returnees had in common. 


\section{Chapter One: Dreaming of Home, Returning Home, and Making a Go of it}

I'll be a weird bird when I get home, I expect, unable to sleep more than a few hours at a stretch and wanting to be up at daylight, want everything run to routine, able to shave in two minutes, able to eat anything, and, I am afraid, smoking like a chimney. ${ }^{1}$

- Cuthbert William Free

The experiences of thousands of men who went to World War I are well documented in many forms, including letters, diaries, memoirs, and interviews, and they tell historians what these men were anticipating, dreaming, and planning for their postwar lives. What did their dreams centre on? What plans did they make? With whom did they make these plans? These are all important questions when thinking about the mindset of returned men as they formed hopes and dreams for their reunion with family and friends, and for the future. Men's post-war experiences need to be contextualised by what they were expecting post-war; it is then possible to see how these dreams differed from their post-war lives. The struggles that these men faced in trying to build lives for themselves were directly related to the dreams that they had for their lives. Expectations are also important in establishing how soldiers perceived home and how this may have affected their experiences once they returned there. Both the changes that took place while they were gone and the ways that the war had changed them had an influence on their post-war experiences of home. These changes affected many areas of their lives including their personal relationships which, if impacted negatively, could leave men without vital support structures that were needed during what could be a difficult or unsettled time. Yet one must also consider

\footnotetext{
${ }^{1}$ Cuthbert William Free, Letter to family, 21 February 1916, Free Family, Letters, 1914-1919, MS-Papers4387, ATL.
} 
that not all men who returned had overly bad experiences. It is important to recognise that many men were able to return from war and resume their lives with relative ease, and other men faced some challenges but were able to overcome them due to a number of factors in their favour or due to better choices. The success of these men also was often due to luck; other times it was due to occupation, better health, or wealth; or the ability to access monetary support. It would be wrong to say that successful men worked harder or were inherently 'better' than those who were not successful; this chapter aims to explore this by showing the experiences of these men and how various factors played into their eventual success. In this chapter I will show some of the fantasies and dreams of soldiers at the front as written in letters from the front. I will then show some of the difficulties these fantasies could create on return. Finally, using the oral history interviews of World War I veterans, I will tell the stories of some men who succeeded post war, describing some of the difficulties they faced and the ways in which they overcame these, showing that many men had positive experiences post-war.

Homesickness in a war situation had the additional factor of the horrors that men had to witness in battle. Home had a much greater appeal to these men simply because it was a place untouched by such horrors, and those who were waiting at home had not witnessed the sights that these men had. Soldiers at war lived a strange and changeable life, with intense periods of fighting at the front interspersed with sometimes long periods of rest and time spent in camps or on leave. This life of terror and adrenaline broken with boredom and a slower pace made for different kinds of longing for home. It can be argued that soldiers viewed home with nostalgia, and that some men not only longed for home itself, but the innocence that it held before the 
war - innocence that was lost to them forever, even if they returned. Soldiers wrote home while at the front lines and on leave, and often while doing so would fantasise about what was happening there or about the life that they would live after the war. One issue to consider when looking at these fantasies of home is how much must have become idealised during the war. After years away, it could have become easy for soldiers to imagine home, and the people there, somewhat differently and more idealistically to how they really were, or to imagine them as they were when they left New Zealand - which over the course of years may have changed.

Letter writing was one very important way to maintain links with home, and a sign that soldiers were actively involved with and using their support networks when they left New Zealand. Soldiers wrote thousands upon thousands of letters home, and received just as many. Those that were received at the front are rare in the historical record simply because soldiers could not carry large volumes of letters with them. Sometimes these letters survived the war due to soldiers sending the letters they received back home, but this is the exception, rather than the rule. Therefore it is difficult to investigate what those at home were expecting and anticipating in terms of their loved ones' return. However, we do know that there were often high hopes for happiness upon return. Loved ones often longed to be reunited, and expressed this often. Letters provided a place to bridge this gap between home and the battlefield. The details contained within were often comprehensive descriptions of battles, along with mundane details of life in the trenches, on leave, and in camps. Soldiers wrote of their fear and grief, using their letters home as a place to share feelings they perhaps could not share with anyone on the front. Letters were not necessarily a place that was safe from the realities of war, showing that soldiers put considerations about 
frightening loved ones aside due to their need to share these experiences. ${ }^{2}$ While those at home did not experience the war first hand, they certainly were not shielded from hearing of the experiences that men had at the front, often in horrifying detail. This suggests that those on the home front did have some idea of what men had experienced when they returned, and also shows that this correspondence was not only a way of staying in contact, but a way of trying to obtain emotional support or a form of release for the soldiers. Men were not only relying on other men at the front for support, and this is important when thinking about the dynamics of post-war relations. Men who returned often sought out the same support network that they did while at war: their families and loved ones. These people were often well aware of what men had seen at the front.

Many relationships were sustained over years by nothing but letters and photos passing backwards and forth. Martha Hanna describes this, stating

Simultaneously dialogical and intimate, they [letters] alone show how men and women shared their experiences of war, drew emotional sustenance from one another, and in the process transcended the gender divide imposed by war. ${ }^{3}$

Mothers, fiancées and sisters communicated with soldiers at the front over the long periods of their separation. Yet while letter writing did maintain their relationships, it is difficult to say how effectively they did so. The delays between letters being written and received, and the difficulty of lack of tone and expression in letters, along with the limitations of the writer, some of whom were infrequent writers or unable to express themselves well, restricted communication in some ways. Arthur Pounteney

\footnotetext{
${ }^{2}$ See Coralie Clarkson, 'How Soldiers' Reactions to Death and Bereavement and the Horrors of War Were Portrayed Through Letters and Diaries', Honours Thesis, Victoria University, 2009.

${ }^{3}$ Martha Hanna, 'A Republic of Letters: The Epistolary Tradition in France during World War I', American Historical Review, Vol. 108, No. 5, 2003, p.1342.
} 
complained to his wife 'I have been left you nearly 9 months, [sic] and have had only two letters from you in all that time. Surely you might find time to write a postcard merely to say that you are alive'. ${ }^{4}$ His wife's prolonged stretches without writing led to him complaining 'This silence of yours drives me nearly crazy at times, Em, and you try my patience severely'. His lack of connection and news from home upset him very much, as evidenced by his strong words. He also noted that he did not write of his feelings towards her, stating ' I am not at all inclined to let the censor ready my private messages. They are for your ears only'. ${ }^{6}$ This limited the more intimate sentiments that he may have wished to send her; these may have reached her in more coded ways. Letters were certainly no substitute for human presence, and this is obvious when reading the letters. Lindsay Inglis wrote of his longing for physical presence in one letter to his fiancée May Todd, noting that 'One very badly wants something he can see and touch from "that other life." I do anyway'. ${ }^{7}$ One way of attempting to bridge this gap was to send photos or other objects, and this was something soldiers often longed for. Inglis made this plain, writing 'Chick, send me some more snaps of yourself - please..$^{8}$ Harry Glass also asked for photos of his family, writing to his wife

By the way what about getting your photo taken with the kiddies and sending it to me, you know how much I would think of it and how much it would be to have it by me. Do try and let me have them. It seems about 20 years since I had you with me. Honest. ${ }^{9}$

\footnotetext{
${ }^{4}$ Arthur Pounteney, Letter to Emma, 7 June 1915, in Pounteney, Arthur, Letters, 1915-1918, MS-Papers6712, ATL.

${ }^{5}$ Pounteney, Letter to Emma, 28 November 1915.

${ }^{6}$ Pounteney, Letter to Emma, 14 April 1917.

${ }^{7}$ Lindsay Inglis, Letter to May Todd, 17 June 1916, in Inglis, Lindsay Merritt (Major General), Papers, 1894-1966, MS-Papers-0421, ATL.

${ }^{8}$ Inglis, Letter to May Todd, 18 May 1916.

${ }^{9}$ Henry (Harry) Glass, Letter to Judy, 10 February 1918, in Glass, Henry, Letters, 1917-1918, MS-Papers8983, ATL.
} 
Glass' request for a photo is tied up in his longing to see his family again. It seems that he feels that by having a photo of them nearby, their presence would also be with him, helping to ease the frustration he felt at not having them with him, and in particular, his missing his wife. Another example of this is Bert Stokes' use of pictures to cheer himself up, writing

I have quite a collection of photos and snaps now and some days when everything seems to go wrong I just have a peep at you all and that seems to do the trick. Yes, I do think of home, of loved ones and sometimes I do long to be with you all again. ${ }^{10}$

For Bert, looking at the photos reminded him of the people that he had at home and perhaps helped him to remember who he was fighting the war for. However, it may have lowered his overall morale, by making him long for home and all those who were there, even if it made him feel better at the time. Many soldiers may have tried to shut this out; homesickness had little use when it came to trying to cope with the war experience. Bert's photo-gazing potentially had both positive and negative effects on his mood, but helped him to remember those at home.

Receiving pictures also kept soldiers up to date with their loved ones' lives, able to see any physical changes in them and of landscapes. Len Wilton wrote to his girlfriend Ilma 'It will be glorious to get back \& able to have a look at all the old faces again. I have been half expecting to get a few snaps that you have taken but so far have been disappointed'. ${ }^{11}$ He also wished he could share some of his experiences with her through photographs, adding 'I would like to have got some photos of what has

\footnotetext{
${ }^{10}$ Bertram Oliver Stokes, letter to his parents, 27 Feb 1918, in Stokes, Bertram Oliver, Papers relating to service in World War One, 1896-1994, MS-Papers-4683, ATL.

${ }^{11}$ Len Wilton, Letter to Ilma McLachlan, 22 October 1917, in Beth Sutherland (ed.), My Dear Chick - A New Zealand Love Story 1911-1948, Masterton, 2008, p.180.
} 
been going on over here. ${ }^{12}$ The difficulty of expressing everything through letters, particularly when trying to describe landscapes and events, is shown in this comment. Wilton commented on his struggles to write at times, and notes this at the beginning of many of his letters, using the phrase 'Here I am again trying to write you a few lines', along with the statement that 'I am getting sick of the sight of writing paper \& will be glad when this war is finished \& I am able to come home'. ${ }^{13}$ Wilton disliked the effort of writing, particularly when he was exhausted from battle, although he was always pleased to receive letters. ${ }^{14}$ This effort was tied up in the frustration of separation, and his desire to return home. Despite this, he corresponded with his girlfriend and other family members often, seeing the importance of maintaining relationships at home. The very fact that he continued to write to IIma often and at length shows the effort he put in to maintaining this relationship through letters. For Wilton, this paid off with him marrying IIma in $1920 .{ }^{15}$

Physical presence in letters was not only manifested in the photos and tokens sent to one another, but in the very fact that the letters had been written by loved ones. Martha Hanna argues that

the letter itself was a physical artifact that could cultivate intimacy by making the absent correspondent seem almost palpably present. Even the simplest letter bore witness to the physical existence of the writer. ${ }^{16}$

The comfort of knowing that a letter received had been handled, penned and sealed by their loved one could be great to some. The basic principles of intimacy - for example, touch - could be transmitted through the exchange of letters. Letters could

\footnotetext{
${ }^{12}$ Wilton, Letter to Ilma, 22 October 1917, My Dear Chick, p.180.

${ }^{13}$ Wilton, Letter to Ilma, 13 May 1917, My Dear Chick, pp.140-153.

${ }^{14}$ Wilton, Letter to Ilma, 29 July 1917, My Dear Chick, p.156.

${ }^{15}$ Beth Sutherland, 'Family Life', My Dear Chick, p.233.

${ }^{16}$ Hanna, 'A Republic of Letters', p.1348.
} 
become somehow alive in themselves, filled with the language and turns of phrase that the writer used. In this way they helped sustain relationships by giving the writers presence in each others lives in the only way that was possible during a separation at this time. Thus a sense of intimacy was created in a place where no such intimacy was possible. While this was no substitute for human presence, it was certainly enough to sustain family relationships, and some romantic relationships.

This is particularly noticeable among men who wrote to fiancées or girlfriends. Impatience and longing to start a new life together characterised these men's writings about home. Some particularly strong examples of this was Inglis' writings. Inglis wrote to May of his frustration in 1916: 'I only wish I could be with you now. Never mind. We shan't be so very long anyway and when the time does come we'll make up for all these months with a vengeance. ${ }^{17}$ Inglis' comments present an idealistic vision of how their lives will be once they are reunited. He clearly planned to spend as much time with her as he could; something which was certainly possible. He also could have been speaking of his intentions to marry her when he returned. One memorable letter contained a long and detailed description of a day that he would have liked to experience with her.

Tell me dear, what do you want to do to-day? Because you, you see, I'm waiting to start. If I can't actually have the day with you I'm going to have a dream day with you. In France? No, missus o' mine - N.Z. will do quite well, thank you. ${ }^{18}$

Interestingly, this day is lived out in the landscapes of home - Inglis clearly misses the country that he lives in, imagining the landscape:

\footnotetext{
${ }^{17}$ Lindsay Inglis, Letter to May Todd, 20 May 1916.

${ }^{18}$ Inglis, Letter to May Todd, 9 July 1916.
} 
Here there there are hawthorn hedges, little creeks with willow trees, and we pass small farms.... [the path] leads down hill for about a quarter of a mile in among the most fascinating bush and hills till we pull up at a little stretch of grass alongside a cool, clear little river... ${ }^{19}$

There was also underlying sexual tension in his imaginings, showing one of the less talked about issues of separation and another aspect of the fantasies of those who were separated. Inglis used one section of the letter to hint at this:

The temptation of a dip is too much, so we'll have one, missus dear....No towels? Well you can use the combined handkerchiefs of the party if you like....Then we'll pick a nice spot...we'll spend some of the time with the book and some without it. I'm not going to attempt any details, missus, for methinks you will be able to supply them. N'est ce pas, ma amie? ${ }^{20}$

Inglis discreetly hints at the possibility of physical pleasure between them, which is not uncommon in war letters - the frustration of years apart manifested in many ways. This day is constructed in the mind of Inglis and is a fantasy; whether the pair ever managed to recreate such a day once he returned is unknown, but they did marry in 1919 when Inglis returned. This example shows exactly the nature of the conjecture that men made when writing about what they would do when they returned home. Inglis, in another letter, notes that his war experiences are 'quite, quite different from anything that you and I are looking forward to. ${ }^{21}$ Life at war was at an extreme opposite from life in peacetime - the disconnection from home, uncertainty about the future, and, at times, fears for one's life were all factors in this. This comment shows that Inglis was holding his future with May, and the parts of this that they had planned out, as a very different, separate part of his life - and suggests that what they were looking forward to - presumably being reunited and starting a future together - is

\footnotetext{
${ }^{19}$ Inglis, Letter to May Todd, 9 July 1916.

${ }^{20}$ Inglis, Letter to May Todd, 17 June 1916.

${ }^{21}$ Inglis, Letter to May Todd, 17 June 1916.
} 
much better than what the war had to offer. Most men at the front had little concept of how much or how little their lives could be changed when they returned - how different society would be, whether their family situations would be unchanged, and how successfully they could secure jobs. Their future security was based not only on their own actions, but on the climate of society and the economy at the time. These were factors that were out of their control.

Being able to pick up where they left off meant fathers had to stay in touch with their children's progress. Harry Glass' concerns were for his family, in particular his children, who he referred to throughout his war correspondence as the 'dear kiddies'. ${ }^{22}$ It appears that he corresponded with his children individually, as well as writing to his wife most often. What comes through in his letters is his affection for his wife and children, and his particular longing to be with his wife again. He wrote after embarkation 'I wish often that I were nearer to you dear'. ${ }^{23}$ Early the next year he wrote optimistically 'Well some day soon, perhaps earlier than any of us thinks, I may be back to the old place again, and we will have our second honeymoon dearest' ${ }^{24}$ Such thoughts worked both to keep Glass optimistic and to reassure his wife that he was hoping to come home soon. He also alluded to the romance between them, as a way to ease the pain of separation and give them both something to look forward to. This also shows Glass' hopes for reunion - that they would be able to spend some time together alone. Glass also wrote of their wedding anniversary: 'This letter should reach you on the anniversary of our wedding day dearest....And although I am not with you to celebrate the great event, you can imagine easily enough how much I wish it. ${ }^{25}$ His

\footnotetext{
${ }^{22}$ Glass, Letter to Judy, 10 August 1918.

${ }^{23}$ Glass, Letter to Judy, 14 October, 1917.

${ }^{24}$ Glass, Letter to Judy, 3 January, 1918.

${ }^{25}$ Glass, Letter to Judy, 5 June 1918.
} 
anticipation of this date again shows his romantic thoughts about her and his wish to be with her. He expresses his dreams of home thus: 'there always is the passionate longing for you my dearest our home and our dear kiddies. ${ }^{26}$ However, Glass does express some anxiety at the thought of his return in the face of his wife's ability to manage without him, writing "It will seem as if I will be a "spare part" when I get home, however I will get over it, don't you think so. ${ }^{27}$ His anxiety is tempered by his assertion that he will get over it; the tone of this suggests that he sees the overall benefits of being home as trumping any worries over his role there. However, this anxiety, whether slight or large, was likely felt by many men on seeing that life was continuing easily enough without them. Glass' observation is tempered by his obvious longing to be home again, and to see his wife - a longing that he voiced many times in his correspondence.

Soldiers at the front reminisced in their letters home to loved ones. These were often full of nostalgic thoughts of their past, and plans for a happy future. Peter Howden, who did not survive the war, wrote home to his wife Rhoda about the time he spent with her at home, reminiscing particularly over proposing marriage to her, writing 'Several times today it has all come back to me with wonderful clearness and I have almost "lived" that beautiful night over again. ${ }^{28}$ Howden used memories to cope with his separation from Rhoda and to feel close to her. In a later letter he reminisces on their honeymoon, before writing

...l am sure when we are old and frowsy...we will have many a laugh at the recollection of it all. And we will amuse our grandchildren by telling them about

\footnotetext{
${ }^{26}$ Glass, Letter to Judy, 10 August 1918.

${ }^{27}$ Glass, Letter to Judy, 27 June 1918.

${ }^{28}$ Peter Howden, letter to Rhoda, in Jock Phillips, Nicholas Boyack and E.P. Malone (eds.), The Great Adventure, Wellington, 1988, p.166.
} 
the funny old things called Fords which we had to get about in when we were young. $^{29}$

Howden clearly hoped that his life would return to normal after he returned home. His knowledge that Rhoda was pregnant at the time surely fuelled these thoughts, and his thoughts of the long-term future. ${ }^{30} \mathrm{He}$ also referred to 'Sundays at Karori, tennis, skating,...all those simple, innocent days of ease and pleasure' ${ }^{31}$ Howden's thoughts of home relate to the innocence of times past as opposed to the situation that he was now in. To Howden life had lost that innocence. However, from his other imaginings about the future, he clearly hoped that some of this could be regained. This was potentially the hope of many soldiers; an innate sense that life could go back to the way it was pre-war, and this was reflected in Lindsay Inglis' imaginings of home also. Howden also referred to his pre-war days as simple and reflected on their ease and pleasure. Howden's current experiences led him to look back on his pre-war life through a very idealistic frame. Howden's writings demonstrate that memories of happy times could become built up in the minds of those who were coping with the realities of war, causing them to view civilian life as overly simple and easy, while in reality it had its own difficulties. These difficulties were less extreme than those faced at war, but were valid nonetheless. However, such thoughts may have led men to believe that life post-war would return to this golden state of simplicity and happiness - a respite from war was sure to bring happiness. For many men, this was not the case, due to both internal and external factors.

\footnotetext{
${ }^{29}$ Howden, letter to Rhoda, The Great Adventure, 166-67.

${ }^{30}$ Howden, letter to Rhoda, The Great Adventure, p.167.

${ }^{31}$ Howden, letter to Rhoda, The Great Adventure p.171.
} 
The experiences of war could also simply highlight the home comforts that men had grown used to and had likely taken for granted. Wilfred Smith wrote home to his wife

Well dearest I am dead tired and absolutely sick of the Camp here, and would give anything to be home with my dear ones. Ethel dear you will find a great change in me when I come home and I don't think you will ever again hear me complain as I will appreciate my home and wife and children too much to do so. ${ }^{32}$

He reiterated this statement in a later letter, stating

Well dear I would give anything to be home now and I am sure you would find a great change in me and you would never be able to get a growl out of me. Your very worst cooking would be a treat after what I have had since leaving home and as for puddings that I wouldn't touch at one time I would give anything for now. ${ }^{33}$

The food in camps, especially under ration conditions, could make previously unappealing meals seem like luxuries, and the monotony of their diet could have made them desperate for richer, more varied foods. Smith's new appreciation of what he was provided was only brought on by the absence of choice in his diet. Another example of this is the musing of Thomas Lynch, who noted 'Still getting three meals a day....But the meals are not like the meals I used to get from you. I don't think l'll ever refuse food at home again after the breaking in I have had on this ship'. ${ }^{34}$ Again, the change in diet, particularly to less desirable foods, led men to dream of the food and comforts of home, and to adjust their expectations to simpler tastes.

Women's hopes for the future can be read through men's responses to these hopes. The letters detailed above show men's affectionate writings home to their

\footnotetext{
${ }^{32}$ Wilfred Collinson Smith, letter to Ethel, The Great Adventure, p.213.

${ }^{33}$ Smith, letter to Ethel, The Great Adventure, p. 215.

${ }^{34}$ Thomas Lynch, Letter home, 17 September 1917, in Lynch, Thomas, 1917-1918 MS-Papers-10272, Letters home during World War One, ATL.
} 
wives, and their longing to be with them again - and it can be presumed that women responded to this positively, particularly when such sentiments were repeated. Women's writings to men during the war are difficult to find, however, some do exist, such those between Mabel and Bert Anstice. The couple lived in Nelson, and Bert was called up relatively late into the war as he was a married man. He wrote to her from Trentham Military Camp near Wellington. Their correspondence to one another concerned their child, household matters, and the running of the family business, which Bert had been heavily involved in before the war. Bert reflected on memories of his home leave (when men encamped were permitted to travel home) and the domestic aspects of his life when thinking of home. He noted in one letter

I envy the fellows here who are able to get home for week ends for it would be very pleasant...especially when I picture Mabel \& Baby in dining room Selwyn Place just about this time 6.30 near bedtime for little Margy...I would much prefer home to this. ${ }^{35}$

His home leaves acted as a sore reminder of the separation he had to endure from his wife. He wrote to her a week after returning to camp from a home leave, 'I just felt I had to put a note in to tell you how much I do long to be with you once again and how much I miss you....you need not worry over my falling by temptation...I am yours and yours only...I will treasure you more than ever if I do get back to you once again' ${ }^{36}$ This reassurance of fidelity and love not only quelled the worries of separated lovers, but also acted as a trigger for Mabel to reassure him similarly. ${ }^{37}$ He also expressed his wish to help her with parenting, sympathising 'I am sorry that Margy is causing you trouble \& that she is unwell and I am sorry I am not at home to help you through at nights

\footnotetext{
${ }^{35}$ Herbert Anstice, Letter to Mabel, 5 Sept 1918, in Anstice Family, Herbert Anstice - Correspondence, 1918-1919, MS-Papers-5164-08.

${ }^{36}$ Anstice, Letter to Mabel, 7 May 1918.

${ }^{37}$ Mabel Anstice, Letter to Herbert Anstice, 12 May 1918, in Anstice Family, Letters from May Anstice to her husband, Bert, 1918, MS-Papers-5535-04, ATL.
} 
however I will hope for some leave so that I can get home'.$^{38}$ Bert clearly felt worried that Mabel had to cope with any parenting problems on her own.

Their daughter, who was in her first year for most of Anstice's time away, was Mabel's main concern and the subject of many of her letters. In one letter she recounted her daughter crying “"Dada, Dada,"' and opined 'I'm sure you heart would have melted if you could have heard her'. ${ }^{39}$ The separation between father and daughter clearly affected Margy to some extent despite her young age, and led to Mabel having to deal with any issues on her own. It is clear that Mabel hoped Bert would get to know Margy better and love her as she did. On one occasion she wrote 'She is such a sweet tempered happy little soul, I know that you will fall in love with her when you come home' ${ }^{40}$ This shows that Mabel felt Bert did not know Margy well due to the separation. She also wrote of missing Bert at home, writing 'I have missed you the last two nights. It is so nice to have someone to sleep with' ${ }^{41}$ She also wrote that she was '...just longing for you....Baby is very dear, but you are even more so' ${ }^{42}$ His companionship at night was very important to her, and she noted once more 'I am alone again tonight....I do miss you so much as you were always at home in the evenings. ${ }^{43}$ The lack of adult company that Mabel experienced at times was difficult for her, and she clearly missed the intimacy that she shared with Bert. She also noted that he was missing Margy growing up, and it is clear that he was not as close to the child as she desired. Her hope that Bert would 'fall in love' with Margy shows the great effect that the separation was having on the father-daughter bond.

\footnotetext{
${ }^{38}$ Herbert Anstice, Letter to Mabel, 28 July 1918.

39 Mabel Anstice, Letter to Bert, 13 August 1918, Anstice Family, in Letters from May Anstice to her husband, Bert, 1918, MS-Papers-5535-05, ATL.

${ }^{40}$ Mabel Anstice, Letter to Bert, 3 August 1918, MS-Papers-5535-05.

${ }^{41}$ Mabel Anstice, Letter to Bert, 13 September 1918.

42 Mabel Anstice, Letter to Bert, 19 August 1918.

${ }^{43}$ Mabel Anstice, Letter to Bert, 7 May 1918, MS-Papers-5535-04.
} 
The ache for home often showed itself in letters, whether they were written to lovers or to family members. Bert Stokes relates this in his writing to his parents, stating that 'Hardly a moment passes by that my thoughts fly homewards....Let's forget about war and think of Blighty and of home. ${ }^{44}$ For Stokes, the imaginings of home and of his trip to England were what took his mind off his war experiences. Stokes wrote while in England,

amid all these sights, historical and wonderful there is always high above everything...the thought of home beyond the seas, the little Islands of the Southern Seas, the land of home and beauty. Home love is where the heart is, and I never forget you all at home. I am always thinking of you as you are of me. ${ }^{45}$

Stokes' poetic language conveys his feelings about home and serves as a reassurance to his family that he was thinking of them, despite having very good experiences in England. Arthur Pounteney used his thoughts of home to reassure his wife that he was not spending his time in bad company, noting 'you may rest assured I can pass away my few spare moments, scheming out and planning our future happiness after the war. Do not be alarmed about "Temptation Square". ${ }^{46}$

Lionel Crowley's thoughts of home concerned both his future and his family. In one letter he stated that 'I am always wondering how you are getting on \& only hope to blazes that the old war will finish soon'. ${ }^{47}$ In another, he noted 'I'm always thinking of you \& am looking forward to the time, when l'll be able to enjoy life once more with you all. ${ }^{48} \mathrm{He}$ was clearly fond of his family. Crowley's longing for home also led him to opine that he would never leave again, writing 'I know I am longing to get back to the

\footnotetext{
${ }^{44}$ Stokes, letter to his parents, 19 November 1917.

${ }^{45}$ Stokes, letter to his parents, 16 January 1917.

${ }^{46}$ Pounteney, Letter to Emma, 1 April 1916.

${ }^{47}$ Lionel Crowley, Letter to parents, 15 May 1918 in Crowley Family, Letters, 1917-1919 MS-Papers4131, ATL.

${ }^{48}$ Crowley, Letter to parents, 23 August 1918.
} 
old show, believe me, nothing will ever shift me, once I do get there. ${ }^{49}$ Here Crowley's happy memories of his life at home formed his vision for the future, so much so that he had no desire to be away ever again, something which may have changed on return. After the end of hostilities Crowley wrote from Germany 'Jove, how I'm looking forward to the day when I'll hit that one \& only City of Tauranga again. I think I'll just about go mad the first few months' ${ }^{50}$ He also enquired after the family farm humorously asking 'Does Mum still run away from the cows? ${ }^{51}$ His interest in farming formed his postwar ambitions to work on the family farm, and he had a change of career in mind. When his father went on the farm, Crowley wrote 'So Dad is going on the farm for good....hope you make a great success of it. I'll be right with you, when I return, no more clerking'. ${ }^{52}$ He reaffirmed this in a later letter, writing 'Wait till I get back, you can count on me to go in for farming, office work is a complete washout for this chicken. ${ }^{53}$ The return home for Crowley was an exciting prospect, not only because he was able to see his family, but also as the beginning of a career change. In this case, Crowley wasn't so much longing for his pre-war life as impatient to begin his post-war life and career change, and he was very keen to get back to his hometown and family.

For some men, mentions of home and the future were more brief or sparse, but meaningful nevertheless. Roy Mowat, in his letters home, wrote mostly about his experiences at the front and the horrors of war that he saw around him. However, his musings about the future came out in two letters, in brief comments. In one letter to his mother he noted that 'I would love to be home for a while to see you all', and that

\footnotetext{
${ }^{49}$ Crowley, Letter to parents, 23 August 1918.

${ }^{50}$ Crowley, Letter to parents, 28 Dec 1918.

${ }^{51}$ Crowley, Letter to parents, 23 August 1918.

52 Crowley, Letter to parents, 15 May 1918.

${ }^{53}$ Crowley, Letter to parents, 12 June 1918.
} 
he 'Would like to be back in NZ for the start of next shearing'. ${ }^{54}$ He also notes in the same letter 'Hastings \& self often say that if we get back we will go straight down the sounds \& get away from war \& war talk' ${ }^{55}$ His musings on the future are brief, but what is clear is that he wishes to see his family, return to work, and clearly is sick of war. His shared idea that he would like to go somewhere secluded on return show his urge to be away from war in every way. In a later letter, in his typically brief style, he states 'Only hope that I will be able to spend a xmas with you one of these times'. ${ }^{56}$ Again, his longing for home comes out in a brief statement; his sense of an unknown future also emerges in his use of 'one of these times'. Mowat's letters are brief and written in a sparse style, yet his wish to be home again and to see his family come across clearly. Hugh Cleland's letters were similarly preoccupied with happenings at the front and home; however, in one letter Cleland noted

It's about ten months since we left N.Z. I thought we would have been back almost by then.... only wish we were all on our way home, but suppose we will have to see it out, it might finish sooner than we think.... Well dear I often think of the time, we have had together.... It seems ridiculous having to live lives like this when there's no occasion for it. ${ }^{57}$

His relatively short time away from home may have led to him not expressing such feelings more often, however, this extract shows that he misses Lily - it is not clear what the nature of their relationship is - and that he wants to return home. He is not explicit on his reasons for wanting to return; yet his comment on 'lives like this' suggests that he dislikes military life and war, and much prefers home.

\footnotetext{
${ }^{54}$ Roy Mowat, Letter to Mother, 20 July (unknown year), in Mowat, Roy Letters, 1914-1918, MS-Papers7496-06, ATL.

${ }^{55}$ Mowat, Letter to Mother, 20 July (unknown year).

${ }^{56}$ Mowat, Letter to Mother, 10 November 1917.

${ }^{57}$ Hugh Cleland, Letter to Lily, 7 August 1918, in Cleland, Hugh, Letters to Lily, Jul 1917-Mar 1919, MSPapers-2340, ATL.
} 
Most of these fantasies of the future and reminiscences of the past focus on home life and life with loved ones. The bias of the surviving letters of the war is towards this due to the survival of war letters between those who remained close after the war. Furthermore, women's desires for returning men included being a family again, and in Mabel Anstice's case, this comes through clearly in her anxieties over Bert's bond with their daughter, Margy. For women in Mabel's position, the resumption of their returned man's role as a husband and father were very important; some families suffered years of separation, and some returned soldiers had children they had never met or had only spent a very small amount of time with, like Bert and Margy. Once the relief of the war's end and their loved ones' safety had sunk in, it is likely that many thought about family reunion, which in some cases, held these complications. Yet what is clear in all of these letters is that these men desired to be with their loved ones and families again, and these were the bonds that often helped a returned man reintegrate into society more successfully. Family was one of the first ports of call when returning men needed various kinds of support, and it is clear that many men had strong family bonds that were resumed on return.

For those who did not already have a family, marriage was often an aim for many returning from war. Records show that many soldiers married immediately or very soon after return from war. The overall marriage rate surged in 1919, with this attributed to the return of men from overseas. ${ }^{58}$ Compared to 6,227 marriages in 1918, there were 9,519 marriages in $1919 .{ }^{59} \mathrm{~A}$ further increase in marriages occurred in 1920 , with 12,175 marriages being solemnised, again attributed to the return of

\footnotetext{
${ }^{58}$ New Zealand Government, Vital Statistics, Marriages, 1924, p.119.

${ }^{59}$ Vital Statistics, 1924, p.119.
} 
soldiers. ${ }^{60}$ Lower marriage rates of 10,635 and 9,556 occurred in 1921 and 1922 respectively. The trend of a high rate of marriages continued in 1921, but was then slowed by the economic downturn. ${ }^{61}$ The rates recovered in 1923 , with 10,070 marriages occurring. ${ }^{62}$ What can be taken from these statistics is that marriage was often one of the first priorities when returning from war. Many men held back from marriage if they felt they were not financially stable, and this is shown in the decline of marriages in 1921 and 1922, during the economic downturn. Marriage was one element of stability in returned men's lives, giving them emotional support and the ability to start a family and settle down. This ties into the importance placed on emotional ties that reveals itself in men's writings from the front. The urge to settle down is an obvious manifestation of the realised importance of family and loved ones. In oral history interviews undertaken in later life, soldiers emphasised employment as a key aspect of successful repatriation. Lionel Crowley's enthusiasm to start his career on return was doubtless shared by many others, and the ability to undertake this allowed soldiers to move on with their lives. Employment gave the freedom to marry and settle down.

When men were finally able to return home, some men found that their lives took unexpected turns. Other men returned and were able to resume their pre-war jobs, such as Bert Anstice, or take up new employment; some men got engaged, married, such as Lindsay Inglis, or met their future wives on return. Many returned soldiers did not have an overly difficult time when they rebuilt their lives in New Zealand. It is important to recognise the ways in which many returned men succeeded in resuming their lives without great effect from the war to understand why there

\footnotetext{
${ }^{60}$ Vital Statistics, 1924, p.119.

${ }^{61}$ Vital Statistics, 1925, p.127.

${ }^{62}$ Vital Statistics, 1925, p.127.
} 
were some men who did not. Some examples of the lives men were able to live after the war are documented in the interviews with World War One soldiers in the National Library.

One interview account is that of Colin Gordon. His interview highlights the dislocation of moving from the extremes of war and peace which caused problems when returning. Even some of the most simple adjustments - such as being able to wear civilian clothing - took time. For returned soldier Colin Gordon, the shedding of his uniform was symbolic and powerful. He explains that

I didn't have any clothes at home to change into, I still had to keep on my uniform. And the day after I got home...I went down with my brother to Ballantynes to get a suit of clothes made....And I couldn't wait to get them. They arrived in a few days.... w was able to get out of uniform, and never had it on again. I'd finished with the army and glad to see the last of them. ${ }^{63}$

Gordon faced the frustration of not being able to dress in his own clothing, which was particularly important to him given that he no longer wanted any connection with the army - the shedding of his uniform was a very important part of this process. Arthur Emmins describes his return in terms of his newly found freedom also:

...when I first came back I didn't do anything for about three months. Getting used to being home. Like in the army you get up in the morning at the right time, you go to bed at the right time, and...everything is regimental. Well when you come home and you get rid of all that you're glad of...the freedom. ${ }^{64}$

Emmins was fortunate to be able to relax and readjust for a reasonable amount of time, which included not having to find a job straight away.

\footnotetext{
${ }^{63}$ Colin Gordon, interview by Jane Tolerton and Nicholas Boyack, 12 September 1988, for the World War I Oral History Archive, held in the Oral History Centre, ATL, OHC-002640.

${ }^{64}$ Arthur Emmins, interview by Jane Tolerton and Nicholas Boyack, 21 September 1988, for the World War I Oral History Archive, held in the Oral History Centre, ATL, OHC-002622.
} 
One of the important differences that successful men had in their favour was a job on return, or the ability to undertake study. The ability to recommence employment relatively quickly undoubtedly added an element of stability to life, including the routines necessary to working life. The security of paid employment provided the ability to live more comfortably and potentially to start planning for the future. Some men felt that to consider marriage at this time, financial security was a must - for interviewee Les Harris, this was the case ${ }^{65}$ Certainly this was seen as more important in a society where married women were not likely to go out to work. Therefore the key to many men's future happiness was employment. Lastly, employment allowed for the engagement of the mind, and the ability to socialise with a wide range of people, both of which were healthy ways for returned men to move on from their war experiences. With their minds occupied, there was less time for thoughts of the war, particularly of the horrors that they had witnessed and the hardships that they had endured.

Economic conditions in New Zealand after the war worsened; the economy suffered after the prosperity of the war years and the end of the commandeer system, in which Britain guaranteed high prices for a monopoly on primary New Zealand exports. The resulting depression hit fully in 1921, leading to high unemployment, bankruptcies, and difficulties for farmers whose products had, up until then, been sold for very good prices, and whose land plummeted in value. ${ }^{66}$ All of these factors affected returned men and their luck with employment or farming. However, some men were able to prosper under such conditions.

\footnotetext{
${ }^{65}$ Les Harris, interview by Jane Tolerton and Nicholas Boyack, 7 August 1988, for the World War I Oral History Archive, held in the Oral History Centre, ATL, OHC-002646.

${ }^{66}$ Tom Brooking, 'Economic Transformation', in Geoffery Rice (ed.), The Oxford History of New Zealand, Auckland, 1992, p.231.
} 
The veterans interviewed could see the link between settling down and obtaining a job. When interviewee Wilfred Davies was asked whether he found it difficult to settle down, he replied 'No. [1] Went back to the scene of my former crimes, working on the station. ${ }^{67}$ He noted that soldiers who found it difficult to settle down 'couldn't get jobs. I just happened to be a good servant. My job was waiting for me when I got back. ${ }^{68}$ Another interviewee, James Bisman, considered the difficulties of soldiers settling in post war, and stated that 'I suppose some of them found it difficult. It didn't concern me a great deal...I had a job, my job was there. ${ }^{69}$ Here Bisman emphasises the importance of having his job - it was a foundational requirement for security, and for settling down. It also gave men a sense of normality as they returned. Frank Jamieson's job at the Lands Department in Auckland was kept open for him while he was at war, due to it being in the public service. ${ }^{70}$ Despite this, he considered going on the land, but was advised by his medical officer to go back to his old job for six months. This choice proved to be a wise one - Jamieson describes that in six months time the price of produce had slumped, butter fat...went to about eighteen pence. And all the glamour had gone out of going on the land. ${ }^{71}$ Jamieson was lucky enough to be confronted by a choice of occupations to follow once he returned; and his choice to stay in his job potentially helped him to settle down more than choosing to go on the land would have, as he did not face the financial instability that many soldier farmers did. Being unsettled could also be tied to the inability to decide what to do as a job. Benjamin Gainfort was one returned soldier who felt very unsettled on

\footnotetext{
${ }^{67}$ Wilfred Davies, interview by Jane Tolerton and Nicholas Boyack, 4 December 1988, for the World War I Oral History Archive, held in the Oral History Centre, ATL, OHC-002607.

${ }^{68}$ Davies, OHC-002607.

69 James Bisman, interview by Jane Tolerton and Nicholas Boyack, 4 December 1988, for the World War I Oral History Archive, held in the Oral History Centre, ATL, OHC-002560.

${ }^{70}$ Frank Jamieson, interview by Jane Tolerton and Nicholas Boyack, 4 December 1988, for the World War I Oral History Archive, held in the Oral History Centre, ATL, OHC-002668.

${ }^{71}$ Jamieson, OHC-002668.
} 
return; when asked he stated that he 'Didn't know what I was going to do'. ${ }^{72}$ He had a number of jobs post-war, and these were mainly labouring jobs, which were of a more transient nature and also offered little in the way of security. ${ }^{73}$ If labouring work was undertaken on a casual basis, there was every chance that men who were employed in this manner could find themselves unemployed at various points.

Education, and having the means to undertake it, was a key element in job success when establishing oneself post war. Colin Gordon was able to undertake training as an accountant, a profession he chose because

I didn't feel up to settling down to at least 2 years swotting law before I could qualify, whereas I thought I could qualify as an accountant in lesser time....so I made arrangements with a commercial college in Christchurch. ${ }^{74}$

Gordon's ability to study instead of having to find work straight away was partly due to help extended to him by the Canterbury Patriotic Society, which was provided throughout his studies until he obtained a job. This help clearly meant a lot to him, as he returned to the society 30 years later and made a donation as thanks for the funds they gave him. ${ }^{75}$ He does not mention if he received financial help from his parents. Help from patriotic societies would have made quite a difference in many soldiers' lives if they were trying to study or follow other pursuits. There were benefits to studying during the tough economic conditions during the early 1920s, simply due to not having to search for a job, a predicament that led many men to take up farming. The specific and vocational training that Gordon undertook potentially made him more

\footnotetext{
${ }^{72}$ Benjamin Gainfort, interview by Jane Tolerton and Nicholas Boyack, 1 November 1988, for the World War I Oral History Archive, held in the Oral History Centre, ATL, OHC-002627.

${ }^{73}$ Gainfort, OHC-002627.

${ }^{74}$ Gordon, OHC-002640.

${ }^{75}$ Gordon, OHC-002640.
} 
employable then men who returned with few skills; it also gave him the ability to be self employed later in life.

Employment and marriage were very much linked to one another, for a returned soldier was unlikely to marry without seeking employment first. For Frederick Dill and Les Harris, the desire to be married meant they had to find employment. This led them to take up farming on return. Contrary to the popular view not all soldier farmers were unsuccessful. Some soldier settlers took up farms on return via the government scheme; others took over family farms and were able to make these succeed due to the fact that they were not mortgaged to the government, and perhaps were able to buy land for more reasonable prices. Frederick Dill took over his mother's farm after his return from war and his marriage. Dill was wounded at war, and spent some time at home recovering. He was planning to take over the family farm, so he was able to stay with his mother on the farm during his recovery rather than having to find employment. He stated that 'I wasn't terribly fit. I just sat around I suppose, and gradually got a bit better and wandered about the farm ${ }^{76}$ For Dill, this healing time was important. He notes that he 'wasn't good to do a day's work or anything like that. ${ }^{77}$ The fact that he delayed his marriage and taking over the farm for 18 months shows the amount of time it took him to feel ready to take on the farm. Dill's inability to work during this time meant, for him, that it would not be appropriate to be married. Dill did not seem to have any lasting effects from his war injuries, which would have been the case for a number of injured or ill men returning from the front. The farm was 'mixed...in those days it was mostly dairy...but it had quite a few sheep

\footnotetext{
${ }^{76}$ Frederick Dill, interview by Jane Tolerton and Nicholas Boyack, 29 September 1988, for the World War I Oral History Archive, held in the Oral History Centre, ATL, OHC-002612.

${ }^{77}$ Dill, OHC-002612.
} 
and a lot of cattle'. ${ }^{78} \mathrm{He}$ remembered that his mother had 'a big part of the mortgage on it' which he credits with his ability to keep the farm in tough economic times. ${ }^{79}$ One of these times was in 1921, which Dill stated was a 'very tough year on the farm....we were pretty hard up. ${ }^{80}$ Dill's farming ability may have been a factor in his making a success of the farm. Dill states that throughout his life up until the end of the war that he had 'always had the goal to be a farmer' ${ }^{81}$ His mother owned the farm too which would have given Dill ample opportunity to work on it and learn farming skills. This gave Dill an advantage over many of the men who took up settlement farms, as the government did not have strict criteria on how much farming experience was needed.

Another successful farmer was Les Harris, who was gassed during the war and was told that he could not go back to his old job as a blacksmith. His doctor warned him that if he did so, 'I'd give you six years' to live'. ${ }^{82}$ Harris stated that 'It put the wind up me for a while, l'll tell you. ${ }^{83}$ Harris clearly did not expect that his gassing at war would have such serious implications for his health and working life. Yet he was able to find an occupation that allowed him to continue physical work but without the dangers for his health that being a blacksmith held. Despite his successes with farming, Harris did find that the lack of money held him back - particularly in his personal life. He met his future wife while at war, but she lived in Scotland. Harris explained that his money situation stopped him from marrying his wife until 1926 when she was able to join him in New Zealand, stating that 'If I'd had the money we'd have married [in Scotland]....you want to have something to go on with, so I borrowed the money for

\footnotetext{
${ }^{78}$ Dill, OHC-002612.

${ }^{79}$ Dill, OHC-002612.

${ }^{80}$ Dill, OHC-002612.

${ }^{81}$ Dill, OHC-002612.

${ }^{82}$ Harris, OHC-002646.

${ }^{83}$ Harris, OHC-002646.
} 
the farm. ${ }^{84}$ Harris decided to borrow money privately and bought a farm at Ashley, in Canterbury. He stated that the farm 'did quite good' ${ }^{85}$ He did struggle through the 1921 depression - he reflected that 'I had very little money but I managed to scratch through. ${ }^{, 86}$ He was later able to sell this farm and lease another farm, which he had stayed on until the 1980s. Harris clearly felt that he needed to get on his feet in New Zealand before his future wife could join him. The uncertainties that men faced on return in terms of employment and money could hold them back from marrying and settling down, simply due to a lack of financial security. For Harris, this meant that he was unable to marry his fiancée for a number of years; yet once he did he was in a good position financially with his new farm, which gave them a better chance at a financially stable life.

Men who returned with injuries often found life more difficult, and in many cases it was merely circumstance that led to some returned men having better luck establishing themselves than others. For example, as will be discussed in chapter four, TB men's lives were marred by their illness, which often held them back from being able to be employed or participating fully in familial relationships, or spurred life changes that were not successful. Yet men who sustained injuries at war often were able to rebuild their lives on return. Francis Fougere sustained a reasonably serious arm injury while at war, and was sent back to New Zealand. On return, he received effective treatment and was not discharged from the army, so was still quite secure financially. He explains his lifestyle at this time:

I went to Rotorua for massage treatment for quite some time, some months, and as I've said I went into different hospitals, I just knocked about the

\footnotetext{
${ }^{84}$ Harris, OHC-002646.

${ }^{85}$ Harris, OHC-002646.

${ }^{86}$ Harris, OHC-002646.
} 
country....I went into whatever hospital was handy when an abscess would form on my arm and l'd be there for...maybe a week or so....A piece of bone would come loose from the main bone and cause me trouble. And then, when they did discharge me eventually, I was cured. ${ }^{87}$

Fougere had a reasonably painful and recurring condition, but with treatment, was able to regain use of his arm. This allowed him to take up a farm under the soldier settlement scheme, and he took what he describes as '1000 acres of standing bush' which was largely virgin forest; only a small patch of the farm had been cleared, where the surveyors had their camp. ${ }^{88}$ Taking on such a lot of work with a weakened arm could be seen as a gamble; however, for Fougere, it paid off. When asked how he managed to do farm work with his arm injury, he stated bluntly 'I just worked away and it gradually got some strength into it and became stronger and stronger, and I managed quite well. It's been a handicap, certainly, but it has been quite strong' ${ }^{89}$ At the time of the interview, Fougere was still receiving a pension for his arm, showing that it was a long lasting disability. In this case, Fougere was lucky to have good treatment, a manageable injury, and the ability to make a success of his settlement farm. His arm injury, while a 'handicap' to him, was healed enough to allow him to live out a normal life which involved a large amount of labour - Fougere admitted that it took him thirty years to clear 800 acres of his farm, which he was then able to sell on. ${ }^{90}$ Presumably he did a lot of this clearing himself, although he could have potentially hired labour. Fougere's story is a mixture of luck and perseverance, and undoubtedly echoes the stories of hundreds of other soldiers who returned with disabilities and had to learn to work around them.

\footnotetext{
${ }^{87}$ Francis Jude Fougere, interview by Jane Tolerton and Nicholas Boyack, 8 November 1989, for the World War I Oral History Archive, held in the Oral History Centre, ATL, OHC-002624.

${ }^{88}$ Fougere, OHC-002624.

${ }^{89}$ Fougere, OHC-002624.

${ }^{90}$ Fougere, OHC-002624.
} 
The experiences of the men interviewed are ones of successful repatriation. While these men did not necessarily have easy experiences, they were able to work through their difficulties and build secure post-war lives for themselves. Their ability to do so stemmed from a number of circumstances, some of which were personal choices; others were not in their control. Some men returned home to find that they were able to resume their pre-war occupations with ease; others, who were not, had the financial support to pursue other ventures or to take some time off to think about what they were going to do. For those men who took up farming, some were able to pull through very hard times on their farms; again, this could be due to better financial backing, or simply luck in the resources they had to draw on in difficult circumstances. Those who returned with injuries were either fortunate enough to have good treatment and be cured, or to be able to take time to recover from their injuries and work around them in later years. Again, the circumstances of these injured men were dependent on financial support and the extent of their injuries - those with less serious, recoverable injuries were likely to be able to live relatively normal lives. These soldiers' post-war experiences led to better outcomes for many reasons, but main themes in these soldiers' stories were the ability to get a job or be financially supported, good treatment of war injuries and the ability to rest these injuries and recover for a period of time. These factors, combined with chance and what some would call luck, led to these men having secure futures.

Wartime dreams and fantasies highlighted the importance of emotional connections while away. Thinking about employment was less common among soldiers, with letters emphasising reuniting with family and lovers and making plans for the future in terms of this. Soldiers also saw New Zealand as a safe haven, and civilian 
life there as untroubled and uncomplicated. When writing of home, the comforts that they had taken for granted came to mind often and were deeply appreciated. New Zealand was perceived as a secure place that many men felt held their happiness. The dreams of men at the front and fantasies of home could, however, differ dramatically from the reality of life at home at the end of the war. Many things had changed over the course of the war, and many of these were out of the control of the men. Up to four years of separation led to a number of changes occurring in society, within families, and to individuals and their lifestyles. Men wanting to settle down and move on with life could find such plans scuppered by many factors. The economy went downhill quickly in 1921; that very first step of finding a job could be very difficult, and alternatives such as farming soon proved to be less than successful for many men. Oral history interviews conducted with veterans emphasise employment as a key factor in successful repatriation. Family support was still important, however, with men citing the emotional and financial support of their families on return as a great help. In these men's recounting of post war reintegration, emotional security and financial stability was also entwined in terms of men ensuring they had employment before getting married. Yet despite the difficulties that men faced, there were those who were able to build their lives and move on to secure futures. A large number of men returning from war settled into civilian life and resumed it with relative ease. For these men, it was a number of circumstances that allowed this to happen, many of which were a matter of chance. The following chapters illuminate the lives of those who did not repatriate successfully. These men did not necessarily do anything wrong; some returned from war in less advantageous positions, from less wealthy backgrounds and with less financial support, with severe illnesses or injuries. They also may have made choices that affected their future negatively, or were victims of the economy and of 
societal changes. Their stories stand in contrast to those who did repatriate successfully, highlighting the differences between these experiences. The following chapter demonstrates that, as well as individuals, the Army and the State also understood that employment was crucial to the stability of the post war world. 


\section{Chapter Two: Employment and Soldier Settlement}

Well I said I'm a blacksmith and I can go back to my trade, I said. And he said 'inside?' and I said yes, and he said 'You'd be foolish.' And I said 'Why?' and he said 'Well the state your lung is in now, and with the dust in a foundry, I'd give you six years.' To live. ${ }^{1}$

- Les Harris, 1988.

Employment was an essential part of adult male life in the early twentieth century. The war had interrupted employment and training for approximately 1 in 4 men. $^{2}$ Unsurprisingly regaining employment was a preoccupation for many returned men. For those without jobs to go back to, there appeared to be many options; for many the return was the time for a fresh start. However, the reality for those who were jobless was often grim. Jobs were difficult to get, or were short term, leaving returnees facing uncertain futures. Many men returned unable to do physical work, which meant that they had to compete with hundreds of others for office work. Women and foreigners were targeted as threats to returnees' chances of employment. This, coupled with the large number of men returning, some of whom had decided on career changes or who had been previously unemployed or studying, made for anxiety and anger over the unemployment problem. The inability to find a job held men back from being able to move on with life, particularly affecting men's wishes to get married and start families. Financial stability was seen as a requirement for this, and some men put their emotional lives on hold while improving their financial situations. Instability and insecurity became part of many men's lives as they either failed to find employment or were only able to find temporary work. Such circumstances increased the attraction of

\footnotetext{
${ }^{1}$ Les Harris, interview by Jane Tolerton and Nicholas Boyack, 7 August 1988, for the World War I Oral History Archive, held in the Oral History Centre, ATL, OHC-002646.

${ }^{2}$ Report from Department of Labour, Appendix to the Journal of the House of Representatives, (hereafter AJHR) 1918, Vol.2, H-11, p.1.
} 
soldier settlement. The programme allowed men who often had very little farming experience and money to purchase farms from the government, and progressively pay these loans back as they made profits on the farms. For those returning from war facing unemployment, and for those who desired to settle down, this scheme seemed like a very good idea. However, the settlement scheme ran into problems; soldier inexperience, inferior land quality, lack of money and indebtedness, and an economic downturn which slashed farm profits all led to many soldiers struggling or having to walk off farms. This chapter analyses the problems faced by returned men seeking employment, government attempts to ease the problem, and soldiers' feelings and perceptions of the crisis. It will also explore the problems with the soldier settlement programme and the experiences of men who undertook farming through this. Overall it shows that the difficulties that men faced on return often shattered the dreams that they had for their post-war lives. Employment was an important milestone in repatriation, one that gave soldiers the financial freedom to chase some of their dreams, and to have this go unrealised was frustrating and in some cases catastrophic for men and their families.

The Caversham Project can give some insight into the makeup of occupations and attitudes to work in the wartime and post-war era. This project, which analysed the community of Caversham Borough in Dunedin can be used as a sample of the occupations in which men were working in the early 1900s, and therefore what kinds of employment they were seeking after the war. Firstly, the emphasis on male breadwinning cannot be overstated. Erik Olssen, who instigated the Caversham Project, states that by 1914 , 'most married men in New Zealand considered it a 
humiliating confession of their inadequacy if their wives had to accept paid work' ${ }^{3}$ Respectability was measured by a wife's ability to stay home; this was due to ideas of 'respectability and the ideal life'. ${ }^{4}$ Women made up 26.12 percent of the total workforce by 1926 , as opposed to 27.72 percent in $1901 .{ }^{5}$ Male wages were set at a rate that was meant to be able to support a family without the wife working. Therefore, for returned men with families, or those wishing to marry, a job was of the highest importance. Failure to obtain one could be a shameful experience for men. It is also important to note that New Zealand was largely an agricultural economy at this time, explaining the popularity of the soldier settlement scheme. However, the workforce at the beginning of the 1920s was changing. Workers were moving away from jobs in the primary sector - that is, jobs in agriculture, forestry, hunting, fishing and mining - into jobs in the tertiary sector, jobs in finance, transport, storage, communications and trade. ${ }^{6}$ The secondary sector - manufacturing, utilities and construction - also employed more workers, though not on the same scale as the tertiary sector. ${ }^{7}$ White collar work became increasingly popular, with 17.79 percent of male workers employed in this way by 1926 , up from 12.61 percent in $1901 .^{8}$ The most popular occupations were those of skilled workers, which grew from 21.39 percent of the workforce in 1901 to 27.59 percent of the male workforce by 1926 , and included occupations such as electricians, linesmen, bootmakers, carpenters, and painters as well as any occupation that involved making a product (for example boatmakers or

\footnotetext{
${ }^{3}$ Erik Olssen, 'Working Gender, Gendering Work', in Barbara Brookes, Annabel Cooper, \& Robin Law (eds.), Sites of Gender: women, men and modernity in Southern Dunedin, 1890-1939, Auckland, 2003, p.60.

${ }^{4}$ Olssen, 'Working Gender, Gendering Work', p.60.

${ }^{5}$ Erik Olssen \& Maureen Hickey, Class and Occupation - The New Zealand Reality, Dunedin, 2005, p.96

${ }^{6}$ Olssen \& Hickey, Class and Occupation, p.98.

${ }^{7}$ Olssen \& Hickey, Class and Occupation, p.98.

${ }^{8}$ Olssen \& Hickey, Class and Occupation, p.101.
} 
pianomakers). ${ }^{9}$ This shows that skills - either clerical, or in a trade, were important in the workforce at this time. However, unskilled occupations also soaked up a large percentage of the workforce - 20.89 percent of the male workforce in 1926, which had dropped from 27.28 percent in $1901 .{ }^{10}$ The census definition of "unskilled" hides the occupations that it encompassed. Some examples are waterside workers, barmen, milkmen, employee labourers, freezing works employees, road workers, and undefined types of labourers in various trades. ${ }^{11}$ This shows that for those who did not have a particular skill or clerical training, there were still many options; however, not all men would have wanted to undertake this kind of work, whether due to wage rates or their body's limitations.

In the years following the war, economic conditions quickly deteriorated. This fed into further problems with employment, compounded by the problem of approximately 52,000 men who were repatriated between 1918 and the end of 1919, many of whom were seeking employment and therefore competing with one another for jobs. ${ }^{12}$ New Zealand faced an economic downturn in 1921 that drove unemployment even higher and caused many bankruptcies. The 1920 s became a time of 'widespread disillusionment and political instability as well as economic insecurity'. ${ }^{13}$ The downturn in 1921 led to years of recession and recovery which were finally ended by the Great Depression of the 1930s. The cause of the 1921 downturn was partly an end of the prosperity that had accompanied the Great War boosted by British price and sale guarantees for meat, wool and dairy products (also known as the

\footnotetext{
${ }^{9}$ Olssen \& Hickey, Class and Occupation, pp.101, 200-217.

${ }^{10}$ Olssen \& Hickey, Class and Occupation, p.101

${ }^{11}$ Olssen \& Hickey, Class and Occupation, pp.224-237.

${ }^{12}$ Michael Wynd, "So the end has come- I shall see you all again': demobilising the New Zealand Expeditionary Force, November 1918-September 1919', MA Thesis, Massey University, 2006, p.161.

${ }^{13}$ Brooking, 'Economic Transformation', p.231.
} 
commandeer system). This ended in $1921 .{ }^{14}$ This focus on exports as a source of wealth and prosperity in New Zealand up to the 1920s explains both the emphasis on farming for soldiers on return and the difficulties for those returning to wage-earning professions, which suffered further due to the economic conditions.

It was obvious however well before 1921 that the future would be a difficult time for returned men seeking employment. A 1917 memorandum to G.W. Russell, the Minister of Internal Affairs, from the Discharged Soldiers' Information Department stated:

It must not be forgotten however that we are only at the beginning of our trials. The disbandment of the forces on the cessation of hostilities will throw great numbers of men on the labour market and personally I shall be greatly surprised if there is not a considerable amount of real unemployment. ${ }^{15}$

Gwen Parsons notes that the Repatriation Department placed 27,658 veterans in employment in its three years of operation (1919-1922), through the work of regional volunteer Repatriation Committees. ${ }^{16}$ Some of this employment was temporary, including public works projects that the government provided for some of the labour force. ${ }^{17}$ Yet this department closed in 1922, with the Government feeling that it was no longer needed. This approach, given the economic conditions that prevailed in the 1920s, worsened the plight of unemployed soldiers.

Employment problems especially affected younger men who had gone to the front before they could take up apprenticeships or go to university. The government responded to this accordingly, making exceptions for returned soldiers. Questions

\footnotetext{
${ }^{14}$ Brooking, 'Economic Transformation', p.231.

${ }^{15}$ Memorandum to G.W. Russell, Minister of Internal Affairs, 25 April 1917, in Returned Soldiers: Re Medical Examination on Entering Public Service: 1917-1919, AATJ GS 5/8/2 11, Archives New Zealand.

${ }^{16}$ Gwen Parsons, "The Many Derelicts of the War'? Great War Veterans and Repatriation in Dunedin and Ashburton, 1918-1928', PhD, 2008, Otago University, pp.89, 91.

${ }^{17}$ Parsons, "The Many Derelicts of the War'?', p.91.
} 
were raised in 1917 over the possibility of relaxing the need for the Junior Civil Service Examination to be sat for entrance into the clerical division of the Public Service. It was thought that this could be waived for returned men in lieu of 'a satisfactory period of probation' ${ }^{18}$ Giving returned men this option meant that men who had been away from home at a time of their lives when they would have been studying or moving into the workforce were able to make up for this loss of opportunity. This was also considered an option for men wanting to work in the Railways Department. The Defence Department's vocational officer made enquiries as to the possibility of men being able to obtain a 'returned soldiers' pass' in the subjects needed, rather than having to sit for a proficiency pass. ${ }^{19}$ This returned soldiers' pass was meant to show that the soldier was proficient in these subjects and would save time in having to study for another certificate. The Railways Department decided that returned men could be qualified for a $5^{\text {th }}$ standard certificate to work there, and if the education board was prepared to certify that a returned man was qualified to this standard, then this would be satisfactory. ${ }^{20}$

Lack of qualification also concerned many younger men who enlisted during the war and left behind uncompleted apprenticeships or university studies. This led to some uncertainty on return for those who had been apprentices with the question of whether they could complete their interrupted training. Those who had university studies interrupted also faced this issue. The Defence Department responded to this worry in a report to the Government in 1919 in which it stated that apprentices had

\footnotetext{
${ }^{18}$ Memorandum to G.W. Russell, 25 April 1917, AATJ GS 5/8/2 11, Archives New Zealand, Wellington.

${ }^{19}$ Letter to Director of Vocational Training, 3 July 1919, in Public Service Employment of Returned Soldiers, April 1919-August 1919, AD 877 VA/103/30, Archives New Zealand, Wellington.

${ }^{20}$ Letter to Director of Vocational Training from R. McVilly, General Manager Railways Department, 5 August 1919, in Public Service Employment of Returned Soldiers, April 1919-August 1919, AD 87 VA/103/30, Archives New Zealand.
} 
generally been able to resume their apprenticeships and that the Defence Department was subsidising the wages of those who had done so up to $f 3$ a week, therefore making a return to apprenticeship more attractive. ${ }^{21}$ Apprenticeships in general were less popular by 1920 than before the war, with both low pay and the de-skilling of the workforce blamed. ${ }^{22}$ The use of machinery in production reduced the need for skilled workers. In New Zealand the wage rates for unskilled workers were the same or higher than skilled workers, meaning that the incentive to learn a trade was low unless the prospective trainee had a strong interest in that subject. ${ }^{23}$ This caused fears of a shortage of skilled workers. Therefore the Defence Department's wage top-up worked both to help soldiers and to induce them to learn skills when it may have been more attractive to abandon half finished apprenticeships and move straight into unskilled labour. University students who had left their studies unfinished were also assisted; a report to the Government from the District Repatriation Officer of Dunedin stated that many university students had approached the department for financial assistance to complete their courses, and the department had funded those who were continuing studies until the end of the year, when their cases would be reconsidered. ${ }^{24}$ Returnees were also given a textbook grant of $£ 55 \mathrm{~s} .{ }^{25}$ In 1919, 188 men had taken this up, but what is noticeable is that the department emphasised that these men were 'being assisted to learn professions - divinity, medical, law, accountancy, teaching, \&c. ${ }^{26}$ It is likely that the department dictated which degree courses men could undertake and would not fund those that were not vocational. Interestingly, the department would also fund those who wished to learn a trade and had not been in the process of doing

\footnotetext{
${ }^{21}$ Report from Defence Department in AJHR, 1919, H-30, p.6.

${ }^{22}$ Report from Department of Labour, in AJHR, 1920, H-11, p.2.

${ }^{23}$ Department of Labour, AJHR, 1920, H-11, p.2.

${ }^{24}$ Report from Repatriation Department in AJHR, 1919, H-30, p.14.

${ }^{25}$ Repatriation Department, AJHR, 1919, H-30, p.4.

${ }^{26}$ Repatriation Department, AJHR, 1919, H-30, p.4.
} 
so before the war, and provided vocational and technical training to some degree for these men. ${ }^{27}$ It was, however, more hesitant to pay the fees of those who were starting university on return, with the report from Dunedin stating that those in this position had to 'prove his ability before obtaining assistance...they should first of all expend their own money...when their funds are exhausted, providing their progress warrants it, this board will be quite prepared to see them through the balance of their time' ${ }^{28}$ For those men who did not have sufficient money to start university, this could mean moving straight into training in a trade, or unskilled work. Some men undoubtedly put off or abandoned their intentions to study at university due to lack of funds.

Despite government assistance and programmes returned men found themselves unemployed for a variety of reasons. Many soldiers anticipated returning to their former jobs on return, only to find that their place had been taken by a woman employed at a cheaper rate, or by civilians. Tensions flared when returnees found they were unable to return to these jobs. For example, an article in NZ Truth tells the story of a returned man who was a clerk before the war, who was complaining that 'Girls at a lower pay' had soldier jobs and that business owners were employing cheap labour for increased profits. He stated that "good" jobs available for returned soldiers' were 'laborious work that only men in the best physical health can hope to succeed in. ${ }^{29}$ Complaints were also made over civilians getting jobs that returned men had applied for. A letter written into NZ Truth complained that a Town Hall clerk position had been given to a civilian, despite three returned men applying, because 'the soldiers did not

\footnotetext{
${ }^{27}$ Repatriation Department, AJHR, 1919, H-30, pp.2-4.

${ }^{28}$ Repatriation Department, AJHR, 1919, H-30, p.14.

${ }^{29}$ NZT, 30 August 1919, p.1.
} 
have on white collars and everything spic and span' $^{\prime 30}$ In this case the writer complained that

for the short time our mayor will be in office he might have given the diggers a chance. Of course he was only too eager to send them to fight for him, but when it comes to giving them a job - oh no, that will never do. ${ }^{31}$

This sense of betrayal on return - that those who had sent them to fight had not kept promises on their return - permeates many writings and articles about returned soldier unemployment. An article in the Quick March detailing discussions at the annual RSA conference reported complaints made over 'lady clerks' being employed 'while returned soldiers are waiting to do clerical work' ${ }^{32}$ Culprits included local bodies and banks, along with the Hospital Board. Those at the meeting stated that 'Local bodies and the Government should be an example to private employers', echoing the sentiment of the returned man who wrote into NZ Truth. ${ }^{33}$ It was explained that the banks who were employing lady clerks had promised that they would be 'displaced when returned soldiers were ready to take their places' ${ }^{34}$ It appears that this promise was not being kept; and the visibility of these broken promises, particularly among government and local bodies who had made promises and plans before the war's end to employ returned men, angered returned soldiers and their advocates. Many returned men felt betrayed as jobs were not opened up for them. The anxiety of joblessness, along with the shame of not being able to provide for a family, is reflected in the anger they expressed at being replaced by women. Given that these women had

\footnotetext{
${ }^{30}$ NZT, 30 July 1921, p.9.

${ }^{31} N Z T, 30$ July 1921, p.9.

${ }^{32}$ QM, 10 June, 1919, p.56.

${ }^{33} Q M, 10$ June, 1919, p.56.

${ }^{34} Q M, 10$ June, 1919, p.56.
} 
moved in as a 'replacement' workforce it was considered quite reasonable that they would vacate these positions once men returned.

Negative attitudes towards women working came across in the press due to the demand for employment and the fact that women who had taken men's places during the war were still in their jobs. Undoubtedly many women enjoyed the freedom of working life, while others may have been reliant on the wages that they were now earning. Furthermore, the fact that women could be paid less to do the jobs that they had taken up was an incentive to keep them employed, as many returned men pointed out. This attitude is manifest in an article printed in Quick March on their new women's page. The writer was identified as a woman, who went only by the initials 'V.C.F.' ${ }^{35}$ V.C.F asserted that remaining in the workforce would lead to the deterioration of women's health, stating that 'the results on the race must become apparent in time' for those who had undertaken work during the war. ${ }^{36}$ V.C.F then stated that domestic work was one overlooked avenue of opportunity for women workers, and that it must not be looked down upon; she also pushed for domestic training for women as a qualification, and also suggested that childcare could become another avenue for women as they moved out of war work. Conservative, traditional roles were emphasised here yet the the writer was dismissive of 'lady wives' who did not learn domestic skills, stating 'It's time that the useless "lady" was wiped out of existence. There is no room in the world today for such a parasite' ${ }^{37}$ This reflected wider post-war concerns about young women. The article pushed for recognition of the value of the ability to do domestic work, which suggests that the writer felt that women were becoming dismissive of housework and homemaking skills and this is why

\footnotetext{
${ }^{35}$ QM, 10 June 1919, p.78.

${ }^{36} Q M, 10$ June 1919, p.78.

${ }^{37} Q M, 10$ June 1919, p.78.
} 
they still wanted to be in the workforce. The writer's argument that women could be earning money for doing domestic work quashed any complaints about single women needing to earn a living. This article gave a very conservative view, one that the RSA clearly found acceptable including a clear demarcation of gender roles. By portraying women's time in the workforce as potentially harmful to their health, the writer harnessed notions of women's duty to the nation as reproductive citizen-mother rather than war workers. The writer clearly felt that by moving women back into their correct role, men would then be able to take up theirs.

The RSA acknowledged its contradictory position on women workers. In stating that women who took up vacancies left by soldiers departing to war should now give up their positions, the RSA acknowledged that 'The committee has here departed from the general rule that repatriation at the cost of displacing others is not true repatriation, is unjust and economically unsound'. ${ }^{38}$ Their argument was that it 'had to be done because soldiers out of work in large numbers were a menace to the community'. ${ }^{39}$ Fears of soldier unrest and increased crime rates was used as a motivator to get returned men back into work. Interestingly, the RSA did not use arguments stating that women were selfish by holding on to their positions; furthermore, they did not bring up the 'breadwinner' role of men as a reason that men must have these jobs. Their anger was aimed largely towards employers and the government for continuing to employ women, for not terminating women's contracts, and for breaking promises they made to men departing for war. Indeed the rhetoric of broken promises was used far more widely, placing the blame on employers themselves.

\footnotetext{
${ }^{38}$ QM, 10 July 1919, p.53.

${ }^{39}$ QM, 10 July 1919, p.57.
} 
Temporary employment was seen as one solution to the employment problem; however, it did nothing to quell the uncertainties of post-war life. The RSA brought their concerns about returned men missing out on jobs to women and the issue of temporary employment to the Government. Quick March details this, noting that Sir James Allen's view of temporary employment for men was 'strongly unfavourable', pointing out that it was not a proper solution to the unemployment problem, as these men might lose their jobs later on. ${ }^{40}$ Allen was also spoken to about the importance of employing disabled returned men in Government departments, even if it was only temporary, as it would enable them to earn while looking for other jobs. ${ }^{41}$ It was argued that men should be able to take up temporary work, which at that point was being occupied by women workers who presumably were more willing to work these jobs which had little in the way of security. While Allen had a point in stating that giving returned men temporary jobs was not going to solve the overall problem of soldier unemployment (with which the RSA agreed), there was still merit in giving men these jobs as it allowed them to use their skills in the interim. Allen took action immediately to appease the RSA, by making many of the jobs that were being taken by these groups available; it was noted that 'a considerable number of the women clerks in the post office are being discharged' and the policy on temporary clerks was changed. Those who had not seen active service and were working for the military police were demobilised. ${ }^{42}$ Allen's actions here did open up some jobs for returned men, but as he stated, he did not create a long term solution for returned soldiers. However, this attempt at making some changes did lead to some returned men finding some kind of employment. Temporary employment functioned only as a stopgap

\footnotetext{
${ }^{40} Q M, 10$ June 1919, p.74.

${ }^{41} Q M, 10$ June 1919, p.74

${ }^{42}$ QM, 10 June 1919, p.74
} 
measure for these men, and the insecurity of joblessness was not truly removed from these men's lives. Unless these men were able to use their time in temporary employment to find full time work, the end of their contracts spelt a return to the worries of unemployment. This instability meant that men could not claim to be financially stable enough to marry or start a family; no doubt this held some men back in their personal lives.

Regional repatriation committees were also mindful of the lack of security that temporary employment gave. While the committees were proud of their success in employing many returned men, there was an acknowledgement that this work was often temporary and that this could not be considered a solution to unemployment issues. In the report to the government from the Repatriation Department, the Wellington officer stated that although men were being placed in jobs, they were often a step down from pre-war employment or purely temporary. ${ }^{43}$ He also stated that the Department did not consider its work done in this sense. Departments in other centres measured success in how many men were placed in employment, and either did not note that in many cases these jobs were temporary or downplayed the issues surrounding this. ${ }^{44}$ The stress that a soldier in a temporary job may have felt is not to be ignored; while he was indeed fortunate to be earning a wage, the uncertain nature of the work, including the prospect of unemployment that still loomed large in the future, would have been unsettling. Temporary employment merely alleviated the immediate issue, without providing long term solutions. In its favour, it gave men the opportunity to learn or use skills, and may have led to more permanent opportunities. However, those who were engaged in temporary jobs or jobs in which they were not

\footnotetext{
${ }^{43}$ Repatriation Department, AJHR, 1919, H-30, p.11.

${ }^{44}$ Repatriation Department, AJHR, 1919, H-30, pp.10-14
} 
being paid anything near their previous wage may have taken to the Situations Wanted columns as will be discussed below, or undertaken other forms of job hunting in search of something more permanent which would give them the sense of security that was so badly craved in post-war years. Being able to provide a breadwinner's wage, support one's family, or to settle down, were all important goals for a number of returned men at this time. Furthermore the desire to return to a more normal way of life is tangible in these men's desire to secure permanent employment, rather than following a drifter lifestyle.

Foreigners were also targeted as potential threats to returned men seeking jobs, with returnees feeling the Government was neglecting the needs of returned soldiers by allowing immigration to continue. A small article in NZ Truth in 1922 stated that the Wellington RSA had sent a deputation to the Wellington City Council Finance Committee on behalf of 'distressed "Diggers". 45 The men were requesting that Chinese immigration be checked and that Chinese who had settled in the Dominion be repatriated. Soldiers argued that 'While they were in competition with the Chinese, "Diggers" found it impossible to earn a livelihood'. ${ }^{46}$ Fears about Chinese immigration and its effects on the job market were prevalent around this time; a letter written into NZ Truth a month later named 'The Yellow Peril' blamed New Zealanders for encouraging the Chinese work force by patronising Chinese fruit and vegetable sellers. ${ }^{47}$ Again, the visibility of these workers setting up shops and working in the gardening trade upset returned men who were struggling for jobs; while the Chinese may have been setting up business independently, returned men saw them as a threat to their own business and also to jobs where immigrants would be favoured due to the

\footnotetext{
${ }^{45}$ NZT, 18 March 1922, p.1.

${ }^{46}$ NZT, 18 March 1922, p.1.

${ }^{47}$ NZT, 22 April 1922, p.3.
} 
ability to pay them lower wages. While it is unlikely that Chinese immigrants were taking many jobs from returned men - particularly skilled jobs where language skills would be required, such as clerical positions - they may have been taking the unskilled labour jobs on which some returned men relied on for their livelihood. In this case, any threat to their ability to get a job was seen as something that the government should work to prevent; particularly in light of the promises made by the government when men went to war. The RSA sent a deputation to the Government in 1919 and spoke to those in power about immigration. There was a call to 'put a stop to the influx of Asiatics, whose unfair competition was lowering the standard of living' ${ }^{48}$ The RSA argued that soldiers needed to be properly repatriated before the Government focussed on immigration, showing the Government that they felt soldiers were a priority over other groups at this time. Throughout all of these communications, there was clearly a strong belief that the Government, by allowing immigration to continue at the pace that it was, was putting returned soldiers' needs below its own economic priorities.

Feelings over immigration and its effects on returned men boiled over in April 1920 in Timaru with a group of men attacking three shops owned by Chinese fruiterers. The group tipped the fruit and vegetables on the ground, threw fruit at the windows, smashing them, and assaulted one of the shop's owners. ${ }^{49}$ It was stated that their actions were intended as 'a protest against the authorities allowing Chinese to compete in business with returned soldiers, and other white people'. ${ }^{50}$ More specifically, one person was quoted stating that

\footnotetext{
${ }^{48}$ QM, 1 December 1919, p.89.

${ }^{49} Q M, 10$ May 1920, p.67.

${ }^{50}$ QM, 10 May 1920, p.67.
} 
The disturbance arose through the Chinese opening up almost alongside of a returned soldier fruiterer, and...it is almost certain that the returned soldier will have to go out of business unless things improve. ${ }^{51}$

The article itself did little to condemn the actions of those who protested, instead focussing on denying the RSA had a hand in organising the riot as it was not seen as an effective means of working through the problem, and noting that three returned men who were looking on had stated that it would be more effective if women were told not to shop at the Chinese owned outlets and that names of women who did patronise the shops should be published in the local papers. ${ }^{52}$ Despite any views presented in the article, what is clear is that feelings were running high over the issue of Asian immigration and over the competition that Asian business owners presented to others. This increasing competition was immediately seen as a threat to the prosperity of New Zealand traders, whose right to trade was seen as more legitimate. This competition was directly affecting the returned soldier trader, therefore those who rioted saw fit to try to aid him by attacking the premises of the Chinese traders. It can also be argued that the actions of these men were indicative of a more general anger towards Asian immigrants, and the government for not taking action against those they felt were taking their jobs.

Those men who had returned from war and could not find work soon took to the 'Situations Wanted' columns of the newspapers, despite promises of help from the Defence Department to place them in jobs. In 1919, the Repatriation Department noted that only a quarter of returnees had sought their help to find work, and

\footnotetext{
${ }^{51} Q M, 10$ May 1920, p.67.

${ }^{52}$ QM, 10 May 1920, p.67.
} 
characterised this as the soldiers' 'spirit of self-reliance'. ${ }^{53}$ Whether men who advertised seeking work were those who had decided to take the situation into their own hands, or those who had already asked for help is unknown. What is interesting about these advertisements is the openness of the men about their status in life. While it is likely that returned soldiers advertised in these columns without stating that they were returnees, there are many advertisements in the Evening Post that state that the employment-seeker is a returned soldier. This both gave a reason for the man's unemployment - some would say a legitimate excuse - and also could have had the effect of invoking sympathy securing him employment above others. The Evening Post ran these advertisements throughout the 1920s. The advertisements were most popular in the immediate post-war years, with use of the columns peaking between 1920 and $1922 .^{54}$ What can be seen in the Evening Post's advertisements is the desperation of some men to obtain work; also, the various details that men use to attract potential employers are of interest. Firstly, the need for work came across in a soldier's willingness to accept low wages. Returned men included in their advertisements statements such as 'wages no object', 'willing to take any work for bed, tucker' 'small salary', 'small salary to start', and 'willing to take $£ 3$ a week' ${ }^{55}$ Contractors looking for work also advertised their reasonable prices and their willingness to take on the smallest of jobs. For example, one carpenter advertised 'Thoroughly capable Carpenter (Returned Soldier) requires Work; nothing too small. ${ }^{56}$ An Electrician advertised 'soldier holding electrician's license, Electrical Work of any

\footnotetext{
${ }^{53}$ Repatriation Department, AJHR, 1919, H-30, p.2.

${ }^{54}$ When looking at search hits for Situations Wanted columns in the Evening Post in Papers Past, 1920 had 67 hits, 1921, 77, and 1922, 56. Evening Post available online at http://paperspast.natlib.govt.nz/cgi-bin/paperspast.

${ }_{55}$ EP, 27 January 1923, p.1, 13 August 1921, p.1, 11 November 1921, p.1, 7 October 1920, p.3, 27 April 1922, p.1.

${ }^{56}$ EP, 27 April 1922, p.1.
} 
kind; houses wired at lowest possible rates' ${ }^{57}$ Returned men also showed they would take up any kind of work for wages. Some examples of this include 'Wanted, by a married Man, Work of any kind; Returned Soldier', and 'Urgent, married ex-Service man, good worker, seeks Situation, any capacity. ${ }^{58}$ Another man advertised wanting 'Work of any description; willing, references', and even broader advertisements included 'Young Returned Soldier desires Position in any Pacific Isle' and 'Married returned soldier wants work badly, do anything, go anywhere'. ${ }^{59}$ Another advertisement was more specific, but also contained the same pleading words 'Returned soldier, married, in desperate circumstances, wants Clerical or Light Work' ${ }^{60}$ All of these examples show that some returnees were struggling to find work, and that many were willing to take up temporary or unsuitable work simply to survive and provide for families. Their desperation is reflected in the flexibility of their terms; especially for those who stated that they would move anywhere and do anything. The fact that men included their marital status in these advertisements shows that they hoped this would help their cause.

What must be considered when browsing these advertisements and seeing the conditions under which men would work in is the effect on their families if they were breadwinners. The advertisement of the married man who stated that he would 'do anything, go anywhere' suggests that he would move away from his wife and any children for work or that his wife would accompany him. Men in this situation faced upheaval not only in their own lives, but also in the lives of their families. Separation from loved ones, or the upheaval of having to move away from familiar surroundings

\footnotetext{
${ }^{57} E P, 13$ February 1923, p.1.

${ }^{58}$ EP, 28 February, 1922, p.1, \& 14 March 1922, p.1.

${ }^{59} E P, 13$ January 1921, p.1, 18 August 1920, \& 27 April 1922, p.1.

${ }^{60} E P, 27$ April 1922, p.1.
} 
undoubtedly placed stress on relationships. For a soldier or his family having to move away, removal of support systems such as family who lived nearby or friends compounded this situation. Furthermore, they also faced the stress of low wages or undertaking work that was unsuitable for them in the long term. This included the frustration of having to put life on hold while making arrangements for temporary work, and the disappointment of not being able to return to pre-war jobs or to find a good stable job.

Many soldiers had great difficulty finding and retaining work on their return from the war. Women workers, who were paid cheaper wages, and a lack of government initiative in some areas appear to have been great contributors to this issue. However, the sudden influx of men returning - not all of whom could return to pre-war jobs - and a new generation of men now competing for jobs also contributed. The median age for enlistment was 24.3 years, with the mean enlistment age at around $20 .^{61}$ Therefore a large number of returning men would have been entering the workforce for the first time, or seeking training. For those who were older, becoming financially stable enough to start a family, or support family they already had were priorities. The lack of training that many men had was another issue that hampered efforts to find jobs. Many had been away from New Zealand during the years that they would have trained for a profession; for some of these men, settling down to studies and having to wait to earn a wage or to settle down in life would have been difficult. It also appears that employers believed that they could save more money by employing women. All of these factors led to men struggling to move forward with their post-war lives. Feelings over unemployment were running high; soldiers' anger was often

\footnotetext{
${ }^{61}$ Evan Roberts, Heights and Weights Database, Victoria University, 2010. This database records the details of 7,500 members of the NZEF including their age at enlistment.
} 
directed at the Government, which was seen to be not doing enough. Other groups, such as women, men who did not go to war, and Asian immigrants were all identified as threats to returned men's chances of getting jobs. This drew various responses from men and led to media and Quick March publications on these issues, often venting this anger and also making suggestions about what could be done to change these circumstances. In 1929, the Government heeded these calls for help, and the ExSoldiers Rehabilitation Commission was established. It was estimated that among those who had enlisted young and returned prior to establishing an occupation, and older veterans whose health was impaired (both pensioned and non pensioned), 5000 men were still struggling to find or hold down employment. ${ }^{62}$ Despite this, and despite a recommendation that these men be helped, the Soldiers Civil Re-establishment League formed after this enquiry focussed their efforts on disabled veterans only, with fit, unemployed veterans being left to seek help from their local RSA. ${ }^{63}$ This disappointing result left this group of veterans to struggle into the 1930 s.

For many men who were struggling to find employment, the Soldier Settlement scheme seemed like an answer to their problems. It would not only provide a source of income, but also gave men a chance to live on their own piece of land and to live out a more peaceful, idyllic and less stressful lifestyle. Moving away from city life and the urge for change were some of the reasons that men decided to undertake such programmes. The fact that men were wishing to settle down in many cases also led to the popularity of this programme.

The solider settlement program for returned WWI soldiers was an initiative that was undertaken in several countries including New Zealand, Australia and Canada.

\footnotetext{
62 Parsons, "The Many Derelicts of the War'?', p.105.

${ }^{63}$ Parsons, "The Many Derelicts of the War'?', pp.106-7.
} 
For returned soldiers, the settlements were an opportunity to take ownership of a piece of land, and live out the pastoral ideal. Arguably, a yeoman ideal lay behind such schemes, with governments dreaming of a 'large class of small producers' ${ }^{64}$ To soldiers, the appeal was to become self sufficient, freed from being a wage earner and able to live in the country. ${ }^{65}$ For many men such plans would have included bringing a wife and children onto the land. For returned men who could not find employment in the cities, or who were craving a change of pace, the promises of the settlement programme seemed attractive. To add to this, the economy was supporting the farming industry well in 1919, which was when much interest was shown in the settlement scheme. Promises of good returns and the assumption that the land sold to men would be of good quality led to many anticipating that they could pay back their loans with relative ease. For many, this was not the case. The government's attitude to soldier farming, particularly the idea that most returned men would make good farmers, is interesting as it draws in ideas of manliness that stem from their martial identities. Marilyn Lake, when writing on soldier settlement in Australia, noted that politicians felt that soldiers' experience in 'roughing it' in the trenches would 'fit them to tackle land settlement and put up with inconvenience' ${ }^{66}$ Similarly in New Zealand, Michael Roche argues that

The heroic view of warfare that carried through in MPs' minds to 1916 saw the returned soldiers as physically hardened by their trials and triumphs, and ready to return to New Zealand as stronger men, keen to take on the task of farming. ${ }^{67}$

\footnotetext{
${ }^{64}$ Marilyn Lake, The Limits of Hope: Soldier Settlement in Victoria, Melbourne, 1987, p.25.

${ }^{65}$ Lake, Limits of Hope, p.136.

${ }^{66}$ Lake, Limits of Hope, p.40.

${ }^{67}$ Michael Roche, 'Empire, Duty and Land' in Lindsay Proudfood and Michael Roche (eds.) (Dis)Placing Empire - Renegotiating British Colonial Geographies, Hampshire, 2005, p.146.
} 
Soldiers were often seen as hardy and innovative; the perfect candidates for farming. Their lack of real skills in many cases, was overlooked due to this. Farm work was also a cure for unemployment and its hard work was seen as a tonic for any fears of men becoming 'shirkers'. ${ }^{68}$ By 1924, 10,552 men had taken up 9635 farms, showing the popularity of the programme. ${ }^{69}$

The success of the programme in New Zealand - and in other countries - is widely debated, and many New Zealand historians have denounced the soldier settlement system as a failure. ${ }^{70}$ This debate, while interesting, is not the main focus of my discussion. What can be argued is that many soldiers who acquired land under the programme underwent significant hardships, and some did, indeed, fail. This was due to many factors - the economy, which deflated land, crop, milk, and wool prices; possible over-valuation of properties that were purchased by the government; the unsuitability and subsequent deterioration of chosen plots of land; and inexperience on the soldiers' part. These are all reasons cited by soldiers, and the government, for the failure of some soldiers to make a success of their farms. The economic downturn in 1921, fuelled by a sudden drop in demand for exports to Britain of meat, wool and dairy products spelt disaster for many settlers. At this time, New Zealand was a largely agricultural nation that relied on Britain for income; therefore this loss of demand had serious consequences. ${ }^{71}$ Furthermore, intense land speculation, driven by the right of purchase given to farmers by a tenurial law change in 1913, continued throughout the war and drove the price of land up while many soldier settlers were taking up their

\footnotetext{
${ }^{68}$ Roche, 'Empire, Duty and Land', p.146.

${ }^{69}$ Ashley Gould, 'Proof of Gratitude? Soldier Land Settlement in New Zealand after World War I', PhD, Massey University, 1992, p.286.

${ }^{70}$ See for example, Nicholas Boyack and Jane Tolerton, In The Shadow of War, Auckland, 1990, p.247; Miles Fairburn, 'The Farmers Take Over (1912-1930), in Keith Sinclair (ed.), The Oxford Illustrated History of New Zealand, Auckland, 1990, p.205; W.H. Oliver, The Story of New Zealand, London, 1960, Keith Sinclair, A History of New Zealand, Reading, 1959.

${ }^{71}$ Brooking, 'Economic Transformation', p.232.
} 
settlements. ${ }^{72}$ It is estimated that half the rural land in New Zealand changed hands between 1916 and 1924, and land was massively over-valued. ${ }^{73}$ The recessions of the 1920s soon deflated these values and left farmers over-committed to large mortgages, and all too often, land that was rapidly deteriorating in quality.

Rather than debating success or failure, soldier settlement is treated in this thesis as an insight into a group of returned soldiers in a particular profession. No other occupation has so many files that relate purely to the employment of returned soldiers. The soldier settlement programme was documented by the government, and created specifically for returned soldiers, unlike other jobs. These files shed light on a group of returnees all undertaking the same profession, with mixed success. The files tell the stories of men who underwent various trials, and through these stories emerge the effects that these difficulties had on them and their families, and the various hardships that they had to experience. Because soldiers lived on the land that they worked, difficulties in living arrangements were more obvious to inspectors than in other occupations. The returnees' financial status was also laid bare in the government's records, simply due to soldiers taking out loans from the government for the farms. The plight of soldier farmers comes through much more often in the press than any other group of returnees struggling in various occupations. Soldier settlement proves to be an interesting and useful case study of employment for all of these reasons.

Farms were a heavy financial undertaking for returnees, some of whom had had little or no deposit available when applying for the farms and soon found themselves saddled with large loans. Loans ranged in the thousands of pounds. The

\footnotetext{
72 Brooking, 'Economic Transformation', p.236.

${ }^{73}$ Brooking, 'Economic Transformation', p.236.
} 
wage rate of two returned soldiers, Daniel James and William Dellow, were listed as ' $£ 3-10$ ', which would put a total yearly wage at around $£ 182 .{ }^{74}$ These were their prefarming jobs, so presumably there was a hope that a higher income would be earned from the farms. However, some farmers ran into problems early and often. Taking into consideration the time that it takes to set up a farm - fencing, clearing land, and acquiring stock - soldiers could not be expected to make large amounts of money from the farm straight away. However, mortgages still had to be paid, and this was where trouble began. Some soldiers were often unable to make payments on the loan, and had to apply for it to be postponed until they had the money to pay it off. Once this cycle started, it was often hard to climb out of the mounting debt. This, along with advances on the soldiers' current accounts for improvements to the farm, and interest due on this account, led to further indebtedness. If a soldier had a bad year for crops, or similar bad fortune, this could spell near disaster. In the midst of these complications, many of the men, who were single when they came onto the farms, got married and had children. The stress of having extra dependants would have undoubtedly taken its toll on the men and their families. Wives, while being able to help on the farm when they were childless, would be occupied by childrearing and housekeeping in most cases. This meant that the men were largely on their own in providing for their families. Any extra help that they hired had to be paid out of their own wages, so the benefits of this are balanced accordingly.

Predictions about the soldier settlement scheme's potential difficulties arose in 1918 in an article in NZ Truth, which questioned the Government's purchase of part of the Clifton Estate in Otago for returned soldier farms. The article criticised the

\footnotetext{
${ }^{74}$ Memorandum to the Commissioner of Crown Lands, April 18 1920, Discharged Soldiers Settlement Daniel James and William John Dellow, 1920-1922, AAMB RLDSS 24/1, Archives New Zealand, Wellington.
} 
purchase, stating that 'the Government purchased the worst portion of the Clifton Estate, and soldier-settlers on the sand portion would need to be expert farmers and slogging workers to even make a living out of it. ${ }^{, 75}$ The article expressed doubts that returned men who took on the land would be able to cope with it, simply because they did not have farming experience of the kind that would be required to be successful with this land. They were also critical of the government's overall choices in land purchases. The article's message was that 'we may expect to hear that very few of the returned men who settle on the Government's "gifts" will blossom forth as ordinary farmers. ${ }^{76}$ Concerns about land quality were also shared in the Quick March in May 1919. Under the header 'Pumice for Diggers' a letter to the editor stated that the writer had visited and inspected some of the plots of land that the government had bought in the Rotorua area and found that they were difficult for farming (though not impossible), and it was 'questionable whether it can ever be brought to a high state of productivity'. ${ }^{77}$ In this case, the writer was incensed that farmers had sold this land to the government in the first place, complaining about the 'sort of men we have been fighting for', and naming them as 'Profiteers of the most virulent type'. ${ }^{78} \mathrm{He}$ was also against the government, stating that the land was proof of 'their miserable efforts in this branch of repatriation'. ${ }^{79}$

Water, the lack of it, and insufficient minerals could all lead to misery for soldier farmers. Another article in July 1919 stated that a group of soldiers near Cambridge had been 'placed on sour peat bog. In winter the land was practically a sponge, oozing water at every touch; in summer it became a tough fibrous mass,

\footnotetext{
${ }^{75}$ NZT, 29 June 1918, p.6.

${ }^{76}$ NZT, 29 June 1918, p.6.

${ }^{77}$ QM, 10 May 1919, p.32.

${ }^{78}$ QM, 10 May 1919, p.32.

${ }^{79}$ QM, 10 May 1919, p.32.
} 
defying all efforts to work it'. ${ }^{80}$ Later, in 1923, a NZ Truth article told the story of farmers on the Hauraki Plains who were struggling with 'moisture-laden land'; their attempts to dig drains into it were proving unsuccessful. ${ }^{81}$ Some soldiers had attempted to put stock on the peat, but this packed it down, making it unusable. There were fears that the land would turn into 'vast lagoons in a few years time unless an extensive scheme of stop-banking is undertaken'.82 Near Ashburton, settlements suffered from drainage issues, phosphate deficiency, and erosion. ${ }^{83}$ Ashley Gould argues that many pasture problems were caused by grazing on pastures before soldiers purchased them. ${ }^{84}$ Yet it appears that there were fundamental issues with the land to be farmed along with the land being already worked before soldiers went onto it. Land quality was not the only issue that was named when it came to the failure of settlements. Land that was bought by the government was often subdivided in an effort to provide more sections. This practise led to large, productive tracts of land becoming useless to men due to the land not being suitable for closer settlement. ${ }^{85}$ Problems with the land that was purchased varied; but all of them led to the inability to work the land and mounting debt. Many of the farmers were simply not equipped to deal with the problems that the land presented to them. They were fully reliant on the cash advances that the government provided, particularly if their farm was not productive, and these could be limited or refused if the soldier already owed a lot of money - which was often the case for those who were on troubled farms. Many farmers lacked the expertise needed to make these farms work - while placed in extremely difficult conditions, more experienced men may have known how to work

\footnotetext{
${ }^{80}$ QM, 10 July 1919, p.42.

${ }^{81}$ NZT, 10 November 1923, p.6.

${ }^{82}$ NZT, 10 November 1923, p.6.

${ }^{83}$ Parsons, "The Many Derelicts of the War'?', pp.170-1.

${ }^{84}$ Gould, 'Proof of Gratitude?', p.188.

${ }^{85}$ QM, 10 August, 1922, p.31.
} 
more difficult and less fertile land, particularly in terms of what should be sown on such land and how to fertilise and drain it. However, in many cases the quality of the land was such that it would need to be completely overhauled before being used for farming - something which none of the farmers, or the government, would have anticipated. This unanticipated hardship was undoubtedly stressful and very disappointing for these men.

Soldier farmers' inexperience was an issue that was tackled by the media and the RSA. The government seemed to have few standards by which to measure soldier settlers against. The NZ Truth pointed this out noting that 'the Government considered every man with a satisfactory military discharge a fit and proper person to become a farmer' ${ }^{86}$ This sentiment was echoed in 1929, with the NZ Truth stating in an article about the deteriorating, untenanted soldier farms around the country, 'In fulfilling its promise to provide holdings to returned men, the Government or the local land boards failed to look closely enough into the qualifications of some would-be farmers' ${ }^{87}$ Indeed, advertisements for soldier farms in Quick March state that 'Any discharged soldiers may obtain option over a block of private land, and, if the proposition is a satisfactory one, the land will be purchased by the crown' ${ }^{88}$ Later in the NZ Truth article it is noted that the New South Wales scheme has worked out similarly; the sentiment being

Men without any knowledge of land settlement, without any experience of country life or conditions, broken in health, and without any aptitude for such a calling, were placed on areas of land, with a debt of thousands of pounds hanging over them. ${ }^{89}$

\footnotetext{
${ }^{86} N Z T, 18$ August 1923, p.7.

${ }^{87}$ NZT, 17 Jan 1929, p.4.

${ }^{88}$ QM, 10 May 1919, p.69.

${ }^{89}$ NZT, $18^{\text {th }}$ August 1923, p.7.
} 
Ashley Gould also argues that 'Participation in combat, and later simply service in the army, seemed sufficient to establish the soldiers' pedigree to be settler and farmers' ${ }^{90}$ Part of this, he argues, is the general feeling that soldiers would return as 'better citizens' and that they would be a 'tremendous force for change in the dominion'. ${ }^{91} \mathrm{He}$ also noted that a sense of soldiers embodying ideals and hopes for the future has been identified. ${ }^{92}$ Clearly patriotic sentiment and a misunderstanding of the nature of war and its effects on soldiers fuelled such fantasies. What is clear is that the government's plan to help these men reintegrate led them to exempt these men from being suitably qualified to farm, and they obviously believed some skills or innate ability to farm had been instilled in these men due to their war service. Much like the exemptions made for men wanting to work in other professions, such as in the railways or as clerks, they were designed to make life easier for returnees, and in turn, reduce the government's responsibility for them by placing them in gainful employment. They also showed a great faith that these men were entirely capable of these jobs despite their lack of experience.

Financial pressure and social pressure around breadwinning could be disastrous for returnees. Daniel Hurley's farming experiences led to illness, injury and a mental breakdown, all of which affected his ability to farm. He applied for a farm in Moutere, Motueka in 1920, stating twelve months farming experience on his application. ${ }^{93}$ Hurley began to grow hops, but by January 1922 was unable to make a mortgage payment and had to apply for a postponement until his hop crop was harvested and

\footnotetext{
${ }^{90}$ Gould, 'Proof of Gratitude?', p.47.

${ }^{91}$ Gould, 'Proof of Gratitude?', p.53.

92 Gould, 'Proof of Gratitude?', p.52.

${ }^{93}$ Application for an Advance under Section 2 of the Discharged Soldiers Settlement Amendment Act, 1917, 9 August 1920, Discharged Soldiers Settlement - Daniel Hurley, AAMB RLDSS 10/1, Archives New Zealand, Wellington.
} 
sold. ${ }^{94}$ In his application, Hurley stated that the farm probably would not turn a profit until the end of the next year, due to his hop crop failing and the slower growth of his fruit crops. ${ }^{95}$ Despite this, his application failed and Hurley was ordered to pay the amount of $£ 82-11-4$ by 11 June 1922 . The following years brought many hardships for Hurley; he made applications for postponement, some of which were approved, his land was devalued and rated as 'cold, heavy, second class land' and his hops a 'precarious crop'. ${ }^{96}$ Hurley's debts grew, but he was aided by his father in law, a director at the firm who sold his hops on behalf of him, who allowed Hurley's advances

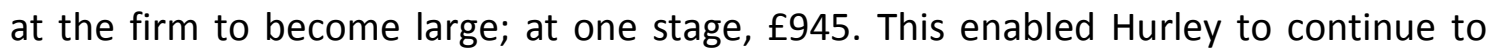
work on his crops. However Hurley's crops were suffering by 1926, with one garden infected with brown rot. They were also growing badly due to soil deficiency; Hurley needed lime to help their growth, and this was a considerable expense, along with manure. ${ }^{97}$ Another blow was dealt in 1927 , with Hurley having an accident which left him incapacitated and unable to work on the farm for around three months. ${ }^{98}$ In 1929 Hurley wrote to the Commissioner of Crown Lands to state that he had to abandon another $1 \frac{1}{2}$ acres of hops. He also stated that his tobacco crop had failed, and this had cost him $£ 444$ total from the loss of crops and his now useless tobacco kiln. ${ }^{99}$ His herd of cows was growing, but was not yet profitable, and Hurley was asking for a remission

\footnotetext{
${ }^{94}$ Letter to The Commissioner of Crown Lands, 27 January 1922, Discharged Soldiers Settlement - Daniel Hurley, AAMB RLDSS 10/1, Archives New Zealand, Wellington.

${ }^{95}$ Statutory Declaration, 25 January 1922, Daniel Hurley, AAMB W3099 65 RLDSS 10/1. Archives New Zealand, Wellington.

${ }^{96}$ Statutory Declaration, 22 May 1923, Discharged Soldiers Settlement - Daniel Hurley, AAMB RLDSS 10/1, Archives New Zealand, Wellington.

${ }^{97}$ Correspondence to the Chairman of Dominion Revaluation Board from Commissioner of Crown Lands, 17 December 1926, Discharged Soldiers Settlement - Daniel Hurley, AAMB RLDSS 10/1, Archives New Zealand, Wellington.

${ }^{98}$ Correspondence to Commissioner of Crown Lands from Buxton and Co. Ltd., 29 March, 1927, Discharged Soldiers Settlement - Daniel Hurley, AAMB RLDSS 10/1, Archives New Zealand, Wellington.

${ }^{99}$ Correspondence to Commissioner of Crown Lands from Daniel Hurley, 22 October 1929, Discharged Soldiers Settlement - Daniel Hurley, AAMB RLDSS 10/1, Archives New Zealand, Wellington.
} 
of rent in the meantime while waiting to make some money. ${ }^{100}$ By this stage Hurley's debts were considerable; his efforts to make a profit from the farm had stretched over ten years, and he was struggling to make money from his crops despite many attempts. This was no doubt wearying; Hurley's constant struggle to break even would have been immensely stressful, particularly in terms of his own living conditions. Hurley's post war experience had been a protracted struggle to make a living. His repeated applications for postponement and financial help and consideration show his desperation and the amount of financial stress that he was labouring under.

Finally, Hurley became mentally unstable, and was described as being 'violent in his attitude towards his wife' and for that reason he was made to leave the farm while his wife stayed to carry on. ${ }^{101}$ This was blamed on both his 'war services and one or two serious accidents since his return to New Zealand (head injuries)., ${ }^{102}$ Despite the rift in their marriage, Hurley was amenable to his wife taking over the securities of the farm, and it was stated that she had been doing 'practically all the work on the section' in correspondence about this - it is unclear how truthful this really is. ${ }^{103}$ Hurley's injuries clearly set him back, so she may have had to do the majority of work. Hurley had 'gone out rabbitting in the hope that a change of occupation might be of some benefit to him. ${ }^{104}$ The Commissioner of Crown Lands expressed doubt at this,

\footnotetext{
${ }^{100}$ Correspondence to Commissioner of Crown Lands from Daniel Hurley, 22 October 1929, AAMB RLDSS 10/1, Archives New Zealand, Wellington.

${ }^{101}$ Memorandum for Undersecretary of Lands, 13 June 1930, Discharged Soldiers Settlement - Daniel Hurley, AAMB RLDSS 10/1, Archives New Zealand, Wellington.

${ }^{102}$ Memorandum for Undersecretary of Lands, 13 June 1930, AAMB RLDSS 10/1, Archives New Zealand, Wellington.

${ }^{103}$ Memorandum for Undersecretary of Lands, 13 June 1930, AAMB RLDSS 10/1, Archives New Zealand, Wellington.

${ }^{104}$ Memorandum for Undersecretary of Lands, 13 June 1930, AAMB RLDSS 10/1, Archives New Zealand, Wellington.
} 
stating that 'he is not likely to improve but will gradually become worse'. ${ }^{105}$ Why the Commissioner was of this opinion is unclear; perhaps he felt that Hurley's war experience and injuries had indelibly marked him, and led to his illness. If this is the case, it further demonstrates that the Commissioner did not feel that the stress of working the farm had caused Hurley's violence. Yet a break from the stress of trying to work the farm for a living would have released much of the pressure on Hurley. It appears that after the farm was transferred to his wife at the value of $£ 1000$, Hurley was living with his wife again. ${ }^{106}$ While one can only speculate as to the nature of this arrangement, this shows that Hurley managed to reconcile with his wife to some degree.

Hurley's mental illness appeared to have many possible causes, some of which were discussed in his file. The Commissioner felt that his war service and subsequent head injuries, which he possibly sustained while farming were to blame for his violence. However, Hurley's statement that a change of occupation would do him good suggests that Hurley felt he was being negatively affected by the stress of farming. This was not uncommon; in Australia, soldier settlers' wives and children described the 'unpleasant domestic scene' that could eventuate from 'frequent outbursts of temper', brought on by the stress of trying to make a living off their farms. ${ }^{107}$ For Hurley, the dream of being able to support his family had fallen apart. A number of factors had caused him to become mentally ill, and he had to give up his farm because of it. He also became separated from his wife and two children. In this case, his wife took over the farm, which meant that she and her children could remain living there and she

\footnotetext{
${ }^{105}$ Memorandum for Undersecretary of Lands, 13 June 1930, AAMB RLDSS 10/1, Archives New Zealand, Wellington.

${ }^{106}$ Memorandum to Commissioner of Crown Lands, 1 June 1931, Discharged Soldiers Settlement Daniel Hurley, AAMB RLDSS 10/1, Archives New Zealand, Wellington.

${ }^{107}$ Lake, Limits of Hope, p.168.
} 
could try to make a living. However, this was far from the pastoral dream that many men had when walking on to the land. Furthermore, it had separated Hurley's family, caused trauma for his wife and children, and had financially drained him. The dreams and hopes for the post-war lives of soldiers, in some cases, turned to heartbreak, not only for the soldiers themselves, but for their families. Women who went into marriage hoping for a secure future could be disappointed by such circumstances, and faced hardships that they were likely unprepared for. They often had to help to work the land, which was draining work for those who were also raising children. For these men, and their families, the war was continuing to affect their lives, despite their return to peace.

Soldier settlement had its own specific problems such as the living conditions of these men and their families, which could be difficult and unpleasant on some farms due to a lack of dwellings or problems with these dwellings. Soldiers were allowed in some cases, if there was no dwelling provided on the land, to apply for an advance on their mortgage to build a house. Daniel James and William Dellow took advantage of this, drawing down $£ 250$ for a 'dwelling'. ${ }^{108}$ This, of course, was a sizeable addition to the mortgage, but necessary. This is in contrast to farmers in the Victoria soldier settlement, many of whom lived in tents or shacks with no means to improve the situation. ${ }^{109}$ However, living conditions could still prove to be difficult for some New Zealand settlers. Some men were unable to take out large amounts to build a dwelling, with one solider living in his cowshed until he could afford to build 'a small two roomed shack'; his farm was so isolated that the timber had cost $£ 10$ to buy and $£ 11$ to

\footnotetext{
${ }^{108}$ Statement of advance recommended, Commissioner of Crown Lands, 18 May, 1920, Discharged Soldiers Settlement - Daniel James and William John Dellow, 1920-1922, AAMB RLDSS 24/1, Archives New Zealand, Wellington.

${ }^{109}$ Lake, Limits of Hope, p.154.
} 
cart in. ${ }^{110}$ His financial situation did not improve, and he did not see a way that he could afford to build a home. ${ }^{111}$ The lack of the ability to build a place to live that was more than a shack would have been extremely discouraging to settlers. Another settler found that the inability to build a home affected his health, with the tents he was living in rotting and the 'damp...trying to his health' ${ }^{112}$ This inability also restricted settlers' ability to bring a wife or family onto the land. For those who did manage to build homes, the land was sometimes unkind. The NZ Truth reported that some soldier farms, which were located on former swamp lands, were suffering from sinking peat problems and that

on some sections innumerable stumps are now showing...whilst many buildings have settled down unevenly, and some have settled on the stumps, which came through the floors....Even on sections where there is still a good depth of peat, the tramping around the back doors of residences has caused consolidation, making the buildings lean backwards. ${ }^{113}$

The heartbreak that these sinking houses and buildings must have caused is considerable. For many of these men and their families, the house would have been something of a haven, a place where some warmth and rest could be taken. Even if they could not provide much comfort, for many soldiers having a house meant that they could have their wives and children in residence on the farm, which must have been of considerable importance both for personal reasons and for economical considerations - wives and older children could undertake some of the work on the farm. The prospect of homelessness or a return to rough living would have been immensely disappointing to those soldiers. The role of women in shaping the household cannot be overstated. Some soldiers did not bring their wives onto the land,

\footnotetext{
${ }^{110}$ NZT, 21 March 1925, p.1

${ }^{111}$ NZT, 21 March 1925, p.1

${ }^{112}$ Gould, 'Proof of Gratitude?', p.204.

${ }^{113}$ NZT, 19 July 1924, p.5.
} 
one example being Cyril Inwood, who had married and since then lived in a local township with his wife, despite there being a house on the section. ${ }^{114}$ Many of the wives of the settlers who lived on the farms would have struggled to make the dwellings that had been built on the land homely and comfortable; particularly due to financial constraints and the stress that they were under if they were also required to work on the farm. To have such efforts go to waste would have been very distressing. Pastoral dreams of families living together on farms and being able to build a home were in some cases ruined.

Isolation was another unpleasant element of the soldier settler's experiences, one which could make working a farm much more difficult. Many of the farms were in remote areas, some of which had very limited access. An NZ Truth article described the isolation in 1919, noting that 'away in the backblocks, without rail, and with little road communication, there are hundreds of thousands of acres of cheap pumice land...The fact that there are no railways is the reason of its cheapness' and pointed out that men could be 'banished to the wilds for a term exceeding anything like ten years' ${ }^{115}$ This sounds like an exaggeration, but in 1925 another NZ Truth article on the plight of soldiers living near Morrinsville encapsulated this. The town was only 20 miles away, but the writer describes how 'In winter time their isolation is complete, for the road is impassable by any sort of conveyance. One man has been off the settlement only once in five years and that merely for a couple of days in order to make a flying visit to Auckland. ${ }^{116}$ The dissatisfaction of these soldiers is shown in these articles. This shows that farms without proper access could become problematic when natural forces came

\footnotetext{
${ }^{114}$ Letter to Commissioner of Crown lands from A. Whitehorn, Crown Lands Ranger, 28 January 1924, in Discharged Soldiers Settlement - C H Inwood, AAMB RLDSS 27/1, Archives New Zealand, Wellington.

${ }^{115}$ NZT, 1 March 1919, p.1.

${ }^{116}$ NZT, 21 March 1925, p.1
} 
into play, with the men unable to leave. This could also cause problems for their productivity, with the winter weather meaning the settlers' access track was in such a bad condition that they 'could not even drive stock down it, and to ride a horse over was dangerous. When they wanted to get their cream away they had to pack it out. ${ }^{117}$ This was not only time consuming, but also had financial impact, with the writer explaining 'The difficulty of access and the consequent high cost of carting, has reduced the quantities of fertilisers which these men can put on their land, and the pastures...have consequently to suffer. ${ }^{118}$ For these men, their isolation was costing them money that they needed desperately to fertilise their land. This led into a cycle of lost productivity, with soldiers losing money whenever they tried to make it selling their goods. The effects of such isolation also meant that many soldiers would have found themselves restricted socially, with only the company of other settlers nearby; prospects for marriage and a family life could be much reduced in this situation. The stress of living on so little and trying to make their farms successful, coupled with a lack of social contact, would have made these men's lives quite lonely; if they were already feeling miserable over the state of their farms, their enforced solitude and the difficulties it created may have compounded this, making it seem all that more attractive to abandon their farms. Clearly their complaints in the media show they were dissatisfied with their position.

The government used the soldier settlement programme as employment for returnees. Yet in some cases the programme did not provide the stability that full time employment promises. Some soldiers had to seek other employment while on their farms, such as Cyril Inwood who went out working on the roads while still being in

\footnotetext{
${ }^{117}$ NZT, 21 March 1925, p.1

${ }^{118}$ NZT, 21 March 1925, p.1
} 
possession of his farm. His farm suffered from the neglect, but Inwood was clearly trying to make some money to live on, and perhaps to pay his mounting debts. ${ }^{119}$ By May 1924, Inwood had given up on his farm. ${ }^{120}$ For Inwood and the hundreds of other soldiers who walked off the land, his farm turned out to be a purely temporary form of employment which cost him financially. These men, once off their farms, had to find other work, therefore putting them back into the pool of men who were still trying to find employment. Settlement taught these men farming skills that may have helped them in future jobs, however some men found they disliked or could not cope physically with farming. For these men their foray into farming may have seemed a waste of time and money, or at the very least a disheartening experience. For those who kept their farms, the hard work and large amounts of money spent on these farms meant that poverty was still a real concern. These men were employed, but some struggled severe financial problems. Government concessions often prevented these men from defaulting on loans, but led them into huge debt. Therefore life for some soldier farmers, while busy and productive, was also strained by low or no income.

For returned men, the idea of owning their own piece of land and being able to farm this, along with live on it, was an exciting prospect. Gould notes that 'The horrors of the front line...may have made the prospect of farm life in New Zealand very appealing' ${ }^{121}$ The government made it easy for men to become farmers; it was a viable alternative to seeking employment in a difficult job market. However, the government's attempts to make this scheme accessible proved to be its downfall. Inexperienced men were placed on inferior land which was overvalued. The settlers

\footnotetext{
${ }^{119}$ Report to Commissioner of Crown Lands, 1 June 1922, in Discharged Soldiers Settlement - C H Inwood, AAMB RLDSS 27/1, Archives New Zealand, Wellington.

${ }^{120}$ Letter to the Commissioner of Crown Lands from C H Inwood, 10 May 1923, in Discharged Soldiers Settlement - C H Inwood, AAMB RLDSS 27/1, Archives New Zealand, Wellington.

${ }^{121}$ Gould, 'Proof of Gratitude?', p.47.
} 
were burdened with large mortgages which limited their ability to spend money on improving their farms, and many could not turn a profit on their farms while they were still establishing them. This led to spiralling debt. For some settlers, this combination led to them having to walk off their farms after years of difficulty; others stayed, but suffered poverty and in some cases, poor living conditions. Daniel Hurley found the stress of running his farm so severe that he became mentally unstable; undoubtedly there were other men who found the stress of their farms too much to cope with. The isolation that was often part of these men's lives could take a toll, and certainly would have impacted the dreams of those men wishing to marry and have families, but who could not leave their farms. The idea that returned men would make good farmers due to their ability to live rough was not altogether untrue. Many of settlers lived under extreme financial and mental stress, in poor conditions. Despite the difficulties, these men often struggled for years to make a profit on their farms, working hard against adversity. There is much to be said for the hardiness of many of these settlers and their determination against the odds. That it became too much for some to continue on with is unsurprising; to be under such stress after the horrors of war was an unfair turn of fate and was not anticipated by these men or by the government. The sad legacy of soldier settlement was that pastoral dreams were shattered for so many men who attempted farming in earnest.

In the wake of the lack of success of employment and soldier settlement initiatives by the government, a sense of betrayal pervaded both the media's representations of these issues and soldiers' writings and opinions. For these men, who had risked their lives for their country, the fact that they could not secure employment or were struggling on settlement farms after up to four years at war 
angered them. These men, in many cases, wanted their lives to return to normal. They wanted to resume their pre-war lives, or start again post-war. Their dreams and goals for their lives were all too often put on hold or thwarted due to the inability to get a job or to make a success of their farms - so many dreams relied on their ability to have a steady income. To get married and support a family, or to chase other dreams, or simply to maintain self-respect, these men needed jobs - and this was something that caused much stress. This resulted in men appealing to the government to help them by providing employment schemes and training, by making sure that they were no longer employing girl clerks in government departments, by putting a stop to immigration. Settlers urged the lands department to delay their mortgage repayments, and to provide them with more money so that they could work their land and make a profit. They also expressed anger at the quality of the land that they were on; this led to revaluation later in the 1920 s, which often slashed the original value of farms. For returned men affected by the employment crisis and the problems of soldier settlement, their dreams stayed as such; their desires to move on from the war and resume their lives were delayed or unfulfilled. This undoubtedly led to stress and pain for men who had already suffered at the hands of war. For some men, additional problems hampered their ability to gain employment. Alcoholism and soldiers' reputation as 'heavy drinkers' also disadvantaged men in the depressed job market of the 1920s. Alcoholism and alcohol consumption became a focus of anxiety around the 'returned soldier problem'. The next chapter addresses these issues. 


\title{
Chapter Three: Alcoholism
}

\author{
...it certainly was a fact that a lot of them did take to the booze. ${ }^{1}$ \\ - Frederick Dill, 1988.
}

One of the features of life at the front was the availability of alcohol, and its use as a relaxant and social lubricant. Yet what could be a relaxing activity at the front became a serious problem for some, and this manifested itself on return. Alcoholic returned soldiers' plight had a great effect on their families and created anxiety in society over drunken soldiers and the misdemeanours that could occur in such a state. Furthermore, the Defence Department would not take responsibility for these men, stating that their condition was not attributable to war service. Alcoholism amongst returned soldiers in New Zealand is an issue that has not been explored in any great depth in historical writings, yet through newspaper reports it is clear it was a feature of New Zealand's post war society. John Weaver and David Wright explore the issue briefly in their article 'Shell Shock and the Politics of Asylum Committal in New Zealand', noting that many alcoholic soldiers were deliberately classified as neurasthenics, seemingly in an effort to get the men some help. ${ }^{2}$ Weaver and Wright also note that the Director General Medical Services, Brigadier General Henderson, suggested doing so to avoid the soldiers being stigmatised. ${ }^{3}$ They also note the argument by a Defence Department committee looking at the problem of alcoholic returned soldiers in 1920 that suggested that '70 percent of them had also been heavy

\footnotetext{
${ }^{1}$ Frederick Dill, interview by Jane Tolerton and Nicholas Boyack, 29 September 1988, for the World War I Oral History Archive, held in the Oral History Centre, ATL, OHC-002612.

2 John Weaver and David Wright, 'Shell Shock and the Politics of Asylum Committal in New Zealand, 1916-22', Health and History, Vol.7, No.1, 2005, p.34.

${ }^{3}$ Weaver and Wright, 'Shell Shock', p.34.
} 
drinkers before the war', and that others were in disagreement with this. ${ }^{4}$ These observations all show the Defence Department's reluctance and lack of knowledge over how to deal with these men. The stories of returned soldier alcoholics are difficult to find and the effects on their families often hidden, with media reports one of the only sources that illuminates them. The lack of real treatment options, the government's lack of engagement with this problem, the stigma of alcoholism and the subjective nature of what is perceived as excess drinking all contribute to alcoholic returnees not being represented in the historical record. However their condition could become severely debilitating and tear families apart, causing financial and personal strife; it cannot be dismissed as unimportant. In this chapter I draw out some soldiers stories, and examine the effects that excessive alcohol consumption had on the lives of returned men and their families as they appeared in court reporting and the RSA newsletter. I will also scrutinise the stereotype of soldier drinking and the role of the RSA as a provider of alcohol, as well as its attempts to assist soldier alcoholics. The role of prohibitionists in promoting fears of soldier drinking will also be explored. This chapter will show government concerns and responses to the problem, the RSA's views, the media's portrayal of drunken men and public fears of returned soldier drunkards, and returned men's responses to questions asked about soldier drinking stereotypes. Through all of this I will argue that alcohol abuse created uncertainty in terms of health, the ability to provide for one's family, and family togetherness. The war continued to affect these sufferers and their families' lives.

In 1919, the Evening Post reported on the case of a returned soldier who was facing charges of ill-treating his children. The sensationalist headline stated 'An

\footnotetext{
${ }^{4}$ Weaver and Wright, 'Shell Shock', p.34.
} 
Unhappy Home - Mother Dead and Children Neglected' ${ }^{5}$ The article describes how problems in his home started when 'he commenced drinking' when he returned home in April 1918, and that he was 'not cruel [when he was sober] but he was very often drunk' $^{6}{ }^{6}$ His wife had died several weeks before the trial. The newspaper also detailed his abusive behaviour towards his children, which included a time when he had 'struck one of the boys under the chin with an axe handle' and 'called the children filthy names'.7 Here the returned man's alcohol problems clearly stemmed from, or were worsened by his war service. The death of his wife had left the children, along with an uncle, to help the father to supply money to purchase food while the returnee's 15 year old daughter was left to 'keep house' during the day. ${ }^{8}$ One of the boys, Bernard, who was aged 11 had been selling newspapers to help his sister buy food. He stated that his father had tried to take his wages off him but had not succeeded. ${ }^{9}$ This story is doubly tragic due to the neglect that the children, who were undoubtedly grieving over their mother, were subjected to. They had to help run the household under stressful circumstances. They were suffering at the hands of their father, whose war experience had led to his drinking and subsequent aggression and neglect. He was also struggling to cope in the wake of his wife's death, especially given his existing alcohol problem. In this case he was the antithesis of the soldier-citizen, and did not live up to the ideal of the heroic returnee. If it weren't for his violence and his abuse of alcohol he would have been an object of pity and admiration. In this case, the family's plight was brought to the attention of the authorities and the father was subsequently prohibited

\footnotetext{
${ }^{5} E P, 24$ January 1919, p.8.

${ }^{6} E P, 24$ January 1919, p.8.

${ }^{7} E P, 24$ January 1919, p.8.

${ }^{8} E P, 24$ January 1919, p.8.

${ }^{9} E P, 24$ January 1919, p.8.
} 
from drinking with the consequence of going to prison if he flouted these rules. ${ }^{10}$ Given that he was still the primary caregiver to his children, it was unlikely that he would be able to be sent away for treatment.

Christopher Pugsley, when writing about disciplinary problems in the New Zealand forces during World War I, noted that the 'principal offence was drunkenness and the case histories show that officers, like soldiers, turned to drink to escape the pressures of war. ${ }^{11}$ Consuming alcohol was one of many ways of relieving stress and anxiety. For many soldiers, a drink or a few drinks was a way to relax after a hard day; for some it was a means to alleviate boredom. One could argue that the consumption of alcohol helped many men at points of their war experience to cope with the stresses they faced or to unwind and forget some of the horrors of war. However, for some men alcohol became a crutch; it was a form of escapism, and a relaxant that some became reliant on. Len Wilton observed a fellow soldier at the front, 'He was telling me that he had taken to smoking a lot \& also the drink. ${ }^{12}$ Most men, on returning home, did not consume large amounts of alcohol; some of those who had been heavy drinkers at the front may have given this up after the war for various reasons. However, some men did continue to drink, whether this was privately or more visibly. Also, for many returned men, the RSA became a place to gather and find fellowship among soldiers. The RSA also had something of a reputation for providing alcohol; undoubtedly many men did use the RSA's facilities to drink to excess, particularly if this was cheaper than other means. The RSA Quick March contains few references to alcohol, however. It does contain advertisements related to the prohibition

\footnotetext{
${ }^{10} E P, 24$ January 1919, p.8.

${ }^{11}$ Christopher Pugsley, On the Fringe of Hell - New Zealanders and Military Discipline in the First World War, Auckland, 1991, p.73.

12 Len Wilton, Letter to Ilma McLachlan, 5 August 1917, in Beth Sutherland (ed.), My Dear Chick - A New Zealand Love Story 1911-1948, Masterton, 2008, p.160.
} 
movement, but these are in support of all three of the voting options for the 1919 referendums, not just one. Its mention of soldier alcoholics is limited but does appear. This includes a small article on the formation of an advisory committee on soldier alcoholics, and the visit of a deputation to Roto Roa inebriates rehabilitation centre. ${ }^{13}$ In October 1920 a report stemming from the Roto Roa visit was published in Quick March, in which the RSA blamed 'the exhausting stress of war' for driving some men to drink. ${ }^{14}$ This appears to be the first time that the RSA addressed soldier alcoholism directly in an article. The writer noted that 'The committee expresses a hope that friends of men, who are handicapped in life by the drink trouble, will urge them to take a curative course on the island. ${ }^{15}$ The article mainly concerns the conditions on Roto Roa island, and the RSA's recommendations on the institution as it is. It appears the RSA was planning to take a more involved approach at this point; it suggested that men who were drinking to the point of disturbing their ability to live their lives normally could meet with local representatives of the RSA 'with a view to influencing them to control their actions in this respect' and could have them sent to another district that was far from licensed premises. ${ }^{16}$ If this failed, the soldier would then be committed to Roto Roa. ${ }^{17}$ Another important recommendation was the push for public 'propaganda' on the work being done at Roto Roa, therefore raising awareness that treatment was available and in many cases successful. ${ }^{18}$ This would take the pressure off the Government to provide an institution for soldiers themselves. The RSA's advocacy for treatment of alcoholism and its encouragement through its Quick March magazine to seek help suggests that it saw alcoholism as a war related disability.

\footnotetext{
${ }^{13}$ QM, 10 March 1920, p.69, \& 10 September, 1920, p.69.

${ }^{14}$ QM, 11 October, 1920, p.47.

${ }^{15} Q M, 11$ October, 1920, p.47.

${ }^{16} Q M, 11$ October, 1920, p.48.

${ }^{17} Q M, 11$ October, 1920, p.48.

${ }^{18}$ QM, 11 October, 1920, p.47.
} 
The views of the Defence Department in 1920 show the difficulty of ascertaining both the cause and the scale of alcoholism among soldiers, and their reluctance to treat it as a war related condition. It is difficult to say whether or not soldiers became alcoholics because of their war experiences, merely because, as the Defence Department argued, many of the men who were returned alcoholics may have had problems with alcohol before enlisting, or were predisposed to this problem. The Defence Department was reluctant to take on responsibility for alcoholics. This was a similar issue to TB sufferers, detailed in the next chapter, and shows the inability of the department in these cases to put in place specific limits on who qualified for pensions and treatment. It is also difficult to ascertain the scale of the alcoholism problem. There was much disagreement among various community organisations and departments over whether returned soldier alcoholism was a significant issue. The government's lack of resources to treat alcoholic men is shown in no better way than their decision to send alcoholic men to a shell shock treatment centre. ${ }^{19}$ Furthermore, the government's ability to state that alcoholism was not caused by war service removed any responsibility to provide treatment options. How many returned soldiers, and their families, suffered in silence is impossible to guess. Given the stigma that alcoholism has, and perhaps a desire to 'keep up appearances' to the community, it is possible that numerous men suffered alcoholism in silence, and that their wives and children suffered along with them - monetarily, emotionally, and in some cases, physically. The effects of alcoholism on the wider family cannot be underestimated, and undoubtedly would have traumatised family members to varying extents.

${ }^{19}$ Weaver and Wright, 'Shell Shock', p.34. 
Public fears of soldier drunkenness were already in place, and those who committed crime under the influence were sometimes exposed in newspapers. The government was fearful of the effects of drunken returned men on society, and made enquiries into the scale of the problem and potential treatments. It is likely that some of these fears stemmed from the prohibition debate, and in particular, the referenda of 1919 over whether or not New Zealand should be subject to prohibition of alcohol, or continuance. The April referendum in 1919 was in favour of continuance; the 49 percent vote for prohibition was kept just below the 50 percent required due to the votes of overseas servicemen, 80 percent of whom voted for continuance. ${ }^{20}$ Due to the soldiers making special votes, it was clearly identifiable at the time which way soldiers had voted. In December 1919, another referendum came closer to bringing prohibition into law, with the vote increasing to 49.7 percent. ${ }^{21}$ The debate continued into the 1920s; a 1922 referendum received just under 49 percent in favour of prohibition. ${ }^{22}$ What is clear is that there were widespread fears and tension over the issue of alcohol and its consumption. The belief that alcohol was the root cause of many societal problems had been steadily growing, with the activities of the Women's Christian Temperance Union well established. The extent to which this affected women and children was a concern to groups such as the Society for Protection of Women and Children, as well as the WCTU. Their lobbying for prohibition of alcohol and other measures to reduce the effects of liquor on society had been underway for much of the early twentieth century, was obviously effective, and was related to the incidences

\footnotetext{
${ }^{20}$ Paul Christoffel, 'Prohibition and the Myth of 1919', New Zealand Journal of History, vol.42, Is.2, 2008, p.154.

${ }^{21}$ Christoffel, 'Prohibition', p.159.

${ }^{22}$ Christoffel, 'Prohibition', p.161.
} 
of alcohol-related abuse and disruption of lives they saw in their local communities. ${ }^{23}$ The WCTU was established in 1885 , and grew quickly in size and influence. ${ }^{24}$ Debates around alcohol were firmly established by 1914, and the establishment of six o'clock closing during the war shows the influence that the WCTU and prohibition movement had in society. ${ }^{25}$ Soldiers were identified as threats to the ideal of an alcohol free society as their votes prevented prohibition in April 1919. Stories that had come back from the front concerning drunken soldiers misbehaving, or the availability of alcohol to soldiers overseas, no doubt added to fears that soldiers would behave badly on return. Indeed, the soldier vote in 1919 was blamed for low proceeds during a street collection for the RSA in Christchurch, with some collectors stating 'they had met with rebuffs..."because the soldiers had voted against prohibition"', ${ }^{26}$ If this was indeed true, it shows that soldiers occupied an ambivalent position for some prohibition supporters.

The 1919 referendum was not the only factor that brought soldiers into the prohibition debate. Newspapers reveal there was some debate before the end of the war over soldier drinking, and this further affected perceptions of returned men. By the end of the war, associations between soldiers and alcohol were entrenched. An article in the Colonist detailed that in 1915 the WCTU had put forward a resolution that all soldiers in uniform should be prohibited from drinking alcohol; the Methodist conference in 1915 had put forward a resolution for the same. It also gave details of a speech by Rev. Scorgie at the Dunedin Presbytery in 1915 stating that 'Young men's names were being placed on rolls of honour...the next thing they heard was that these

\footnotetext{
${ }^{23}$ Margaret Tennant, 'Matrons With a Mission: Women's organisations in New Zealand 1893-1915', Masters Thesis, Massey University, 1976, p.38

${ }^{24}$ Tennant, 'Matrons With a Mission', p.39a (pagination error)

${ }^{25}$ Tennant, 'Matrons With a Mission', p.51.

${ }^{26}$ CST, 29 April 1919, p.5.
} 
men were seen drunk ${ }^{\prime 27}$ Underlying such statements and resolutions was the fear that those who were fighting valiantly for the country were besmirching such deeds with their drunkenness; furthermore, these men were harming their chances of being efficient and effective soldiers through their drinking. In 1919, the National Efficiency Board, who stated that alcohol lessened the efficiency of those who drank it, faced arguments by those who pointed out 'Do you even think that [the rum ration] would be issued if its after effects lessened the efficiency of the soldier? ${ }^{28}$ The mass soldier vote against prohibition was also explained in terms of soldiers' psyche after the war and their experiences overseas, and they were described as too 'broad minded' to accept prohibition. ${ }^{29}$ On the other side, returned soldiers, often of higher rank, were sometimes brought in to speak on the benefits of prohibition due to what they had seen at the front. One such speaker stated that

greater efficiency would have been attained if liquor had not been available...Ninety per cent of the serious crimes in the ranks was caused directly through drink. It was estimated that 20,000 men were continually incapacitated behind the lines due to this cause. ${ }^{30}$

This high estimate of the men who had been taken away from front line fighting due to alcohol's effects was aimed at raising questions over how much better some battles could have gone were those men at the line; it further served to perpetuate stereotypes of drunken soldiers and in some ways blame them for the length of the war or lack of success on some battlefronts. Inflammatory comments were made by

\footnotetext{
${ }^{27}$ CST, 16 Dec 1919, p.7.

${ }^{28}$ NZT, 17 May 1919, p.4.

${ }^{29}$ NZT, 17 May 1919, p.4.

${ }^{30}$ HNS, 15 December 1919, p.5.
} 
the Rev. Gray in Invercargill in early 1919, where he stated that soldiers 'with the taste of liquor in their mouths.... were returning nerve shattered and morally weak' ${ }^{31}$

Unfortunately for those men who were yet to return to New Zealand in 1919, some men who had returned prior to the war's end had been attracting media attention with their drinking. A 'Regrettable Scene at ANZAC Dinner' was reported in May 1918, after a 'considerable number' of returned soldiers arrived at an RSA dinner under the influence of alcohol. ${ }^{32}$ It was stated that 'after less than half an hour the men were quite out of hand and it was decided that the dinner had better be closed down....The scene was disgraceful'. ${ }^{33}$ The article went on to state that if such behaviour continued among soldiers, the RSA would lose members and eventually fail. ${ }^{34}$ Another article, published in July 1918, described 'Riotous Behaviour' in Wellington by 'Wounded Soldiers'. ${ }^{35}$ The men had just arrived in Wellington, and it was described that 'Many wounded and sick men were seen staggering along in a drunken condition', 'Many free fights took place in the streets', and that this carried on over two days. ${ }^{36}$ Incidents such as these surely gave soldiers a bad reputation, and also caused the public to wonder what would happen when soldiers returned en masse at the conclusion of the war. When soldiers did return, alcohol was an issue which again graced newspaper headlines - this time concerning alcohol on troop trains. A reminder was published by Sir James Allen, Minister of Defence, that alcohol on troop trains was prohibited. He cited correspondence received from a civilian stating 'Only a few days ago a weeping mother was seen guiding her staggering boy along our railway

\footnotetext{
${ }^{31}$ NZT, 25 January 1919, p.5.

${ }^{32} M E, 4$ May 1918, p.2.

${ }^{33} M E, 4$ May 1918, p.2.

${ }^{34}$ ME, 4 May 1918, p.2.

${ }^{35}$ HNS, 2 July 1918, p.8.

${ }^{36}$ HNS, 2 July 1918, p.8.
} 
platform' ${ }^{37}$ Consideration had been given to closing 'hotel bars close to railway stations when trains carrying soldiers were going through' but this was regarded as too difficult. ${ }^{38}$ The emotive image of the weeping mother and her drunken son was used as a motivator for support of such measures. In this case, the homecoming imagined by the soldier's mother had been taken from her by the actions of her son.

The issue of returned men and alcohol post World War One is somewhat complicated due to subjective ideas of 'heavy drinking'; how does one distinguish between social drinking and drinking to excess among men? Excess drinking is very much 'in the eye of the beholder'; what would be unhealthy to one person would be considered normal by another. The limits on what was unhealthy can be difficult to define, and this is why many of those who suffered the effects of alcohol addiction, particularly on their health, did so silently while those around them did nothing to stop it. All too often excess drinking was only defined as such when others were harmed or affected. In contemporary literature on alcoholism it is generally agreed that high consumption of alcohol, deviant behaviour - including failure to support a family, or to work - and negative effects on health are all signs of alcoholism. ${ }^{39}$ However, as a counter to this, it is acknowledged also that society and peers also can determine what is not acceptable drinking. ${ }^{40}$ Given that temperance was a popular cause in the 1920 s, drunkenness was deemed as unacceptable by greater society in New Zealand. However, amongst certain peer groups, heavy drinking may have been acceptable, hence the silence around soldier alcoholism.

\footnotetext{
${ }^{37}$ PBH, 1 April 1919, p.5.

${ }^{38}$ PBH, 1 April 1919, p.5.

${ }^{39}$ Nick Heather \& lan Robertson, Problem Drinking, 3ed., Oxford, 1997, pp.125-6; Jean-Charles Sournia, A History of Alcoholism, Oxford, 1990, p.102; \& Margaret J. Sargent, Alcoholism as a Social Problem, St. Lucia, 1973, pp.29-30, all contain similar definitions for alcoholism, as did wider reading in the subject.

${ }^{40}$ Sargent, Alcoholism p.27, Heather \& Robertson, Problem Drinking, p.125.
} 
Those who are not revealed in the historical record were those who drank to excess quietly, evading the attention of authorities or the media. It is likely that many families stayed silent on the issue of their alcoholic returned man, or were unsure where or if to get help. It is quite possible that some men were functional alcoholics; holding down employment and seeing friends on a regular basis who were unaware or unsure if they were dependent on alcohol. Given the reputation for soldiers being drinkers, it is likely that some returned men were seen as merely fulfilling a stereotype, with no real harm done - their issues may have been overlooked or allowed for because they were traumatised returned men and alcohol was seen to ease this trauma. For some, their problem became public - they committed a crime, became unable to function, or attracted the attention of those concerned with soldier welfare. It is only then that these men become visible in the historical record. Soldier alcoholism was a more widespread problem than is recorded in the media or archives, quite simply due to the ability to hide it and the embarrassment that many men and families would have felt at declaring the problem. Furthermore, oral histories point towards awareness among returned men that there were those who were heavy drinkers and that these men were giving other soldiers a bad reputation. The interviewees are quick to label themselves as light or non-drinkers, suggesting sensitivity around the subject and an unwillingness to identify with the stereotype.

None of the soldiers in my oral history interview sample considered themselves heavy drinkers, yet some identified that there had been a soldier drinking problem, and could also define what heavy drinking meant to them. Opinions varied on the seriousness of the returned soldier drinking problem, both at the time and years after the fact. Arthur Emmins stated that 'I'm not a heavy drinker, I'm not a drinker. I 
haven't done a drink of beer for about 5 years and I haven't had a glass of wine for about 3 years...so you can't call me a heavy drinker. ${ }^{41}$ Emmins does not comment on his drinking habits when he was younger, but it appears that he was not a heavy drinker post-war. Emmins complained about the RSA putting its subscription rates up so it could sell beer to men 'at a cheaper rate than what they could buy it in the pubs. $^{, 42}$ Making such a comment shows that he was not altogether interested in drinking; if so he likely would have been pleased at such a development, rather than feeling that it was unfair to him and potentially unethical - particularly as he was not making use of it. Wilfred Davies also denied drinking much - when confronted with the idea that soldiers had a bad name for drinking, Davies replied 'Did they? Well I wasn't one of them. I never had that much. ${ }^{43}$ Davies did not deny drinking - it is mentioned earlier in his interview - but he did not class himself as drinking to excess. Similarly, Jack Gregor stated that 'I've never been a drinker. I have a glass of beer or two beers. ${ }^{44}$ In all of these instances there is a clear demarcation between drinking socially and being a 'drinker', which is classed as drinking to excess. While these soldiers were aware that excess drinking was occurring, they were clear that they were not a part of it. Another returned man, Charles Hartley, was clear on his reasons for not drinking. He stated that

I wasn't a drinker. Well when I say I never drank, I saw too much of it. I worked with fellers and they'd get a cheque and go to the pub and bust the lot. Work

\footnotetext{
${ }^{41}$ Arthur Emmins, interview by Jane Tolerton and Nicholas Boyack, 21 September 1988, for the World War I Oral History Archive, held in the Oral History Centre, ATL, OHC-002622.

${ }^{42}$ Emmins, OHC-002622.

${ }^{43}$ Wilfred Davies, interview by Jane Tolerton and Nicholas Boyack, 4 December 1988, for the World War I Oral History Archive, held in the Oral History Centre, ATL, OHC-002607.

44 Jack Gregor, interview by Jane Tolerton and Nicholas Boyack, 6 August 1988, for the World War I Oral History Archive, held in the Oral History Centre, ATL, OHC-002643.
} 
hard, good men, good workers, but you see, got them down. That's why I knocked off drinking. I was brought up to drink. ${ }^{45}$

Hartley saw drinking as a waste of money and saw how it affected those who chose to drink heavily, particularly their dependence on alcohol, and the weakness that this represented to him. He even states that it was in his upbringing to drink heavily; choosing not to was clearly from seeing the effect it had on others. He could also see the cycle of working hard and then spending all the profits on alcohol was wasteful; Hartley clearly had ambitions for his money and time and did not want to undertake what he saw as a wasteful pastime. Here Hartley is more open than some of the other soldiers over his own reasons for not drinking and also that there was a drinking culture within his family and group of friends, that he was perhaps involved with to some extent before coming to the realisation that he shares in the interview.

The fact that these interviewees did not consider that they were heavy drinkers and were even against heavy drinking is significant. It shows that while there was a public perception that returned soldiers loved to drink, there were a number of returned men who had little or no interest in drinking to excess, but were aware that soldiers had this reputation. The fact that these men are quite specific - often citing facts such as the number of drinks they have had recently or how much they generally drank throughout their lives - shows that they do not want to be classed as 'drinkers', and also have a very clear idea of what a drinker consists of. These men reached a good age and led reasonably successful lives and this further shows the ways that moderate drinking habits can complement a healthy and productive lifestyle. There is also the consideration that these men perhaps did drink more than they let on; yet

\footnotetext{
${ }^{45}$ Charles Hartley, interview by Jane Tolerton and Nicholas Boyack, 22 September 1988, for the World War I Oral History Archive, held in the Oral History Centre, ATL, OHC-002649.
} 
perhaps they did not want to be classed under a stereotype of a soldier drinker, or would not disclose this for privacy reasons. Either way, the men interviewed were presumably not heavy drinkers in later life, and were well aware of the dangers and stigmas of alcohol, particularly when related to soldiers. This awareness suggests that they were not being untruthful about their alcohol consumption.

The RSA's role in New Zealand was to cater to the needs of returned men and to provide a place for them to come together, but in the 1920 s the reputation of the RSA began to revolve around its provision of alcohol and a drinking culture that became increasingly apparent. The RSA advocated for returned men and some branches ran activities for their men. There were many RSA clubs around the country, some small, some large, and all run in varying ways. Yet the RSA had a reputation for providing places for soldiers to drink to excess. When asked in later life, returned men noted that their perceptions of the RSA often involved alcohol, with Frederick Dill remembering 'Most functions they had there was always a lot of drinking, that sort of thing. ${ }^{46}$ When Wilfred Davies, a member, was asked what went on at RSA functions, he stated 'beer drinking'. ${ }^{47}$ Two other men were put off joining the RSA due to its reputation and stance on alcohol. Charles Hartley, when asked if he joined, stated 'No, I never. Because of the booze. I wasn't a drinker...If it hadn't been for drink, I might have joined. ${ }^{48}$ Arthur Emmins resented his local RSA's subsidy on alcohol. ${ }^{49}$ James Miller also commented on the RSA's drinking culture, stating that 'there are good sides of RSA, and there are others, the Booze artists'.$^{50}$ All of these experiences point to

\footnotetext{
${ }^{46}$ Dill, OHC-002611.

${ }^{47}$ Davies, OHC-002607.

${ }^{48}$ Hartley, OHC-002649.

${ }^{49}$ Emmins, OHC-002621.

50 James Miller, interview by Jane Tolerton and Nicholas Boyack, 14 May 1988, for the World War I Oral History Archive, held in the Oral History Centre, ATL, OHC-002700.
} 
some RSA clubs having a drinking culture throughout the twentieth century, and that this put some men off joining, while others who were members certainly noticed that drinking was a popular pastime. On the one hand they provided alcohol but also helped with the administration of those who needed treatment on the other. This is manifest in the presence of advertisements for a treatment for alcoholism and for alcohol itself in its publications. The product, called 'Drinko', purported as a cure for excess drinking appears in the pages of Quick March in 1920, yet advertising for Begg's Whisky lined the top and bottom of the pages in the RSA Review (the successor of Quick March) in 1924 and 1925 - it appears that Begg's was the main sponsor of the Review at this time. ${ }^{51}$ This is a paradox which is noted by Stephen Clarke, the current Chief Excecutive of the RSA, in an article covering the history of the RSA from 19161922. He notes that,

The RSA was itself concerned with the problem of alcoholism among returned soldiers....This perhaps explains the advertisement in Quick March for 'Drinko'....which appeared, ironically, on the same page as advertisements for various brands of beer and liquor. ${ }^{52}$

The RSA was reluctant to take a firm anti alcohol stance. While it was able to recognise and participate in discussions that stated that alcohol was addictive to some returned men, in many ways its provision of alcohol and its advertisements for alcohol in later years alienated temperate soldiers from participation in the RSA. Its suggestion of removing those with alcohol addiction to areas where there were no licensed premises immediately alienated those men from attending many of the RSAs around the country. It was an advocate of "social drinking" by its action of providing alcohol in a

\footnotetext{
${ }^{51}$ QM, 10 August 1920, p.31, \& 10 June 1920, p.53; \& NZRSA Review, Vol.1, No.3, February 1925, p.12 (as example).

52 Stephen Clarke, 'Return, Repatriation, Remembrance and the Returned Soldiers' Association 1916-22, in John Crawford \& Ian McGibbon (eds.), New Zealand's Great War, Auckland, 2007, p.170.
} 
social situation; the fact that binge drinking undoubtedly took place in some clubs is overlooked in discussions about alcoholic returnees, although Clarke admits that

RSA members themselves were far from teetotal...a number of veterans indicated that heavy drinking was part of the culture of some RSA clubs during the 1920s. Such cliques of heavy drinkers were a legacy of the war.... ${ }^{53}$

There was never a suggestion by the RSA at this time that the focus of alcohol in some clubs was undermining the ability of some men to abstain or drink alcohol moderately. Undoubtedly a stance against excessive alcohol consumption or a ban on alcohol at the clubs would have been unpopular in many cases, yet there were clubs that did not provide alcohol. The RSA chose to operate on the basis that the majority of men attending the clubs were drinking in moderation and that they were not responsible for enforcing measures to ensure binge drinking did not occur. Nor were they responsible for not advertising alcohol. The RSA, like the Army, saw alcohol abuse as a private weakness and an individual's responsibility.

Using government records it is possible to piece together a picture of how returned men's drinking habits were being noticed and were affecting others. In early 1918, before conflict had ended, a deputation from the Southland War Funds Association met the Minister of Defence, stating that a government alcoholics' institution was needed for returned men who were addicted to alcohol. They used the example of one man who was 'a good fellow before the war...now reported to be drinking himself to death' ${ }^{54}$ The War Funds Association wrote to the Assistant Director of Medical Services, Colonel Falconer, with a list of ten returned men that they considered would benefit from treatment for alcoholism, along with the opinion that

\footnotetext{
${ }^{53}$ Clarke, 'Return, Repatriation, Remembrance', p.170.

${ }^{54}$ Deputation to the Minister of Defence at Invercargill, 11 February 1918, in Medical - Alcoholism among Returned Soldiers - Treatment - 1918-1921, AD1 49/791, Archives New Zealand, Wellington.
} 
they would be able to provide many more names if they checked with other centres in the province. ${ }^{55}$ Relief societies also registered their concerns over drunken returned men in 1918 and 1919. The War Relief Association of Wellington stated that they apply to us for relief and very often are most abusive because we refuse to do anything ${ }^{\prime 56}$ The chairman wrote of their experiences with these men, noting the recent case of a returned man who had been abusive under the influence of alcohol when asking for relief, pointing out that 'he had done very good work at the Front [so] we did not like to send for the Police and have him arrested'. ${ }^{57}$ The society did not know what else to do for the man. This dilemma was likely to have faced others who were confronted with alcoholic men, and suggests that there were a number of men who were effectively evading any kind of public recognition of their illness. The Hawke's Bay War Relief Association's Dannevirke branch wrote that they had 'several soldiers who are badly addicted to drink' in their district and asked if there was any way to deal with these cases. ${ }^{58}$ That relief societies were seeing many of these men also suggests that their bad financial position was caused by their drinking, or that they were already struggling for money and that this stress exacerbated their drinking problem. For these two relief societies, seeing numbers of men in this position was clearly distressing and they asked for the Government's help. This, along with other investigations, led to a decision by General G.S. Richardson of the Defence Department to make a decision that an institution needed to be provided for alcoholics. ${ }^{59}$ The

\footnotetext{
55 Letter to Colonel Falconer, ADMS, 13 April 1918, in Medical - Alcoholism among Returned Soldiers Treatment - 1918-1921, AD1 49/791, Archives New Zealand, Wellington.

${ }^{56}$ Letter to Sir James Allen, Minister of Defence, 9 August 1918, in Medical - Alcoholism among Returned Soldiers - Treatment - 1918-1921, AD1 49/791, Archives New Zealand, Wellington.

${ }^{57}$ Letter to Sir James Allen, Minister of Defence, 9 August 1918, AD1 49/791, Archives New Zealand, Wellington.

${ }^{58}$ Letter to Sir James Allen, Minister of Defence, 14 April 1919, in Medical - Alcoholism among Returned Soldiers - Treatment - 1918-1921, AD1 49/791, Archives New Zealand, Wellington.

${ }^{59}$ Extract from letter to Mrs A.R. Bodee from Gen. G.S. Richardson, 3 July 1919, in Medical - Alcoholism among Returned Soldiers - Treatment - 1918-1921, AD1 49/791, Archives New Zealand, Wellington.
} 
government's file on alcoholism does not give any further details of the plight of returned men - in 1919 and 1920 Richardson's committee was focussed on finding a solution to treatment for alcoholic returned men, and this dominates correspondence. This eventually ended with the solution detailed in the RSA's article which has been discussed in this chapter - that men would be sent to Roto Roa Island, and with recommendations on how Roto Roa should be run. Sadly, a spell in the 'rehab' centre was not necessarily the solution for many men. There was still the problem of committing men to the institution - these men had to be noticed by the authorities and then induced to go into treatment; Weaver and Wright's observation that 'troublesome' alcoholic men were sent from hospitals to Hanmer, a shell shock treatment centre, with false or incomplete paperwork shows that there were problems obtaining effective treatment for these men, and that those who were dealing with these men were at a loss. Furthermore, rehabilitation treatment, in many cases, did not work.

Returned soldiers were easily identifiable by their uniforms, and this could lead to problems for soldiers trying to abstain from alcohol. Returnees could spend a month or more in New Zealand before being discharged from the Army. An unnamed subinspector for the Auckland police recounted the case of a returned man who was suffering from shell shock and whose consumption of 'the smallest quantity of alcohol sent him into a frenzy of violence under the influence of which he assaulted his relatives and smashed up the furnishings of his mothers house' ${ }^{60}$ Despite help being requested by his family and several attempts at treatment, the soldier could not reform, stating that 'his chief difficulty lay in his being in uniform as by that he was

\footnotetext{
${ }^{60}$ Letter to superintendent of Auckland police, 13 July 1918, in Medical - Alcoholism among Returned Soldiers - Treatment - 1918-1921, AD1 49/791, Archives New Zealand, Wellington.
} 
recognised as a returned soldier and pressed to drink when he knew he should not. ${ }^{61}$ Once he was discharged from the forces and gained employment, he improved immensely. ${ }^{62}$ In this case, the soldier blamed his identity as a returned man on the accessibility of alcohol and this correlates with some of the claims of a soldier drinking culture. It also raises questions over civil society's role in encouraging these men to drink; his uniform gave him status in society, and it is possible that civilians were buying him drinks as a gesture of gratitude over his war service; it is also possible he was joining in the celebrations that other returned men held when they came home. It was the opinion of one medical superintendent that 'misplaced hospitality' caused some cases of alcoholism. ${ }^{63}$ In this man's case, the removal of his uniform was also a distancing from the lifestyle associated with returned men, and a resumption of a civilian persona. His securing of employment also gave him responsibility and undoubtedly helped him to stay sober - although in many cases, for men, this was not enough.

The media reported soldier drunkenness with no censorship, which further drove fears and stereotypes of soldier drinking. These reports ranged from magistrates' reports of public drunkenness and disorderly behaviour, to longer reports of domestic abuse, violence, and serious crimes committed by returned soldiers under the influence of alcohol or with a record of alcoholism. This was despite efforts to persuade the press to avoid making such associations. An article in the Evening Post in May 1918 containing a Magistrate's comments on returned soldiers and their drunken

\footnotetext{
${ }^{61}$ Letter to superintendent of Auckland police, 13 July 1918, AD1 49/791, Archives New Zealand, Wellington.

${ }^{62}$ Letter to superintendent of Auckland police, 13 July 1918, AD1 49/791, Archives New Zealand, Wellington.

${ }^{63}$ Memo from Theo Gray, acting medical superintendent, to Lieut. Falconer, Assistant Director of Medical Services, Otago, 8 April 1918, in Medical - Alcoholism among Returned Soldiers - Treatment 1918-1921, AD 1 49/791, Archives New Zealand, Wellington.
} 
disorderly behaviour, included the request to 'the press to refrain from any unnecessary use of the term 'returned soldier' in association with men charged with crime. ${ }^{64}$ He explained that

the use of the words 'returned soldier' in relation to these offenders tends to smirch the term and create a feeling of suspicion among the public in regard to returned men as a class. This is distinctly unfair. ${ }^{65}$

Despite this urging, the newspapers continued to specify when returned soldiers were charged for drunkenness and other misdemeanours. Reports of the happenings at the Magistrate's Court in 1918 and 1919 contained references to returned soldiers arrested for drunkenness. However, after this time such reports are replaced with individual reports of drunken soldiers or as part of a larger article on a serious crime committed by an intoxicated veteran.

The media's insistence on reporting returned soldiers' drunken misdemeanours well into the 1920s shows that there was a certain importance attached to this information by the media, and an interest in it by the public. Through viewing these sources, it is apparent that there was a perception of returned soldiers as having a tendency towards excess consumption of alcohol and, attached to this, disorderly behaviour and violence while under its influence. Returned soldiers were visible when behaving in a disorderly fashion while still in uniform; such behaviour immediately after return helped reinforce such stereotypes, and made further reporting play in to public expectations of soldiers' behaviour. Indeed, this was feared in 1918, when the same Magistrate who urged the press to refrain from reporting unnecessarily on returned soldier convictions pointed out that 'the proportion that may abuse liquor

\footnotetext{
${ }^{64} E P, 16$ May 1918, p.8.

${ }^{65}$ EP, 16 May 1918, p.8.
} 
can easily bring discredit on the great majority of soldiers among persons who do not pause to get the facts in right perspective' ${ }^{66}$ The Dunedin RSA also forwarded a complaint from returned men that the press was using the words 'returned soldier' when reporting arrests or other misdemeanours. They opined that

the Press Association seems to delight in rubbing in the fact that the man is a returned soldier, and therefore is only one more example to prove that the 'diggers' as a whole are no good. Of course, we know that we are no good. Ask the prohibition party - but why rub it in ${ }^{67}$

Despite these complaints, reporting of returned soldiers' misdemeanours continued, and the stereotypes of drunken returnees consolidated.

Reports of soldier drunkenness also revealed the negative effects of soldier drinking on family life, including family and relationship break ups. The NZ Truth printed one such report of this kind in 1927. This was eight years after war's end, yet the fact that the man in question was a returned soldier 'with a crippled arm' was still reported on. His marriage, which was a focus of the case, had begun in 1922 and it appears his alcohol addiction worsened over the five years since. ${ }^{68}$ He was accused as being a 'drunkard' who, when drinking, 'would pick a quarrel with anybody, and disturb the whole neighbourhood. ${ }^{69}$ In this case, the mention of his arm suggests the media considered his disability was the reason for his excessive drinking, or at least naming it as a factor. Yet the fact that he was disturbing 'the whole neighbourhood' shows this man's problem was portrayed as a great disturbance to the peace of many, and therefore a public nuisance. For this returned man, his drinking habits were leading to aggression and conflict with others. It was also disturbing his family

\footnotetext{
${ }^{66} E P, 16$ May 1918, p.8.

${ }^{67} A G, 28$ May 1919, p.7.

${ }^{68} N Z T, 6$ January 1927, p.7.

${ }^{69}$ NZT, 6 January 1927, p.7.
} 
situation. It was claimed that under the influence of alcohol he was violent towards his wife and did not provide her and their son with enough money to live on. ${ }^{70}$ The article describes how at one time 'he was half-crazed with drink and she fled to the Society for the Protection of Women and Children'. He also withheld money from her, forcing her to go out to work to provide for their son. ${ }^{71}$ The result of the case was that she was granted custody of their son and given an allowance. ${ }^{72}$ The fact that this woman had suffered over such a long period of time shows the inability or reluctance of others to intervene, often until many parties had been hurt. This returned man had an alcohol problem that led to him being a neglectful husband and father, and meant that he was not providing for his family sufficiently. There is no mention of this man being recommended for prohibition or treatment; therefore it is likely that he continued to abuse alcohol. Another report of a family breakup detailed the story of a woman who had been forced to leave her husband after finding he was drunk often, and 'practically every day came to the place where his wife was working ${ }^{73}$ He was sent to the rehabilitation centre at Roto Roa, but 'it seemed to make no difference to his habits and it was impossible to live with him. ${ }^{74}$ She was granted a divorce on the grounds of desertion. ${ }^{75}$ Sadly, in this case, treatment at Roto Roa and prohibition did not help this man; it appears he was unwilling or unable to stop drinking excessively, and this cost him his marriage.

The severity of punishment for drinking offences varied, but the social and economic implications of a conviction could be severe and impact on the families. An

\footnotetext{
${ }^{70}$ NZT, 6 January 1927, p.7.

${ }^{71} N Z T, 6$ January 1927, p.7.

${ }^{72} N Z T, 6$ January 1927, p.7.

${ }^{73} N Z T, 4$ October 1924, p.5.

${ }^{74} N Z T, 4$ October 1924, p.5.

${ }^{75}$ NZT, 4 October 1924, p.5.
} 
article printed in 1926 told the story of the first man of the year to be imprisoned for drunkenness that year. The returned soldier was arrested on New Years Eve for being drunk and disorderly, and was a first time offender. He had been scuffling with another man, who was fined $£ 2$ for his offences. ${ }^{76}$ This article detailed the protest over this punishment, particularly as the soldier was severely wounded from the war and lost his pension through this conviction. The article states that a meeting on the case 'called by the Returned Soldiers' Association last night was very largely attended' ${ }^{77}$ Another article from 1926 is notable in that it does not mention that the offender was a soldier in the title, only mentioning it in the last sentence of the article: 'Mr Hunt....took into consideration...that Horner had been a soldier and had a wife and young family'. ${ }^{78}$ The soldier, Horner, had been intoxicated in charge of a car and used obscene language, and was fined $£ 100 .{ }^{79}$ While this was a heavy fine, the Judge showed leniency in not sentencing the soldier to jail time due to his family circumstances and his war service. Clearly not all judges had this attitude towards returned soldier offenders. The affects on this soldier's family were lessened as he was not incarcerated; however, they had to shoulder the stress of paying the large fine, and also the embarrassment of his public exposure - Horner may have lost his job over the incident, or faced public ridicule or condemnation from those who knew him.

It is apparent that alcoholism had multiple effects, including family breakups, stress on marriages, violence, money problems, and great anxiety for those trying to help the men. What is present in both government and newspaper sources are the stories of families whose lives were affected negatively by alcoholism. The Women's

\footnotetext{
${ }^{76} E P, 9$ January 1926, p.19.

${ }^{77} E P, 9$ January 1926, p.19.

${ }^{78}$ EP, 26 April 1926, p.10.

${ }^{79}$ EP, 26 April 1926, p.10.
} 
Christian Temperance Union spoke out in 1919 against the alcohol trade which they felt was

doing its deadly work wrecking homes, casting a blight on the lives of children, wives and mothers, and still worse, sending a large number of our brave soldier lads back into the arms of their war-wearied mothers in a drunken condition. ${ }^{80}$

The WCTU felt that there was a large soldier alcoholism problem, or at least were prepared to argue that this was the case to further their cause. Given the public exposure that drunken soldiers received, there would have been little trouble arguing this at the time.

The stories of the above men show that some returned soldiers were drinking to excess in the years after the war. The work of the WCTU shows alcohol abuse was a societal problem pre-World War I, however in the post-war era returned soldiers became linked strongly with these problems. These men drank to cope with war, and returning from war, sometimes found themselves caught up in a drinking culture that revolved around the RSA clubs. Due to this, returned servicemen became targets for prohibitionists. This reputation led to the government taking action. It would not link alcoholism to active service, but it did, to some extent, help returnees with alcoholism by investigating, with the help of the RSA, treatment options, and putting some men into treatment at Roto Roa and Hanmer. This treatment did not work for all, and many men never received treatment at all. Newspaper reports reveal the extreme results of problem drinking. Some men became cruel or neglectful of their loved ones, leaving them in financial strife and alienating themselves from the very relationships that they needed for support. Families also became victims of alcoholism. Abuse of alcohol post-

\footnotetext{
${ }^{80} E P, 9$ October 1919, p.5.
} 
war shows that men were struggling to cope with life on return for a variety of reasons - either due to the stress they had suffered at war, or the disappointment of their lives on return; the changes that they had to go through on return, and the stresses that their post-war lives held could all drive men to drinking to excess. Along with this, a drinking culture existed among some groups of returned men, and it appears that this was aided by some RSA clubs providing cheap alcohol. Sadly, these men's reliance on alcohol, instead of reliance on the help of others, often left them alone. For those who were lucky enough to salvage their personal relationships, damage was done to these vital ties, the very support systems that men needed behind them to tackle the changes of post-war life or to recover from the trauma they had suffered at the front. Alcoholics appear to have either suffered in silence, or had their condition become so problematic that it became obvious to all through their actions, both in general and towards others. 


\section{Chapter Four: Tuberculosis}

I was a very sick man for a long time. ${ }^{1}$

- Wilfred Davies, 1988.

Another significant group of medicalised and stigmatised soldiers were those suffering from tuberculosis. Unlike alcoholism, it was an infectious disease that some men contacted while on active service. Yet tubercular men, like alcoholics, had difficulty linking their illness to war service. They also found that their ailment had devastating effects on their and their families' lives after the war. Tuberculosis was a significant issue for the health system in post World War I New Zealand. It required careful and specialised treatment, and at this time such treatments did not guarantee a cure. Tuberculosis is an infectious disease that causes tubercule lesions in the lungs and can spread to other parts of the body. It is transmitted from person to person from the inhalation of sputum droplets from an infectious or 'active' carrier. It causes chest pain, difficulty moving, coughing, weight loss and fatigue. If it progresses to its final stages, blood may be coughed up and death can occur. Patients who had contracted TB were recommended to undertake hospital treatment, which would lead to a placement in a sanatorium - something which could take some time as there was heavy demand. Tuberculosis treatment was long-term, with sanatorium stays stretching into months and sometimes, although less commonly, years. The treatment and lifestyle that had to be adopted could be very isolating for patients. An emphasis was placed on preventing the spread of the disease to others, and this meant that sufferers had to use separate utensils, dispose of any sputum carefully, and sleep in a

\footnotetext{
${ }^{1}$ Wilfred Davies, interview by Jane Tolerton and Nicholas Boyack, 4 December 1988, for the World War I Oral History Archive, held in the Oral History Centre, ATL, OHC-002607.
} 
porch or tent to make sure they were well ventilated. The sanatorium life was isolating and the return home could involve many changes in lifestyle. This could have a negative impact on marriages, with partners having to sleep separately and having to restrict intimacy in their relationships. The stresses of keeping conditions sanitary would have also taken a toll on some sufferers' relationships, particularly in situations where a spouse was reluctant to take precautions to prevent the infection of others. Those taking care of TB sufferers had to follow strict measures, and may have felt very much like they had been cast into a role they did not expect - that of a nurse and caregiver. TB was not only hard on its sufferers, but also led to difficult lives for their families, particularly in terms of the stigma that such a contagious disease had at this time. Marina Larsson argues that for Australian tuberculosis sufferers' families 'domestic lives were shaped by invalidism, unemployment, and the ongoing threat of infection', and the same argument can be applied to New Zealand's tubercular returnees. $^{2}$ The public viewed TB as a horrifying disease that struck down many young, healthy citizens - much like the 1918 Influenza epidemic. Its indiscriminate reach led to ostracism for sufferers and difficulty reintegrating back into society. For soldiers, these considerations added to the complications of trying to resume life at home after being away for up to four years; furthermore, it cruelly impinged on their lives and in some cases killed men post-war who considered themselves lucky to return home alive.

Tubercular soldiers who, in the view of a medical examiner, were deemed as having a 'prospect of recovery' were to be encouraged into sanatoria. ${ }^{3}$ Those who

\footnotetext{
${ }^{2}$ Marina Larsson, Shattered Anzacs - Living with the Scars of War, Sydney, 2009, p.187.

${ }^{3}$ Letter from James Allen, Minister of Defence, 2 April 1919, in Medical - Consumption and Returned Soldiers - Correspondence - Auckland Local Bodies and Societies 1919, AD 1 49/383/3, Archives New Zealand, Wellington.
} 
were judged as 'chronic 'or 'hopeless' were to be sent to annexes attached to hospitals near the patients' homes. ${ }^{4}$ Returned men who received treatment often had short stays in sanatoria. A 1921 list of returned men and their dates of treatment records an average stay of three to five months. ${ }^{5}$ Wakari and Pleasant Valley Sanatoria were civilian sanatoria that treated returnees. A list of admitted service patients show that patient turnover was high, with 18 patients admitted to Wakari in 1919: 10 were discharged, 2 died and 6 remained. In 192023 new patients were admitted: 5 died and 17 were discharged. ${ }^{6}$ Pleasant Valley yielded similar numbers. In 1919, it admitted 51 patients: 1 died, and 38 were discharged. In 192017 were admitted and 20 discharged - some of whom were remaining patients from 1919 - with no deaths. ${ }^{7}$ The length of stays is not recorded, but it can be ascertained that most patients did not remain in sanatorium care for over a year. This means that large numbers of released patients returned to home environments and had to be cared for, to some degree, there. Patients were released once the disease was arrested, but this did not mean that the men were cured, and some relapsed, potentially having to return to sanatorium care or to observe strict procedures at home. Once an arrested case returned home, measures such as sleeping in a ventilated area, sterilising cooking utensils, and observing proper hygiene were still seen as vital to preventing the spread of disease.

For returned men, stays in sanatoria were frustrating, especially after long periods overseas. Their removal from their families and society added to what had already been a long separation from family and friends. A history of the Cashmere

\footnotetext{
${ }^{4}$ Letter from James Allen, Minister of Defence, 2 April 1919, AD 1 49/383/3, Archives New Zealand, Wellington.

${ }^{5}$ List of Service Patients treated at Te Waikato Sanatorium, 1921, in Medical - Consumption Returned Soldiers General File, AD1 49/383/2, Archives New Zealand, Wellington.

${ }^{6}$ Patients admitted to Wakari Sanatorium Since January, 1919, 1921, in Medical - Consumption Returned Soldiers General File, AD1 49/383/2, Archives New Zealand, Wellington.

${ }^{7}$ Patients admitted to Pleasant Valley since January, 1919, 1921, in Medical - Consumption Returned Soldiers General File, AD1 49/383/2, Archives New Zealand, Wellington.
} 
sanatorium states that 'The men, released from the discipline of military service, wanting to forget the past, and, now living in tantalising sight of home and freedom, did not accept readily the restrictions of this life, still regimented to a large extent' ${ }^{8}$ Indeed, discipline problems were reported by the staff of Cashmere sanatorium in 1919, largely due to the restrictions and discipline of sanatorium life. Some soldiers, due to discipline issues and disagreements with staff, asked to leave and continue their treatment at home, and permission was granted for this in most cases. ${ }^{9}$ Some soldier patients were also expelled from the sanatorium, under instructions to complete their treatment at home. ${ }^{10}$ In the wake of complaints over treatment at the Cashmere sanatorium, including the removal of an officers' mess, an explanation of the soldiers' behaviour was made that 'The psychology of the returned soldier is peculiar, and the psychology of the returned soldier suffering from tuberculosis is very extraordinary. ${ }^{, 11}$ The consideration that returned men did not want to continue a regimented life after the war and that sanatorium life was frustrating due to this is a more likely explanation than a returned soldier's psychology being 'peculiar'. After up to four years away from home, it is understandable that returned men struggled with the disciplinary side of treatment, and resented the regimented sanatorium life with the freedom of home tantalisingly close. It is also likely that the nature of their illness preyed on their minds, particularly cruel to those who had survived the war without injury only to find they were afflicted with an often fatal disease. Some soldiers opted not to undertake treatment. James Miller, on arrival in New Zealand, described how he 'had to report to

\footnotetext{
${ }^{8}$ T.O. Enticott, Up The Hill - Cashmere Sanatorium and Coronation Hospital 1910-1991, Christchurch, 1993.

${ }^{9}$ Letter to DGMS from M. Fenwick, Colonel N.Z.M.C., 3 October 1919, in Personnel - Discipline Cashmere Sanatorium Christchurch, AD1 24/73/240, Archives New Zealand, Wellington.

${ }^{10}$ Letter to DGMS from Sgd. R.H. Makgill, Acting Chief Medical Officer, 15 January 1920, in Personnel Discipline - Cashmere Sanatorium Christchurch, AD1 24/73/240, Archives New Zealand, Wellington.

${ }_{11}$ Memorandum for the A.D.M.S, Canterbury district, from D.G.M.S., 9 September 1920, in Medical Complaints - Cashmere Sanatorium, AD1 49/695/11, Archives New Zealand, Wellington.
} 
the Masterton hospital, and...instead of going to Hanmer Springs in the South Island, I didn't even go to the Masterton Hospital, I'd had enough of hospitals.' ${ }^{12}$ Miller was treated for seven months in England, and clearly had no desire to continue such treatment. His decision to treat himself at home eventually led to him changing his occupation and moving to the country. ${ }^{13}$

Sanatorium life revolved around treatment through wholesome food, open air treatment, and bed rest. ${ }^{14}$ Pukeora sanatorium's treatment plan was described in NZ Truth as 'maximum of fresh air, sunshine, food, and "educative exercise"'. ${ }^{15}$ Sanatorium treatment could be characterised as unpleasant; images of men being subjected to wind gales in open shelters or the boredom of sanatorium life are often prevalent when such treatments are brought to mind. Susan Haugh notes that open air treatment often became unpopular and unpleasant in bad weather, and that some could not stand sanatorium conditions and left early. ${ }^{16}$ Sanatorium treatment also had an isolating effect, with patients sent to treatment centres in locations that were far from central or far from their home, making visits from family very difficult. For example, Pukeora Sanatorium was in a rural area south of Hastings, and Waipiata in a very remote location in Central Otago, on the Maniototo Plains. Haugh points out that visits to Waipiata sanatorium were often 'hard to facilitate' due to the 'isolation of the area and lack of affordable boarding accommodation' ${ }^{17}$ The ability of those with a tubercular loved one to visit could be hampered by the difficulty and expense of travel

\footnotetext{
12 James Miller, interview by James Tolerton and Nicholas Boyack, 14 May 1988, for the World War I Oral History Archive, held in the Oral History Centre, ATL, OHC-002700.

${ }^{13}$ Miller, OHC-002700.

${ }^{14}$ Larsson, Shattered Anzacs, p.185.

${ }^{15}$ NZT, 17 January 1925, p.5.

${ }^{16}$ Susan Haugh, 'The Hill of Health: Aspects of Community at the Waipiata Tuberculosis Sanatorium, 1923-1961', Health \& History, Vol.11, No.2, 2009, p.4

${ }^{17}$ Haugh, 'The Hill of Health', p.4.
} 
to remote areas. This meant that those in sanatorium treatment could be separated from family for months at a time if visits were not possible.

For those who had to carry out this treatment at home, or continue to practise precautions post sanatorium treatment, life could quickly become complicated, with the smallest of tasks having to be rethought. A significant number of TB patients undertook treatment at home, with Susan Haugh arguing that most TB patients had to be treated this way due to lack of space in sanatoria. ${ }^{18}$ Soldier tubercular cases came under the care of the state and were provided for by the government, including the provision of sanatorium treatment. However, some men for various reasons may not have undertaken sanatorium treatment, choosing to treat their illness at home. If places were limited in sanatoria or sufferers could not go into treatment for personal or family reasons, home treatment was often the only choice. For families who had little money, particularly in cases where soldiers were unable to work, this could prove extremely difficult. One example of this is expressed by Haugh, who notes the case of a 'twenty-nine-year-old returned serviceman [who] was living on a pension, unable to work, in a single room apartment in the city centre with his wife and six children. ${ }^{19}$ This man was advised to move into the suburbs with his family, yet doing so failed to help him, and he died two years later. ${ }^{20}$ Here poverty was clearly a factor in his home treatment, along with the size of his family - his wife may have needed his help with the children. Arguably this inability to access sanatorium treatment cost him his life, and would have made his wife and children's lives busier and more stressful as attempts were made to treat him in the home.

\footnotetext{
${ }^{18}$ Haugh, 'The Hill of Health', p.14.

${ }^{19}$ Haugh, 'The Hill of Health', p.16.

${ }^{20}$ Haugh, 'The Hill of Health', p.16.
} 
For the recovering TB man, life at home was full of new routines and precautions which made domestic life somewhat similar to the sanatorium. The medicalisation of families who were caring for tubercular soldiers can be easily seen through reading an article in the Quick March which gave 'Hints for Sanatorium Nurses' ${ }^{21}$ A poster which was also printed as an advertisement in some publications advised sufferers to

(d.) Have your blankets and bedding thoroughly exposed to sun and air at frequent intervals. Remember that Nature's great disinfectors are sunshine and fresh air.

(e.) Always sleep alone in a separate room or sleeping-porch

(f.) Always see that your dishes and table utensils are disinfected or "scalded" after each time of use.

...(h.) In particular avoid any possibility of infecting children. Do not allow them to play or sleep in your room. Do not fondle or kiss them. Remember that children are more easily infected than adults. ${ }^{22}$

What is noticeable in these instructions are the ways that intimacy had now become a dangerous practise. Infected men were expected, for the safety of their families, to sleep alone and to avoid cuddling or kissing their children. This made intimacy between husband and wife difficult, and would have been distressing or confusing to children who were used to cuddling their parents. Marina Larsson argues that the departure of a tubercular man from the marriage bed reduced the possibilities for emotional and sexual intimacy'. ${ }^{23}$ The same applies in New Zealand, with the emphasis on separate sleeping quarters - often a tent, if provided by the government - a barrier to intimacy for many couples. This is shown through Government communications on the inspection of shelters used by service patients. The Government stated that 'The

\footnotetext{
${ }^{21} Q M, 10$ June 1922, p.31.

22 'Consumption', New Zealand Department of Health, Eph-C-HEALTH-NZDH-1929-01, available at ATL.

${ }^{23}$ Larsson, Shattered Anzacs, p.187.
} 
majority of patients are therefore issued with a special tent, constructed on $\mathrm{Mr}$ Blackmore's design'. ${ }^{24}$ This meant separation for most TB men from their partners. It is clear some couples or families were breaking the rules imposed by the medical department, despite being told that doing so would risk their health. Instructions for the inspections of all shelters, including verandas and standalone shelters, specified that 'It sometimes happens that more persons than the patient occupy these shelters both by night, and day. This is considered an improper use of the shelter, as only the patient is supposed to occupy it at any rate, by night. ${ }^{25}$ In this case the need for intimacy and a sense of normality prevailed among those who flouted the rules and recommendations for shelters.

Tuberculosis had wide ranging effects on families that sometimes could be tragic, throwing families into disarray. Such effects on families from tuberculosis are seen when reading a report on tubercular cases in Dunedin. One example is the case of a woman aged 35 years, who undertook 6 months treatment in the Palmerston Sanatorium. ${ }^{26}$ When visited in 1926 , it was recorded that her husband, a returned soldier, had passed away two years previously from tuberculosis himself. ${ }^{27}$ It is likely that she contracted the disease from him. However, her children, fortunately, were not infected, and it was stated that the family reported frequently to the doctor and that their home conditions were very good. ${ }^{28}$ The circumstances of this family are both tragic and undoubtedly difficult, with the husband dead and the mother struggling

\footnotetext{
${ }^{24}$ Memorandum for Director General of Health, 18 July 1921, in Shelters for TB Cases 1919-1920, SS 10 S86 1, Archives New Zealand, Wellington.

${ }^{25}$ Memorandum for Director General of Health, $18^{\text {th }}$ July 1921, SS 10 S86 1, Archives New Zealand, Wellington.

${ }^{26}$ Report on Tubercular Cases from 1 January - 31 October, 1926, in Diseases - Tuberculosis - Dunedin 1925-1926, H1 131/3/112, Archives New Zealand, Wellington.

${ }^{27}$ Report on Tubercular Cases from 1 January - 31 October, 1926, H1 131/3/112, Archives New Zealand, Wellington.

${ }^{28}$ Report on Tubercular Cases from 1 January - 31 October, 1926, H1 131/3/112, Archives New Zealand, Wellington.
} 
with illness herself while trying to look after her two children and manage financially. The circumstances of this mother raise questions over who took care of the children while she was away for six months, and the effects of this, and the death of their father, on the children. Watching their mother struggle with the same illness that had killed their father must have been upsetting. Furthermore, for the woman affected, the death of her returned soldier husband in 1924 after he had survived the war would have been heartbreaking for her. This, along with having to leave her children for 6 months, shows the separation TB could cause within a family. The fact that she frequently took these children to be examined by the doctor suggests that she greatly feared the infection of her children.

Another case was of a 31 year old returned man who was gassed during the war, and was in treatment at Palmerston sanatorium for TB in $1926 .{ }^{29}$ This man was previously an office clerk, and was married with three small children, who were all recommended to be examined. In this case, the loss of his income while in sanatorium treatment would have had an impact on the family, even if they were receiving a pension for his illness. His removal from his home would have created extra stress for his wife, left to take care of the children, and there was also the possibility that TB had been passed on to his family. There was also the ongoing worry that he would not recover from his illness and of his employment prospects on return - his previous employers may have been reluctant to take him back on account of public fears of tuberculosis and its spread. The enclosed space of an office may not have been recommended as a good working environment after the open air treatment he would have received at the sanatorium. Again, TB had separated a family, and cast its future

\footnotetext{
${ }^{29}$ Report on Tubercular Cases from 1 January - 31 October, 1926, H1 131/3/112, Archives New Zealand, Wellington.
} 
in doubt. These two examples are likely reflected in the experiences of many returned men who had tuberculosis. Their lives became marred by separation, uncertainty, and fears of infecting others. Financial worries added to this stress, with job prospects diminished for those who were very ill or who could no longer take up their previous occupations. For some, TB led to death, which led to further complications for families, both financially and emotionally.

Changes in lifestyle, including job, were often very significant in TB sufferers' lives. James Miller, the only returned soldier who was interviewed for the Alexander Turnbull Library's oral history collection to have TB, recalled being told that he could no longer work in his clerical job at the Masterton Post Office, stating that the doctor 'told me that I was either get out or go under...if I stopped in a sedentary position, I would die of chest trouble. You know, sitting down all those years' ${ }^{30}$ He heeded this advice, which led to him leaving Masterton and taking up a settlement farm in Taumaranui, which Miller eventually left after his house burnt down. ${ }^{31}$ He remembered 'We were on this farm and my kiddie came in, and he says, Dad, my room is too hot, and I got out of bed and walked into the kitchen and the ceiling fell in. So that was enough for me. I got out. We never saved a damn thing. ${ }^{32}$ For Miller, his inability to stay in his clerical job eventually led him to moving to the farm where he lost everything in a house fire. However, it appears that this change of occupation saved his life - Miller was in his eighties when interviewed. He also did not pass on his illness to family members. Miller had to completely change his occupation, from a desk job to farming, and move his family to another town after being settled in Masterton. Losing everything after this was a cruel blow.

\footnotetext{
${ }^{30}$ Miller, OHC-002700.

${ }^{31}$ Miller, OHC-002700.

${ }^{32}$ Miller, OHC-002700.
} 
Boyack and Tolerton assert that "In the 1920s "consumptives" were still treated as social pariahs', and evidence of this does appear in the historical record. ${ }^{33}$ Public fear of tuberculosis led to demands for compulsory treatment and segregation of tubercular soldiers in 1922 by none other than the RSA itself. This call for segregation included those men who had completed sanatorium treatment who were considered as a 'grave menace to others' - presumably, those who the RSA felt were not taking proper precautions. ${ }^{34}$ However the Deputy Director General of Health, Joseph Frengley, disagreed with this, stating that 'this is a matter which has not been attempted in any civilized country....Segregation would be cruel without being necessary for with the simplest precautions consumption is a disease which is not readily transmitted to others. ${ }^{, 35}$ Here Frengley criticised the RSA for suggesting a move which, in his opinion, would go against the civilised nature of New Zealand. Furthermore, he suggested that the dangers of TB were grossly overstated, pointing out that hygiene measures could prevent the spread of the disease - despite public opinion to the opposite. It appears that medical knowledge of TB at this time was not reported coherently or consistently to the New Zealand public, if it had indeed been discovered that TB was not as contagious as people believed. An emphasis on hygiene and avoiding the transmission of germs often arose in literature on TB and disease in the public sphere. ${ }^{36}$ Given the lack of knowledge about germs at this time, the fear felt over the transmission of these diseases is understandable. Frengley pointed out that

\footnotetext{
${ }^{33}$ Boyack and Tolerton, In The Shadow of War, Auckland, 1990, p.251.

${ }^{34}$ Excerpt from letter from General Secretary, New Zealand RSA, Wellington, to the Hon. Minister of Defence, 27 June 1922, in Diseases - Tuberculosis - Compulsory Treatment and Segregation, H1 $131 / 3 / 68$, Archives New Zealand, Wellington.

${ }^{35}$ Memorandum to the Minister of Health, 26 July 1922, in Diseases - Tuberculosis - Compulsory Treatment and Segregation, H1 131/3/68, Archives New Zealand, Wellington.

${ }^{36}$ For example: Evening Post, 25 November 1922, p.9, contains a discussion on the importance of hygiene among workers, in particular ideas such as sleeping with windows open, open air exercise, and washing hands frequently. This article alleges that most people do not practise this.
} 
those with venereal disease, which he stated was 'more communicable' were permitted to go free, and argued that the segregation of notified TB sufferers, who had undergone treatment and knew which measures to take to prevent the spread of infection, would not be targeting the problem in the correct manner. ${ }^{37}$ Frengley stated that those who were not aware of their condition, and therefore were not taking any precautions to stop the spread of disease are a greater risk to society. ${ }^{38}$ The overall tone of Frengley's response suggests that he felt segregation of any group of society was inhumane. The RSA's demand however shows the fear that surrounded TB and its communicability; so much so that it was suggested that sufferers who were seen not to be taking enough care to protect others should be excluded from society. It also shows that public perceptions of TB were of its highly contagious nature, potentially due to over zealous public announcements by Government authorities. This led to some ostracism for TB sufferers.

Train travel for those being treated at sanatoriums was also an issue, and further exposed public fears of TB and those who carried it. For those patients wanting to travel home at Christmas or on leave, or for those leaving the sanatorium for home, public transport was a popular means of doing so. However, this raised questions over the safety of the public, particularly when those with the disease were in the 'active' phase, and therefore were still considered a danger to others. The Defence Department noted that the public view was 'every case coming from a Sanatorium

\footnotetext{
${ }^{37}$ Memorandum to the Minister of Health, 26 July 1922, H1 131/3/68, Archives New Zealand, Wellington.

${ }^{38}$ Memorandum to the Minister of Health, 26 July 1922, H1 131/3/68, Archives New Zealand, Wellington.
} 
constitutes...a danger' ${ }^{39}$ However the Director General of Health stated that the public's fears were unfounded, opining that

Consumption is now known to be not nearly so infectious as the public imagine....It requires prolonged contact with the infection and a high susceptibility or a lowered state of health to cause infection. The vast majority of consumptives...are not a menace to others when travelling in public conveyances. ${ }^{40}$

It was, however, agreed that 'open and advanced cases of the disease' were a risk to the public, and that in these cases, it was necessary for arrangements to be made for these men to travel separately, and for any blankets used to be disinfected, along with any areas that the men were in. ${ }^{41}$ The fact that public fears were addressed and dismissed by two separate officials shows that it was commonly acknowledged that there was a fear and horror of TB among the general public, and that this fear was often out of proportion to the risk that TB posed. However, messages to the public, such as the poster referenced earlier in this chapter, did nothing to quell fears of the transmission of TB. The instructions to avoid personal contact spelt out the communicable nature of the disease, and its incurable nature and high fatality rate led the public to become extremely fearful of those who had the disease. This, unfortunately, led to a stigma among sufferers, and limited opportunities for those who suffered from TB, even if they were no longer any danger to others.

Gaining a pension for TB could be wrought with difficulties, and compounded stress on sufferers who were struggling to find work or could not work. Questions

\footnotetext{
${ }^{39}$ Memorandum for the Director General of Health from G Maclean, Medical Superintendent, 12 February 1925, in Diseases - Tuberculosis - Special Boat and Train Accommodation, H1 131/3/34, Archives New Zealand, Wellington.

${ }^{40}$ Letter to the Secretary Wallace and Fiord Hospital Board, 31 March, 1925, in Diseases - Tuberculosis Special Boat and Train Accommodation, H1 131/3/34, Archives New Zealand, Wellington.

${ }^{41}$ Letter to the Secretary Wallace and Fiord Hospital Board, 31 March, 1925, H1 131/3/34, Archives New Zealand, Wellington.
} 
arose over the validity of claims, particularly whether or not TB was contracted while at the front, or later on. TB sufferers did not show symptoms immediately; the infection has the ability to lie dormant in those who have contracted it, therefore many men who contracted TB at the front could find themselves showing symptoms some time later. Despite the slow onset nature of TB, it appears that there were issues for those seeking pensions when their illness had developed after a reasonable period at home. The Quick March contained an article from a specialist who admonished the Health Department for stating that it was "remarkable that so many soldiers develop consumption a year of so after returning from the front."' The specialist rejected this, stating 'No statement could be more absurd or misleading. It is obvious that these men had consumption before they returned' ${ }^{42} \mathrm{He}$ argued that 'the disease is so insidious in its onset that the patient might not seek advice till he has been ill for a year or more. ${ }^{43}$ This delay in diagnosis and treatment meant that claims that the disease had not been contracted from war service were easier to justify. The government was accused of being unsympathetic to TB cases, despite assertions that it gave 'the benefit of the doubt' to TB men - an MP, W.A. Veitch, attacked the Minister of Defence in 1922, The Hon. Sir H. Rhodes, stating that there were cases that had come to his attention in which soldiers were not given the benefit of the doubt, and that there were many cases of extreme hardship occurring due to this. ${ }^{44}$ Interviewee James Miller described how his pension was cut off:

...I was three months on sick leave in 1919, three months in '20, and then another three months and then they decided l'd get no more sick pay. So my sister wrote to...Sykes, a member for Wairarapa, and told him that Massey had made a statement in the house that no soldier would be penalised for war

\footnotetext{
${ }^{42} Q M, 10^{\text {th }}$ May 1921, p.23.

${ }^{43} Q M, 10^{\text {th }}$ May 1921, p.23.

${ }^{44}$ EP, 9 September 1922, p.7.
} 
service. So word came back that in future all my sick pay related to my chest would be on full pay. ${ }^{45}$

For Miller, the promise was kept, with him stating at the time of the interview that 'I'm still on the bloody pension'. ${ }^{46}$ However, it had taken the action of the MP for Wairarapa, Mr G.R. Sykes, to ensure that he was still receiving this. This undoubtedly caused unwanted financial stress, especially as Miller was married at this time, and the fact that his sister intervened on his behalf and contacted Mr Sykes shows that she was concerned for him and his wife. The case of another soldier, who had originally been incorrectly diagnosed with malaria, was brought to the attention of the Defence Department by Dr Lyth of Dunedin hospital. He stated that the patient, who was in Pleasant Valley Sanatorium, was told that his tuberculosis was not caused by active service, whereas $\mathrm{Dr}$ Lyth disagreed. ${ }^{47}$ Fortunately for this patient, the Defence Department agreed with Dr Lyth. In these cases, the intervention of doctors and MPs on their behalf was needed before they were able to receive pensions that they were entitled to. Not all soldiers would have attracted the attention of doctors, or may not have felt that they could contact their MPs over such matters. It is also likely that some authority figures were uninterested or felt unable to advocate for some men. For these men, the costs of treatment could lead to financial ruin. Disabled returnees sometimes had to sell their belongings or remortgage their homes to meet the costs of treatment, causing financial and emotional stress for themselves and their families. ${ }^{48}$ Tubercular men were among those who faced this reality, and for some this

\footnotetext{
${ }^{45}$ Miller, OHC-002607.

${ }^{46}$ Miller, OHC-002700.

${ }^{47}$ Memo for A.D.M.S., Dunedin, from Sgd. C.E.W. Lyth, 15 February 1921, in Medical - Consumption Returned Soldiers - General File, AD1 49/383/2, Archives New Zealand, Wellington.

${ }^{48}$ Peter J. Boston, "The Bacillus of Work": Masculinity and the Rehabilitation of Disabled Soldiers in Dunedin 1919-1939', BA Hons Thesis, Otago University, 1997, pp.41-42.
} 
undoubtedly led to dire financial problems and even marriage breakups. ${ }^{49}$ Inability to gain a pension had many flow on effects for a returned serviceman.

Job prospects for TB men were often bleak, and it has been argued that men were pushed into jobs which were very unsuitable immediately after sanatorium stays. ${ }^{50}$ One newspaper article stated that 'To successfully repatriate the "T.B" soldier he must be his own employer, and the whole solution to the difficulty is to place men on the land ${ }^{\prime 51}$ The ideal of rural life - as a peaceful and healthful existence - extended itself to TB men through schemes to place them on the land. As TB men were recommended to undertake light work only, finding employment could be difficult, especially when no such work was available. Boyack and Tolerton present cases in which men were encouraged to work, had pensions cut, and ended up in jobs which worsened their conditions. Their examples include 'a man who had been almost unable to walk when he was discharged but had been told to go to work....A couple of months later he relapsed, was readmitted to as sanatorium and died ${ }^{\prime 52}$ Another man took up furniture moving and gave up on his first day because it caused him to spit blood, and other men borrowed to own businesses and farms but found they were physically unable to do the work. ${ }^{53}$ This shows ignorance on the part of the Defence Department and doctors, and a clear belief that physical work was a cure-all for these men. Attempts were made to retrain TB men; a training farm set up at Tauherenikau for TB men had, by 1921, trained 124 men in market gardening, bee culture, and poultry farming. ${ }^{54}$ TB men did go into farming: by September 1921, 33 men had been

\footnotetext{
${ }^{49}$ Boston, "'The Bacillus of Work"', p.42.

${ }^{50}$ Boyack and Tolerton, In The Shadow of War, p.251.

${ }^{51}$ EP, 26 May 1920, p.4.

${ }^{52}$ Boyack and Tolerton, In The Shadow of War, p.251.

53 Boyack and Tolerton, In The Shadow of War, pp.251-252.

${ }^{54}$ EP, 20 July 1921, p.8.
} 
placed on soldier settlements by the Lands Department. ${ }^{55}$ Settlements for TB men were procured at Hornby and on Mount Pleasant in Canterbury for the purposes of bee keeping, poultry and market gardening. ${ }^{56}$ Farming was seen as an ideal occupation for TB men, due to its outdoor nature. However, advice on the suitable nature of outdoor work for TBs was conflicting. An article in the RSA Quick March advised TB men not to be 'led astray by the advice that an arrested case of tuberculosis should have an outside job....they require too much manual labour'. ${ }^{57}$ It also stated that indoor jobs were suitable for TB men, but that 'Dusty and insanitary places must be avoided but these are the exception rather than the rule'. ${ }^{58}$ It also published the results of a New York study that concluded TB patients who worked indoors had better health outcomes than those who worked outdoors. ${ }^{59}$ The RSA's recognition of this paradox came later in April 1921, where at the end of an article about the success of some TB settlements in Quick March, it was explained that physical work must be undertaken gently while in treatment, and that

There is a common fallacy that fresh air is the chief thing in selecting an occupation....The ideal is not - as commonly supposed - to place men on the land. In the majority of cases the land is not a suitable occupation for the work...is too heavy. ${ }^{60}$

The focus on light farming work while in treatment, with small scale farming promoted for TB men, was the reason that it was deemed suitable for some men. The levels of physical exertion would remain reasonably low, due to the small size of the

\footnotetext{
${ }^{55}$ Memorandum for the Hon. Minister of Defence from D.H. Guthrie, Minister of Lands, 9 September 1921, in Medical - Consumption - Returned Soldiers - General File, AD1 49/383/2, Archives New Zealand, Wellington.

${ }^{56}$ QM, 10 November 1920, p.41, \& 10 December 1920, p.33.

${ }^{57} Q M, 10$ November 1920, p.38.

${ }^{58}$ QM, 10 November 1920, p.38.

${ }^{59} Q M, 10$ February 1921, p.29.

${ }^{60}$ QM, 11 April, 1921, p.37.
} 
farms and the less strenuous nature of the work. This part of the article is interesting in that it puts a caveat on the idea of outdoor farming work for all TB men. This confusion between the suitability of outdoor and indoor work no doubt led to men being told that they could not undertake avenues of work that would have done no harm to their health; some may have resigned from indoor office or factory jobs under incorrect advice. In 1924, the Canterbury RSA asked the government to open up more 'avenues of light employment' for returned TB's, clearly subscribing to the idea that too much physical work was not good for these men. ${ }^{61}$ As late as 1930 , the work question for TB men had not been resolved; the NZRSA Review printed that TB pensioners were struggling to find work due to 'a certain amount of prejudice against taking on men who had been under treatment. Sometimes fellow employees themselves created difficulties with no justification. ${ }^{62}$ Dr Aitken, previously of the Cashmere Sanatorium, was of the opinion that an employment officer could be used to try to break down some of these prejudices in workplaces and make life easier for TB men. Unfortunately, at this time TB men were about to become part of a larger group of unemployed people, and their plight would become more severe. What is clear is that TB men suffered from lack of knowledge about their condition; this led to some of their employment struggles. The shame and stress that their TB status caused undoubtedly put pressure on their families, along with the stress that unemployment caused.

Returned soldiers suffering from TB had difficult lives on return, for a variety of reasons. Their lives became medicalised; if they undertook treatment, they faced separation from their families, and they had to modify their home lives so as not to

\footnotetext{
${ }^{61} E P, 15$ May 1924, p.11.

${ }^{62}$ The N.Z.R.S.A. Review, February 1930, p.15.
} 
spread the disease to others. This could lead to reduced intimacy, and a burden on other family members to nurse the sufferer. It also caused more work providing hygienic surroundings for the TB man and his family. Pension and job worries all led to extra financial stress, and the death of a TB soldier could cause both great emotional upset and also great financial difficulty. Public attitudes to TB and its sufferers did little to help. Fears of the spread of disease led to ostracism for sufferers, some of which, particularly in terms of employment, was ongoing and led to men being unable to secure jobs. There also appeared to be some confusion over what was best for returned men after treatment; small scale farming schemes were introduced for men, but there was conflicting advice over the safety of indoor work, particularly in sedentary jobs. James Miller was told to go farming as his sedentary job would do him harm in the long run, yet the Quick March printed advice stating that sedentary jobs were often beneficial to TB men who could not be over-exerted, and that farming was unsuitable due to the amount of exertion required. This confusion no doubt did not help the status of unemployed TB men, some of whom may have needlessly left jobs because they were told they were dangerous. The confusion surrounding the best way to treat TB, and indeed how to diagnose TB, caused hardship for many. Pension boards would not give pensions to all returned men who were diagnosed with $T B$, despite the disease's often latent first stage of infection. Returned TB's in particular were singled out for overstating symptoms to continue their pensions, largely due to the RSA's active role in advocating for returned TB men's pensions. All of these circumstances show that the TB man's post-war life could be fraught with difficulties; lifestyle changes, stresses, and money worries, all of which had a direct effect on family life. 


\section{Conclusion}

I've been able to recover....I adapted myself to ordinary life again....I've had a very happy life since. So I can't complain....It's unfortunate that it happened, the war anyhow, that's all that I can say. ${ }^{1}$

- Wilfred Davies, 1988.

It is safe to say that every man who was away from his home during the Great War had expectations of what he wanted on return. This could have been as simple as wishing to return to a lifestyle the same as before the war, others may have decided to make some major changes in their lives. Whatever men were thinking of, surviving records show many wanted some kind of security, whether that lay in a job, in marriage, or within their family. New Zealand was a haven to these men who were undergoing difficult experiences and long separations. It held the happy experiences of their past, the hopes for their future, and furthermore, it was a land of peace and plenty. While home comforts were dreamed of by men at the front, most cited their personal, emotional connections as the most important part of their return - the thoughts of reuniting with loved ones and lovers. On return, family support was important but evidence indicates employment was of the utmost concern and seen as the key to successful repatriation.

All returned soldiers faced uncertainty on their return from war, and various factors made this more or less severe. The World War I oral history collection shows that many men who returned were, with the help of family, friends and in most cases, regular employment, able to resume their lives with relative ease. Employment was often the key factor in this, with lack of employment delaying men's ability to move on

\footnotetext{
${ }^{1}$ Wilfred Davies, interview by Jane Tolerton and Nicholas Boyack, 4 December 1988, for the World War I Oral History Archive, held in the Oral History Centre, ATL, OHC-002607.
} 
with life. Men without or with low paying jobs were less likely to marry due to social mores dictating that men were breadwinners and women should not work after marriage. Furthermore, unemployment led to a lack of security that undermined men's happiness, particularly when this compromised their ability to provide for a family that they already had. The desperation of men to find jobs is in no place more obvious than the 'Situations Wanted' columns of newspapers of the time, where men laid bare their sometimes dire situations and their willingness to do anything or go anywhere for work. Furthermore, desperation for work led to returnees and their advocates targeting their frustration at women and foreigners, who they believed should not be occupying jobs that returnees could have. Some men found temporary work but this was only a stopgap measure providing little long term security. For those who expected to return to some kind of employment, or expected their jobs to be open for them, unemployment was a large setback and affected men's dreams and plans for the future. The government's response to this unemployment shows some attempts to accommodate returnees, with grants for study and apprenticeships, and the work of the Repatriation Department who placed men in temporary and permanent jobs. However, this work ceased in prematurely 1922 , while many men still faced uncertain futures. By 1929, 5000 returnees were still struggling to obtain or hold on to jobs, making it apparent that the work of the Repatriation Department would have been viable throughout the 1920 s. $^{2}$ The government's other response to soldier unemployment was the soldier settlement programme. Both the uncertainty of employment and dreams of a new life led men to take up the offer of a soldier settlement farm on return. For some men, their farms turned out successfully,

\footnotetext{
${ }^{2}$ Gwen Parsons, "The Many Derelicts of the War'? Great War Veterans and Repatriation in Dunedin and Ashburton, 1918-1928', PhD, 2008, Otago University, pp.106-7.
} 
sometimes with struggles along the way. However, for others, the struggles could be overwhelming and cause great strain that they were not anticipating. This strain came in the form of financial problems and stress from working hard on farms that could be unproductive. Isolation was another problem for some of these men on remote farms, holding them back from a social life or substantial human contact. Settlers often found their circumstances dire and had to ask the government repeatedly for help with their finances, a process which often landed them in worse financial trouble. In the worst cases, some men found the stress affected their mental or physical health, and this could have negative effects on family life. For many, dreams of financial independence and the ability to be self sufficient faded away under these circumstances.

Histories of disabled returned men show that the pensions system did not work well, with pensioners struggling to make ends meet, and some men being unable to retain their pensions long term, despite ongoing health problems. ${ }^{3}$ Disabled returnees faced struggles in terms of finding and retaining employment, particularly if they were no longer able to work in their pre-war profession. This caused financial strains for these men, and could cause strains in their family lives. This thesis has shown that tubercular soldiers also faced ostracism, poverty, and all too often, a shortened life marred by illness. Their families' lives were also affected by their illness in many ways. These are findings that reinforce other studies' conclusions. ${ }^{4}$ Alcoholic men, however, are not obvious in historical records of hospitals or war pensions. Their plight is revealed in other ways - such as in histories of crimes against women, or in mentions

\footnotetext{
${ }^{3}$ Nicholas Boyack and Jane Tolerton, In The Shadow of War, Auckland, 1990, pp.246-7; Elizabeth Walker, "The Living Death': the repatriation experience of New Zealand's wounded Great War servicemen', MA thesis, Victoria University, 2011.

${ }^{4}$ Boyack and Tolerton, In The Shadow of War, pp.251-252; \& Marina Larsson, Shattered Anzacs - Living with the scars of war, Sydney, 2009, pp.189-90.
} 
of the booze culture of the RSA. ${ }^{5}$ Both TB and Alcoholic men became medicalised to some extent after the war, often coming under the care of the state or of families. The circumstances of their need for care were very different, but both groups suffered from wounds, both invisible, that largely resulted from, or were exacerbated by war, and required treatment. While tubercular men received much more public sympathy and advocacy in terms of pensions, both groups suffered from social ostracism; for TB men, this was due to the highly contagious nature of their disease and over-zealous efforts to avoid infection, along with the lack of medical knowledge about TB, or a cure, at the time. Returned soldiers found themselves ostracised and criticised for voting against prohibition, and earned a reputation for imbibing excessively. This fed into highly visible media reporting on antisocial behaviour, which further ostracised returned soldier drinkers. Alcoholic returnees also faced isolation through prohibition and rehabilitation, or eventually brought it on themselves due to their rejection and ill treatment of loved ones. Alcoholic men also had the added difficulty of the drinking culture that pervaded many returned soldier gatherings, and which was fostered by some RSA clubs providing alcohol, seemingly with few restrictions or thoughts for the health of those they served it to. For an alcoholic to stop drinking altogether would have often meant avoiding social events at their local club. Tubercular and alcoholic soldiers are more difficult to find in the historical record than soldiers with other disabilities. Alcoholic men could find it difficult to link their condition to war service, with those who were sent for treatment at Hanmer or Roto Roa the only potential candidates. Tubercular men, in some cases, could link their condition to war service, but this was also difficult, particularly with the delayed onset of the illness. Due to this,

\footnotetext{
${ }^{5}$ Judith Allen, Sex and Secrets - Crimes Involving Australian Women Since 1880, Melbourne, 1990; \& Stephen Clarke, 'Return, Repatriation, Remembrance and the Returned Soldiers' Association 1916-22, in John Crawford \& Ian McGibbon (eds.), New Zealand's Great War, Auckland, 2007, pp.157-180.
} 
it is harder to find the stories of tubercular or alcoholic soldiers in the historical record, and their plight is not discussed in great depth in New Zealand's war historiography. A loss of intimacy, financial worries, and fears for their returned man were all problems that they shared. Marriage problems and separations could occur for some if the strain became too much. Domestic life, for both groups, had its stability undermined by financial or personal, relational factors. The dreams of settled family life were interrupted and often forever undermined.

The findings of this thesis also give a wider understanding to the social attitudes of the 1920s. The public feared returned men becoming idle, useless members of society. The unemployed returnee was an object of anxiety as the public feared the consequences of his idleness such as crime and a financial drain on society. Furthermore, there were anxieties over the illnesses of soldiers that could be spread among general society. Tubercular soldiers were ostracised, had difficulty finding employment, and raised concerns among the public when travelling to and from sanatoria. Intemperate soldiers were seen in the streets causing trouble on return and later in the pages of newspapers having committed crimes; worries proliferated over these men and how they could be rehabilitated, as evidenced in the government's correspondence. This is all as a counterpoint to the ideal of the Anzac hero, the soldiers who at Gallipoli showed 'their strength, their intelligence and death-scorning devotion to duty'. ${ }^{6}$ As men returned from war and Anzac day was marked each year, more rhetoric of the heroic, masculine soldier ensued. ${ }^{7}$ For those soldiers who returned to adverse circumstances and seemingly did not overcome them, such rhetoric must have rung hollow. The returned soldier as an object of pity or scorn

\footnotetext{
${ }^{6}$ Scott Worthy, 'A Debt of Honour: New Zealanders' First Anzac Days', New Zealand Journal of History, Vol.36, No.2, 2002, p.187.

${ }^{7}$ Worthy, 'A Debt of Honour', p.189.
} 
worked against the masculine image of the hero. Antisocial behaviour by returnees was met with disappointment, as this was a let down to those who expected these men to set an example. The proliferation of articles naming and shaming returnees for various crimes and misdeeds fed into this. Returned soldiers did not, and could not, live up to the standards set for them in terms of heroic martial identities. They also could not always fulfil their masculine identities, with some men unable to work, and therefore unable to fulfil the breadwinner ideal so important in society in the 1920s. Society's expectations for gender roles and for the Anzac hero raised the stakes for men when they returned home and attempted reintegration, surely placing more psychological stress on their shoulders.

Underlying all of the experiences described in this thesis is a great deal of uncertainty for these men. The war caused their lives to be put on hold. Some men could not marry until they found employment or until they were financially secure. For those men who had families, financial stress and illness could take a great toll on security and intimacy. Marriages became strained under such conditions, and some did not survive. Men could find themselves in very different situations than they anticipated while dreaming of the future at the front, jobless, ill or alone. Sadly, for some, their lives were forever marred by the spectre of war and what their absence from home cost them. Broken dreams and unhappiness were reality for these men whose ability to reintegrate and readjust to civilian life was affected negatively. For many men, this process was slowed down by months or years depending on their circumstances. Having to wait to marry or to start one's career was frustrating for men who had already been away from home for so long. Clearly many of these men managed to eventually move on from these experiences; the unemployed found jobs 
and established themselves financially, some soldier farmers did succeed, while others walked off their farms and into other occupations. For others, particularly the ill of mind and body, the war continued to affect their lives throughout the decade following the cessation of hostilities. The prospect for tuberculosis sufferers was grim, with treatments in the 1920 s unable to guarantee a cure. Some men, despite treatment, found that their health declined steadily over the years. Others regained their health but still faced struggles in terms of employment. Alcoholic men also faced treatment that was not certain to work. Some lost their families or committed crimes under the influence of alcohol. For both tubercular and alcoholic men, uncertainty was part of their lives and the lives of the loved ones who took care of them. They did not know when or if their health would improve, and for those not receiving pensions, money was a particular problem. The end of the 1920s did not spell the end of problems for these men. The uncertainties of life during the Depression in the 1930s no doubt affected this group of men as well, and this is a study that is yet to be undertaken. 


\section{Bibliography}

\section{Primary Sources}

Newspapers

\section{Ashburton Guardian}

'Offended Diggers', Ashburton Guardian, Issue 9619, 28 May 1919, p.7.

\section{Colonist}

'A Poor Response', Colonist, Issue 15058, 29 April 1919, p.5.

'Returned Soldiers. An Important Communication', Colonist, Issue 15254, 16 Dec 1919, p.7.

\section{Evening Post}

'An Unhappy Home', Evening Post, Issue 21, 24 January 1919, p.8.

'Canterbury R.S.A. Resolutions Passed at Annual Conference', Evening Post, Issue 114, 15 May 1924, p.11.

'Drunk in a Car', Evening Post, Issue 98, 26 April 1926, p.10.

'Ex-Soldiers' Claims - The Government's Sympathy Questioned', Evening Post, 9 September 1922, p.7.

'Returnees - And Society', Evening Post, Vol. 95, Issue 116, 16 May 1918, p.8.

'Situations Wanted', Evening Post, Issue 42, 18 August 1920, p.1

'Situations Wanted', Evening Post, Issue 85, 7 October 1920, p.3.

'Situations Wanted', Evening Post, Issue 11, 13 January 1921, p.1.

'Situations Wanted', Evening Post, Issue 38, 13 August 1921, p.1.

'Situations Wanted', Evening Post, Issue 115, 11 November 1921, p.1

'Situations Wanted', Evening Post, Issue 49, 28 February, 1922, p.1

'Situations Wanted', Evening Post, Issue 61, 14 March 1922, p.1.

'Situations Wanted', Evening Post, Issue 97, 27 April 1922, p.1.

'Situations Wanted', Evening Post, Issue 23, 27 January 1923, p.1. 
'Situations Wanted', Evening Post, Issue 37, 13 February 1923, p.1.

'Soldier's Protest - First offender for drunkenness imprisoned', Evening Post, Issue 7, 9 January 1926, p.19.

'T.B. and Chest Cases', Evening Post, Issue 124, 26 May 1920, p.4.

'T.B. Soldiers, Their Care and Training', Evening Post, Issue 20, 20 July 1921, p.8.

'The Wastage of Life', Evening Post, Issue 127, 25 November 1922, p.9.

'Women's Convention', Evening Post, Issue 86, 9 October 1919, p.5.

\section{Hawera and Normanby Star}

'Prohibition Rally at the Grand', Hawera \& Normanby Star, 15 December 1919, p.5.

'Riotous Behaviour. Scenes in Wellington', Hawera \& Normanby Star, 2 July 1918, p.8.

\section{Marlborough Express}

'Returned Soldiers. Regrettable Scene at ANZAC Dinner', Marlborough Express, Issue 102, 4 May 1918, p.2.

\section{NZ Truth}

'The Clifton Gift', NZ Truth, Issue 680, 29 June 1918, p.6.

'Cutting the Losses', NZ Truth, Issue 1207, 17 January 1929, p.4.

'Ex-Champ's Collapse', NZ Truth, Issue 984, 4 October 1924, p.5.

'God's Own Country', NZ Truth, Issue 852, 18 March 1922, p.1.

'The Great White Scourge', NZ Truth, Issue 999, 17 January 1925, p.5.

'Hard Labour for “Diggers”', NZ Truth, Issue 741, 30 August 1919, p.1.

'Lure of the Land', NZ Truth, Issue 925, 18 August 1923, p.7.

'Morally Weak A libel on our soldier lads', NZ Truth, Issue 710, 25 January 1919, p.5.

'No Digger Need Apply', NZ Truth, Issue 820, 30 July 1921, p.9.

'Pawned Her Wedding Ring', NZ Truth, Issue 1101, 6 January 1927, p.7.

‘Returned Soldier Problem', NZ Truth, 13 April 1918, p.6. 
'Re-valued Soldier Farms Former Swamp Lands', NZ Truth, Issue 973, 19 July 1924, p.5.

'Soldiers' Settlements', NZ Truth, Issue 715, 1 March 1919, p.1.

'The Soldiers' Vote - The Why and Wherefore', NZ Truth, Issue 726, 17 May 1919, p.4.

'Sorrows of Soldiers', NZ Truth, Issue 937, 10 November 1923, p.6.

'The Twin Whirlpools', NZ Truth, Issue 1008, 21 March 1925, p.1

'The Yellow Peril', NZ Truth, Issue 857, 22 April 1922, p.3.

Poverty Bay Herald

'Liquor on Trains', Poverty Bay Herald, Issue 14875, 1 April 1919, p.5.

\section{Periodicals}

\section{RSA Review}

'Lost all Drink Craving', The N.Z.R.S.A Review, Vol.1, No.3, February 1925, p.12.

'T.B. Patients', The N.Z.R.S.A. Review, February 1930, p.15.

\section{RSA Quick March}

'Advice for T.B.'s.', Quick March, 10 November 1920, p.38.

'A Budget for T.B.'s', Quick March, 11 April, 1921, p.37.

'A Budget for T.B.'s', Quick March, 10 February 1921, p.29.

'Christchurch - Local Affairs', Quick March, 10 June, 1919, p.56.

'Curing Consumption', Quick March, 10 June 1922, p.31.

'Drink Habit Cured', Quick March, 10 August 1920, p.31.

'Employment for Soldiers', Quick March, 10 June 1919, p.74.

'Farms and Homes for Discharged Soldiers', Quick March, 10 May 1919, p.69.

'For T.B. Men', Quick March, 10 December 1920, p.33.

'The Government and Conference', Quick March, 1 December 1919, p.89.

'Land - RSA Draft Proposals', Quick March, 10 September 1919, p.52.

'Land', Quick March, 10 August, 1922, p.31. 
'Lost all drink Craving', Quick March, 10 June 1920, p.53.

'Men at Roto-Roa', Quick March, 11 October, 1920, p.47.

'Pumice for Diggers', Quick March, 10 May 1919, p.32.

'Repatriation', Quick March, 10 July 1919, p.42.

'Repatriation', Quick March, 10 July 1919, p.53.

'Repatriation and Apprentices', Quick March, 10 July 1919, p.57.

'Settlement for T.B. Men', Quick March, 10 November 1920, p.41.

'Soldier Alcoholics', Quick March, 10 March 1920, p.69.

'Soldier Settlement', Quick March, 10 March 1920, p.35.

'T.B. Notes', Quick March, 10 May 1921, p.23.

'Timaru Disturbance', Quick March, 10 May 1920, p.67.

V.C.F, 'Women and Home. What of the future?', Quick March, 10 June 1919, p.78.

'Visit to Roto Roa', Quick March, 10 September, 1920, p.69.

Appendices to the Journal of the House of Representatives

New Zealand Government, Appendix to the Journal of the House of Representatives, 1918.

New Zealand Government, Appendix to the Journal of the House of Representatives, 1919.

New Zealand Government, Appendix to the Journal of the House of Representatives, 1920.

\section{Government Statistics}

New Zealand Government, Vital Statistics, 1924.

New Zealand Government, Vital Statistics, 1925.

World War One Oral History Archive

Bisman, James, interview by Jane Tolerton and Nicholas Boyack, 4 December 1988, for the World War I Oral History Archive, held in the Oral History Centre, Alexander Turnbull Library, OHInt-0006/10. 
Davies, Wilfred interview by Jane Tolerton and Nicholas Boyack, 4 December 1988, for the World War I Oral History Archive, held in the Oral History Centre, Alexander Turnbull Library OHInt-0006/21.

Dill, Frederick interview by Jane Tolerton and Nicholas Boyack, 29 September 1988, for the World War I Oral History Archive, held in the Oral History Centre, Alexander Turnbull Library, OHInt-0006/23.

Emmins, Arthur, interview by Jane Tolerton and Nicholas Boyack, 21 September 1988, for the World War I Oral History Archive, held in the Oral History Centre, Alexander Turnbull Library, OHInt-0006/26.

Fougere, Francis Jude, interview by Jane Tolerton and Nicholas Boyack, 8 November 1989, World War I Oral History Archive, held in the Oral History Centre, Alexander Turnbull Library, OHInt-0006/27.

Gainfort, Benjamin, interview by Jane Tolerton and Nicholas Boyack, 1 November 1988, World War I Oral History Archive, held in the Oral History Centre, Alexander Turnbull Library, OHInt-0006/28.

Gordon, Colin, interview by Jane Tolerton and Nicholas Boyack, 12 September 1988, World War I Oral History Archive, held in the Oral History Centre, Alexander Turnbull Library, OHInt-0006/31.

Gregor, Jack, interview by Jane Tolerton and Nicholas Boyack, 6 August 1988, World War I Oral History Archive, held in the Oral History Centre, Alexander Turnbull Library, OHInt-0006/32.

Harris, Les, interview by Jane Tolerton and Nicholas Boyack, 7 August 1988, World War I Oral History Archive, held in the Oral History Centre, Alexander Turnbull Library, OHInt-0006/34.

Hartley, Charles, interview by Jane Tolerton and Nicholas Boyack, 22 September 1988, World War I Oral History Archive, held in the Oral History Centre, Alexander Turnbull Library, OHInt-0006/35.

Jamieson, Frank, interview by Jane Tolerton and Nicholas Boyack, 4 December 1988, World War I Oral History Archive, held in the Oral History Centre, Alexander Turnbull Library, OHInt-0006/42.

Miller, James, interview by Jane Tolerton and Nicholas Boyack, 14 May 1988, World War I Oral History Archive, held in the Oral History Centre, Alexander Turnbull Library, OHInt-0006/55. 


\section{Government Files - Archives New Zealand}

Discharged Soldiers Settlement - C H Inwood, AAMB RLDSS 27/1, Archives New Zealand, Wellington

Discharged Soldiers Settlement - Daniel Hurley, AAMB RLDSS 10/1, Archives New Zealand, Wellington.

Discharged Soldiers Settlement - Daniel James and William John Dellow, 1920-1922, AAMB RLDSS 24/1, Archives New Zealand, Wellington.

Diseases - Tuberculosis - Compulsory Treatment and Segregation, H1 131/3/68, Archives New Zealand, Wellington.

Diseases - Tuberculosis - Dunedin - 1925-1926, H1 131/3/112, Archives New Zealand, Wellington.

Diseases - Tuberculosis - Special Boat and Train Accommodation, H1 131/3/34, Archives New Zealand, Wellington.

Medical - Alcoholism among Returned Soldiers - Treatment - 1918-1921, AD1 49/791, Archives New Zealand, Wellington.

Medical - Complaints - Cashmere Sanatorium, AD1 49/695/11, Archives New Zealand, Wellington.

Medical - Consumption and Returned Soldiers - Correspondence - Auckland Local Bodies and Societies 1919, AD 1 49/383/3, Archives New Zealand, Wellington.

Medical - Consumption Returned Soldiers General File, AD1 49/383/2, Archives New Zealand, Wellington.

Personnel - Discipline - Cashmere Sanatorium Christchurch, AD1 24/73/240, Archives New Zealand, Wellington.

Public Service Employment of Returned Soldiers, April 1919-August 1919, AD 87 VA/103/30, Archives New Zealand, Wellington.

Returned Soldiers: Re Medical Examination on Entering Public Service: 1917-1919, AATJ GS 5/8/2 11, Archives New Zealand, Wellington.

Shelters for TB Cases 1919-1920, SS 10 S86/1, Archives New Zealand, Wellington.

Tuberculosis - Control and Treatment - 1919-1955, H1 246/41, Archives New Zealand, Wellington. 


\section{Ephemera - Alexander Turnbull Library}

'Consumption', New Zealand Department of Health, Eph-C-HEALTH-NZDH-1929-01, Alexander Turnbull Library, Wellington.

\section{Unpublished Diaries and Letters - Alexander Turnbull Library}

Anstice Family, Herbert Anstice - Correspondence, 1918-1919, MS-Papers-5164-08, Alexander Turnbull Library, Wellington.

Anstice Family, Letters from May Anstice to her husband, Bert, 1918, MS-Papers-553504, Alexander Turnbull Library, Wellington.

Anstice Family, Letters from May Anstice to her husband, Bert, 1918, MS-Papers-553505, Alexander Turnbull Library, Wellington.

Cleland, Hugh, Letters to Lily, Jul 1917-Mar 1919, MS-Papers-2340, Alexander Turnbull Library, Wellington.

Crowley Family, Letters, 1917-1919 MS-Papers-4131, Alexander Turnbull Library, Wellington.

Free Family, Letters, 1914-1919, MS-Papers-4387, Alexander Turnbull Library, Wellington.

Glass, Henry, Letters, 1917-1918, MS-Papers-8983, Alexander Turnbull Library, Wellington.

Inglis, Lindsay Merritt (Major General), Papers, 1894-1966, MS-Papers-0421, Alexander Turnbull Library, Wellington.

Jones, Albert, Papers, 1914-1919, Micro-MS-0592, Alexander Turnbull Library, Wellington.

Lynch, Thomas, 1917-1918 MS-Papers-10272, Letters home during World War One, Alexander Turnbull Library, Wellington.

Mowat, Roy Letters, 1914-1918, MS-Papers-7496-06, Alexander Turnbull Library, Wellington.

Pounteney, Arthur, Letters, 1915-1918, MS-Papers-6712, Alexander Turnbull Library, Wellington.

Stokes, Bertram Oliver, Papers relating to service in World War One, 1896-1994, MSPapers-4683, Alexander Turnbull Library, Wellington. 


\section{Published Diaries and Letters}

Howden, Peter, Letters, in Jock Phillips, Nicholas Boyack and E.P. Malone (eds.), The Great Adventure, Wellington, 1988, pp.157-194.

Smith, Wilfred Collinson, Letters, in Jock Phillips, Nicholas Boyack and E.P. Malone (eds.), The Great Adventure, Wellington, 1988, pp.195-228.

Wilton, Len, Letters to IIma McLachlan, in Beth Sutherland (ed.), My Dear Chick - A New Zealand Love Story 1911-1948, Masterton, 2008, pp. 45-230.

\section{Databases}

Roberts, Evan, Heights and Weights Database, Victoria University, 2010.

\section{Secondary Sources}

\section{Books}

Allen, Judith, Sex and Secrets - Crimes Involving Australian Women Since 1880, Melbourne, 1990.

Boyack, Nicholas, Behind the lines : the lives of New Zealand soldiers in the First World War, Wellington, 1989.

Boyack, Nicholas and Tolerton, Jane, In the Shadow of War, Auckland, 1990.

Brookes, Barbara, Cooper, Annabel, \& Law, Robin, Sites of Gender: Women, Men and Modernity, 1890-1939, Auckland, 2003.

Bryder, Linda, Below the Magic Mountain, New York, 1998.

Commachio, Cynthia, The Infinite Bonds of Family: Domesticity in Canada, 1850-1940, Toronto, 1999.

Enticott, T.O., Up The Hill - Cashmere Sanatorium and Coronation Hospital 1910-1991, Christchurch, 1993.

Eldred-Grigg, Stevan, The Great Wrong War, Auckland, 2010.

Garton, Stephen, The Cost of War - Australians Return, Melbourne, 1996.

Harper, Glyn, Dark journey, Auckland, 2007.

Harper, Glyn, Letters from the Battlefield: New Zealand Soldiers Write Home, 19141918, Auckland, 2002.

Harper, Glyn, Letters from Gallipoli: New Zealand soldiers write home, Auckland, 2011. 
Harper, Glyn, Massacre at Passchendaele: the New Zealand story, Auckland, 2000.

Harper, Glyn, Spring offensive: New Zealand and the second Battle of the Somme, Auckland, 2003.

Heather, Nick \& Robertson, Ian, Problem Drinking, 3ed., Oxford, 1997.

Hickey, Maureen, \& Olssen, Erik, Class and Occupation: The New Zealand Reality, Dunedin, 2005.

Kinloch, Terry, Echoes of Gallipoli : in the words of New Zealand's Mounted Riflemen, Auckland, 2005.

Lake, Marilyn, The Limits of Hope: Soldier Settlement in Victoria 1915-1938, Melbourne, 1987.

Larsson, Marina, Shattered Anzacs - Living with the scars of war, Sydney, 2009.

Lummis, Trevor, Listening to History, New Jersey, 1987.

Meyer, Jessica, Men of War - Masculinity and the First World War in Britain, New York, 2009.

Oliver, W.H., The Story of New Zealand, London, 1960.

Olssen, Erik, \& Hickey, Maureen, Class and Occupation: The New Zealand Reality, Dunedin, 2005.

Olssen, Erik, Building the New World: work, politics and society in Caversham, 1880s1920s, Auckland, 1995.

Proctor, Tammy, On My Honour: Guides and Scouts in interwar Britain, Philadelphia, 2002.

Pugsley, Christopher, The ANZAC experience : New Zealand, Australia and Empire in the First World War, Auckland, 2004.

Pugsley, Christopher, Anzac : the New Zealanders at Gallipoli, Auckland, 1995.

Pugsley, Christopher, On the Fringe of Hell - New Zealanders and Military Discipline in the First World War, Auckland, 1991.

Reid, Fiona, Broken Men: shell shock, treatment and recovery in Britain, 1914-1930, London, 2010.

Sargent, Margaret J., Alcoholism as a Social Problem, St. Lucia, 1973.

Sinclair, Keith, A History of New Zealand, Reading, 1959. 
Sournia, Jean-Charles, A History of Alcoholism, Oxford, 1990.

Thomson, Alistair, 'Anzac Memories', Melbourne, 1994.

Ward, Chrissie (ed.), Dear Lizzie: a Kiwi soldier writes from the battlefields of World War One, Auckland, 2000.

Winter, Jay, Remembering war : the Great War between memory and history in the twentieth century, New Haven, 2006.

Wright, Matthew, Shattered glory: the New Zealand experience at Gallipoli and the Western Front, Auckland, 2010.

Yska, Redmer, Truth: The Rise and Fall of the People's Paper, Nelson, 2010.

\section{Journal Articles}

Brookes, Barbara, Shame and its Histories in the Twentieth Century', Journal of New Zealand Studies, No.9, 2010, pp.37-54.

Christoffel, Paul , 'Prohibition and the Myth of 1919', New Zealand Journal of History, vol.42, Is.2, 2008, pp.154-175.

Hanna, Martha, 'A Republic of Letters: The Epistolary Tradition in France during World War I', American Historical Review, Vol. 108, No. 5, 2003, pp.1338-1361.

Haugh, Susan, 'The Hill of Health: Aspects of Community at the Waipiata Tuberculosis Sanatorium, 1923-1961' in Health and History, Vol. 11, No.2, 2009, pp.1-20.

Johnson, Murray, "Promises and Pineapples": Post-First World War Soldier Settlement at Beerburrum, Queensland, 1916-1929', in Australian Journal of Politics and History, Vol.51, No.4, 2005, pp.496-512.

Leese, Peter, 'Shell shock: traumatic neurosis and the British soldiers of the First World War', The Journal of Modern History, Vol. 76, No. 4, 2004, pp. 955-956.

Lyons, Martyn, 'French Soldiers and their Correspondence: Towards a History of Writing Practices in the First World War', French History, Vol. 17, Issue 1, 2003, pp.7995.

Meyer, Jessica, "Not Septimus Now': wives of disabled veterans and cultural memory of the First World War in Britain', Women's History Review, Vol.13, No.1, 2004, pp.117137.

Neale, Kerry, "Without the Faces of Men"': the Return of Facially Disfigured Veterans from the Great War', When The Soldiers Return: November 2007 Conference Proceedings, Brisbane: University of Queensland, School of History, Philosophy, Religion and Classics, 2009, pp.114-120. 
Nelson, Elizabeth, 'Victims of War - The First World War, Returned Soldiers, and Understandings of Domestic Violence in Australia', Journal of Women's History, Vol.19, No.4, 2007, pp.83-106.

Rost, Allan, 'World War I soldier settlement: Government attempts and some private contributions', in Journal of the Royal Australian Historical Society, Vol. 94, Part 1, 2009 pp.38-56.

Weaver, John and Wright, David, 'Shell Shock and the Politics of Asylum Committal in New Zealand, 1916-22', Health and History, Vol.7, No.1, 2005, pp.17-40.

Worthy, Scott, 'A Debt of Honour: New Zealanders' First Anzac Days', New Zealand Journal of History, Vol.36, No.2, 2002, pp.185-200.

\section{Chapters in Edited Collections}

Brooking, Tom, 'Economic Transformation', in Geoffery Rice (ed.), The Oxford History of New Zealand, 2nd edition, Auckland, 1992, pp.230-253.

Clarke, Stephen, 'Return, Repatriation, Remembrance and the Returned Soldiers' Association 1916-22, in John Crawford \& Ian McGibbon (eds.), New Zealand's Great War, Auckland, 2007, pp.157-180.

Fairburn, Miles, 'The Farmers Take Over (1912-1930), in Keith Sinclair (ed.), The Oxford Illustrated History of New Zealand, Auckland, 1990, pp.185-210.

Hucker, Graham, 'The Armistice: Responses, Understandings and Meanings for a Rural Region', in John Crawford \& Ian McGibbon (eds.), New Zealand's Great War, Auckland, 2007, pp.569-582.

Lyttleton, Judith, Park, Julie, Bryder, Linda, 'The End of a Plague? Tuberculosis in New Zealand' in Ann Herring and Alan C. Swedlund (eds.) Plagues and epidemics : infected spaces past and present, New York, pp.119-136/

Noymer, Andrew, 'Epidemics and Time: Influenza and Tuberculosis during and after the 1918-1919 Pandemic', in Ann Herring and Alan C. Swedlund (eds.) Plagues and epidemics : infected spaces past and present, New York, pp.137-152.

Olssen, Erik, 'Working Gender, Gendering Work', in Barbara Brookes, Annabel Cooper, \& Robin Law (eds.), Sites of Gender: women, men and modernity in Southern Dunedin, 1890-1939, Auckland, 2003, pp.50-90.

Roche, Michael, 'Empire, Duty and Land' in Lindsay Proudfood and Michael Roche (eds.) (Dis)Placing Empire - Renegotiating British Colonial Geographies, Hampshire, 2005, pp.135-153

Sutherland, Beth, 'Family Life', in Beth Sutherland (ed.), My Dear Chick - A New Zealand Love Story 1911-1948, Masterton, 2008, p.233-262. 


\section{Unpublished Theses}

Boston, Peter J., "'The Bacillus of Work": Masculinity and the Rehabilitation of Disabled Soldiers in Dunedin 1919-1939', Hons thesis, Otago University, 1997.

Clarkson, Coralie, 'How Soldiers' Reactions to Death and Bereavement and the Horrors of War Were Portrayed Through Letters and Diaries', Honours Thesis, Victoria University, 2009.

Gould, Ashley, 'Proof of Gratitude? Soldier Land Settlement in New Zealand After World War I', PhD, Massey University, 1992.

Hucker, Graham, 'The Rural Home Front: A New Zealand Region and the Great War', PhD, Massey, 2006.

Parsons, Gwen, "The Many Derelicts of the War'? Great War Veterans and Repatriation in Dunedin and Ashburton, 1918-1928', PhD, Otago University, 2008.

Tennant, Margaret, 'Matrons With A Mission: Women's Organisations in New Zealand 1893-1915' MA thesis, Massey University, 1976.

Walker, Elizabeth, "The Living Death': the repatriation experience of New Zealand's wounded Great War servicemen', MA thesis, Victoria University, 2011.

Wynd, Michael ,'So the end has come- I shall see you all again': demobilising the New Zealand Expeditionary Force, November 1918-September 1919, MA Thesis, Massey University, 2006. 